Evaluation of Dust-Related

Health Hazards Associated

with Air Coring at G-Tunnel,

Nevada Test Site
B. J. Skaggs
L. W. Ortiz
D. J. Burton
B. L. Isom
E. A. Vigil 


\section{CONTENTS}

APPENDICES
FIGURES
TABLES
EXECUTIVE SUMMARY
ABSTRACT

1. Introduction_____ 2

1.1. Purpose

1.2. Scope

1.3. Objective

2. Current Regulations ___ _ 3

3. Description Of Work___ 3

3.0.1. Overview _ 3

4. Project Approach 3

4.1 Bulk Analysis (Task 1) _ _ 3

4.1.1. Background (Task 1)

4.1.2. Introduction (Task 1)

4.1.3. Materials And Methods (Task 1) ___ 5

4.1.4. Results (Task 1) _ 10

4.1.4.1. SEM 10

4.1.4.2. EDX 10

4.1.5. Bulk Analysis Conclusions (Task 1) _

4.2. Evaluation of Dust Collection Equipment (Task 2) ___ 11

4.2.1. Methods (Task 2) ___ 11

4.2.2. Emission Sources

4.2.3. Pretest And On-Site Evaluation Of Dust Control Equipment (Task 2) ___ 11

4.2.3.1. Background _ 11

4.2.4. Emission And Exposure Controls (Task 2) ___ 12

4.2.4.1. Findings _ 13

4.2.4.2. Dust Collection Equipment Conclusions (Task 3)___

4.3. Field Sampling (Task 3) ___ 14

4.3.1. Quality Assurance Procedures (Task 3) __

4.3.2. Equipment (Task 3) _ _ 17

4.3.2.1. SKC And Dupont Alpha 1 Personal Sampling Pumps ___

4.3.2.2. Air-Particulate Membrane Filters___ 17

4.3.2.3. Cascade Impactors ___

4.3.3. Data, Analytical Procedures, And Results

4.3.3.1. Polyvinylchloride (PVC) Membrane Filters ___

4.3.3.1.1. Gravimetric Or Total Dust Analysis _- 17

4.3.3.1.2. Respirable Mass And Crystalline Silica ___

4.3.3.1.3. Crystalline Silica Analysis _ 19

4.3.3.2. Mixed Cellulose Ester Membranes (MCEF) _ 22

4.3.3.2.1. Phase Contrast Microscopy _ 22 22

4.3.3.3. Nuclepore Polycarbonate Membranes ___ 26

4.3.3.4. Scanning Electron Microscopy (SEM) And Energy Dispersive X-Ray (EDX) Analysis

4.3.3.5. Andersen Cascade Impactors, Model 2000 MARK II _

4.3.3.5.1. Respirable Size Analysis By Cascade Impactors ___ _ 34

4.3.3.5.2. Conclusions From The Impactor Data___ 38 
5. On-Site Observations

6. Results And Conclusions For G-Tunnel Prototype Air Coring

7. Recommendations For Exploratory Shaft Facility At

Yucca Mountain (Task 4) 


\section{APPENDICES}

A. Estimates of Expected Expostre Concentration To Drill Dust ___ 44

B. Atias Copco and Collector Efficiency Literature _ 48

C. Detailed Procedurss ___ 52

D-1. Gravimetric Sample Analytical Data____ 53

D-2. Silica Sample Analytical Data__ 56

D-3. Fiber Sample Analytical Data__ 62

D-4. PIXE Sample Analytical Data__ 67

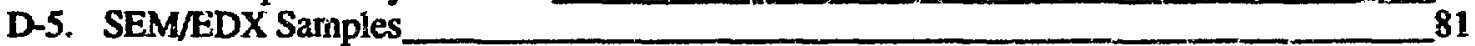

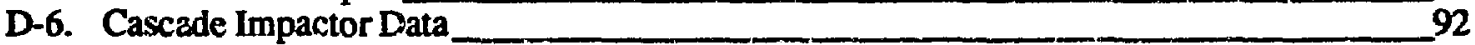

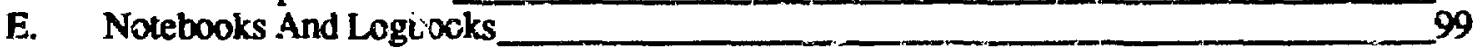

\section{FIGURES}

1. SEM Photomicrograph And EDX Spectrum: Pine Valley Erionite Bulk Sample

2. SEM Phorcmicrograph And EDX Spectrum: Pine Valley

Erionite Milled Sample

3. SEM Photorichograph Anâ EDX Spectrum: ESS - Erionite Fracture Coating

Scraped From Yucca Mountain Core Sample UE-25a \#1

4. SEM Photomicrograph And EDX Spectrum: ESS-1 Mordenite USW G-4 $1788.7-1789.9 \mathrm{ft}$

5. Exhaust Ventilatior A: Face

6a. Demoristration Drift Location Of Air Core Hole \#1 (AC-1)

6b. Sketch Of AC-1 Area 15

7a. Laser Drift Location Of Air Core Hole \#2 (AC-2) ___ 16

7b. Sketch Of AC-2 Area

8. MSA Sampling Fump On $\mathrm{BCT}$

9. Calibration Of Testing Pumps With The Gilibrator

10. Sulfaset Anchoring Spider/Collar To Wall In Laser Drift_____ 26

11. SEM Photomicrograph And EDX Spectrum Of NP0071-2___ 32

12. SEM Photomicrograph And EDX Spectrum Of NPO072-1___ 33

13. SEM Photomicrograph Of NP0014 At $5000 \mathrm{x}$

14. Investigator Preparing Impactor Filters ___ 35

15. Cascade Impactor And Vacuum Pump In Demonstration Drift ___ _

16a. Log Mobility Graph Of Sample Dm-SA Compared To Computer Results ___ _ 37

16b. Computer Program Resuits of Sample DM-SA ___ 37

17. Personnel In AC-1 Are Wearing PAPRs And Air-Monitoring Equipment ___ 39 


\section{TABLES}

I. ACGIH TLV And Biologicai Expostne Indices For 1987-88 ___ 3

I. Occupational Health And Sar ty Administrasicn Fegulations ___ 4

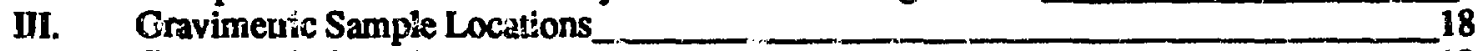

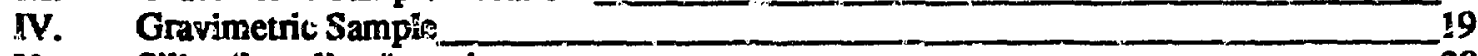

v. Silica Sampling Locations____ _ 20

VI. Crystalline Silica Report___ 21

VII. Bulk Silica Samples _ _ 22

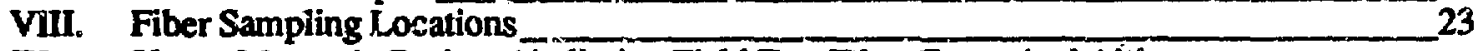

IX. Yucca Mountain Project Air Coring Field Test Fiber Count And Aibome Concentration Data ________ 24

X. PIXE Sampling Locations____ -

XI. Whole-Roct Chemical Analyses of Tuff Samples From G-Tunnel ___ 28

XII. Trace Element Hazani Analysis_____ 29

XIII. SEM/EDX Sampling Locations ___

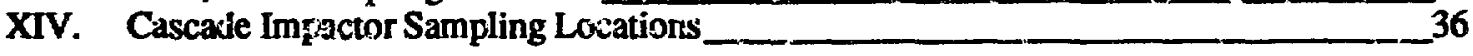




\section{EXECUTIVE SUMMARY}

An industrial hygiene study evaluated the health hazards associated with dust resulting from an air coring technical feasibility test performed by Los Alamos National Laboratory in G-Tunnel on the Nevada Test Site for the Yucca Mountain Project funded by the U. S. Department of Energy (DOE). This study was divided into four tasks.

\section{TASK 1 - BULK ANALYSIS}

One erionite and one mordenite bulk mineral sample from Yucca Mountain and one commercial natural erionite sample were examined by scanning electron microscopy (SEM) and energy dispersive $x$ ray (EDX) analysis. Two of the three samples contained significant quantities of microscopic fibers and fiber bundles. The third sample (the Yucca Mountain erionite) was amorphous with very few discernible fibers. EDX analysis of each sample indicated the common presence of aluminum, silicon, potassium, and calcium as major compositional elements, but the respective spectra were so similar that they were indistinguishable from each other. It was concluded that $X$-ray diffraction analysis (XRDA) is also necessary for proper identification/quantification of erionite and mordenite. SEM should be used for morphology, EDX used for elemental composition, and XRDA used for positive crystal structure identification and quantification.

\section{TASK 2 - DUST COLLECTION EQUIPMENT EVALUATION}

An evaluation of the proposed dust control equipment for the dry drilling equipment was conducted by use of the available manufacturer's technical literature, user experience, and regulatory agency experience. We attempted to identify potential emission sources and to quantify (where possible) emission rates, and we suggested potential emission/exposure controls. Based on available data on silica content, type, and particle size, and on proposed air coring (dry drilling) operations, it was estimated that allowable exposures to silica-containing dust could range from 0.07 to $1.5 \mathrm{mg} / \mathrm{m}^{3}$ (total dust) at the drilling sites. We concluded that actual airbome concentrations of dust might approach or exceed these values during nomal operations. Therefore, the project management was prepared to control emissions and exposures during prototype air coring. Emission controls were provided where feasible; employees were trained to use air-purifying respirators, which they were fit with and which they wore, and work practices were developed to minimize emissions and personal exposures. Examples of emission controls were the addition of an exhaust ventilation duct from the collar/drill stem area and a second duct from the top of the dust collector for fugitive dust control.

\section{TASK 3 - FIELD SAMPLING}

During March and April 1988, 112 personal and area air-particulate membrane filter samples and 14 cascade impactor sets (10 filters each) were collected as the prototype air coring of hole AC-1 (cored in Demonstration Drift) and hole AC-2 (cored in Laser Drift) progressed. Most of the modifications were made to the dust collection system during AC-1.

Gravimetric sample analysis indicated that the total dust concentrations for AC-1 ranged from $0.27-3.12 \mathrm{mg} / \mathrm{m}^{3}$ (average $=1.36 \mathrm{mg} / \mathrm{m}^{3}$ ) to $0.16-0.5 \mathrm{mg} / \mathrm{m}^{3}$ (average $=0.35 \mathrm{mg} / \mathrm{m}^{3}$ ) for AC-2, a significant decrease. (The background for both drilling sites was $0.05 \mathrm{mg} / \mathrm{m}^{3}$ ).

Determination of the respirable mass and $x$-ray diffraction of quartz, cristobalite, and tridymite was made by a contract laboratory. The respirable dust range was $0.32-2.74 \mathrm{mg} / \mathrm{m}^{3}$ (average $=1.02 \mathrm{mg} / \mathrm{m}^{3}$ ) for $A C-1$ and $0.17-0.43 \mathrm{mg}^{3} \mathrm{~m}^{3}$ (average $=0.27 \mathrm{mg} / \mathrm{m}^{3}$ ) for AC-2. Again, a reduction in dust was seen for AC-2 when cempared with AC-1. No cristobalite or tridymite was detected on any sample. One sample contained measurable quartz $(0.04 \mathrm{mg})$. The laboratory reported quarz on four other samples, but the quantity was within the lower limit of detection and quantification of the analytical instrumentation. 
The calculated quartz time weighted averages (TWA) were below the American Conference of Govermmental Industrial Hygienists (ACGIH) threshold limit value (TLV) for quartz (TLV/TWA $=0.1$ $\mathrm{mg} / \mathrm{m}^{3}$ ) because of the short durations of the drilling operations. If these operations were performed for 8 hours at the observed dust levels, the allowable 8-hour TLVs could be exceeded. Silica analysis of one AC-1 bulk sample and one AC-2 bulk indicated 6.8\% quartz detected for the AC-1 sample and $11.0 \%$ for the AC-2 sample. (No cristobalite or tridymite was detected in these samples.)

Phase contrast microscopic analysis of collected samples indicated few fibers. No fiber was identified as a zeolite; however $\mathrm{CaSO}_{4}$ fibers were detected and identified. Sulfaset, a plaster-of-paris $\left(\mathrm{CaSO}_{4}\right)$-based packing mud was used to stablize the collar/spider to the Laser Drift face. The collection/detection of these fibers (not considered a health hazard because of the low concentration) demonstrates that the monitoring/analytical techniques used can detect fibrous-shaped particles at very low concentrations $\left(<0.05\right.$ fibers $\left./ \mathrm{cm}^{3}\right)$.

Photon induced $x$-ray emission analysis determined the elemental content of 10 samples and the two bulk samples previously discussed. Comparison of the elemental analysis with published whole rock chemical analysis showed a similar distribution of elements. When the trace element compositions were compared with ACGIH TLVs for these elements, it was concluded that there is no trace element hazard to area personnel.

Forty-three membrane filter air samples were examined by SEM/EDX. All particles observed were either nonfibrous particles or loosely bound agglomerates of nonfibrous particles. No fibers were detected. The bulk samples were also examined by SEM/EDX, and again no fibers were detected.

Andersen cascade impactors were used for collecting particles and quantifying the particle size distribution of the airbome material and total dust concentration in the range of $0.4-10 \mu \mathrm{m}$ aerodynamic diameter. The data indicated the AC-1 particle size distribution was 1.9 to $3.8 \mu \mathrm{m}$ mass median aerodynamic diameter (MMAD), standard deviation ( $S D=2.5-3.8)$. The gross concentration average was $3.37 \mathrm{mg} / \mathrm{m}^{3}$ for $A C-1$. The particle size distribution for $\mathrm{AC}-2$ was 0.97 to $1.47 \mu \mathrm{m}$ MMAD (SD $=6.06$ 9.8). The gross cocentration average was $0.57 \mathrm{mg} / \mathrm{m}^{3}$.

A sign.ficant number of the particles were smaller than $0.4 \mu \mathrm{m}$, as shown by the high percentages of total amount of the aerosol collected on the final filters. A large portion of the aerosol was identified as diesel exhaust particles, normally in the $0.25-0.26-\mathrm{Im}$ size range, which would not impact on any of the Andersen impactor stages. The AC-2 samples showed a smaller particle size than those from AC-1.

The diesel "mucker" (without an exhaust scrubber) operated more frequently in the vicinity of AC2 than near AC-1. The lower dust levels observed in AC-2 are attributed to the progressively implemented dust control measures designed into the dust collection system. Most (86-90\%) of the gross concentration is within the respirable size range. Respiratory protection should be available in case of an emission excursion.

\section{RESULTS AND CONCLUSIONS}

(1) SEM/EDX and XRDA are required for specific identification/quantification of fibrous zeolites.

(2) A supplementary exhaust system is required.

(3) Crystalline silica analysis detected no cristobalite or tridymite. One quartz positive (0.04 $\mathrm{mg} / \mathrm{m}^{3}$ ) was detected, and four quantities $\left[0.02 \mathrm{mg} / \mathrm{m}^{3}\right]$ were within the level of detection and quantification for the analytical instrumentation. Calculated TWAs were lower than the ACGIH quartz TLVITWA.

(4) Zeolite fibers were not detected in AC-1 and AC-2 airbome particulate samples collected during air coring. 
(5) The dust control system was effective in the sampled configuration.

(6) Diesel exhaust particulates from vehicles working in the G-Tunnel area were detected.

\section{TASK 4 - RECOMMENDATIONS FOR EXPLORATORY SHAFT FACILITY AT YUCCA MOUNTAIN}

Based on the findings presented in this report, we recommend that the following be implemented in future drilling activities.

(1) General dilution ventilation and local exhaust ventilation must be provided to the drilling site.

(2) Air supplied to the drill hole must be balanced at all times with the dust collection equipment.

(3) Area employees (workers and investigators) must be fitted for, provided with, and trained to wear air-purifying respirators for emergency situations.

(4) Dust control equipment should be properly maintained and in operation during any dry, or air, drilling activity.

(5) All potential emission sources should be identified in advance of drilling, and emission control strategies developed.

(6) Vehicle exhaust emissions should be kept as low as reasonably achievable.

(7) Safe operation procedures should be developed and implemented.

(8) Drilling operating should adhere to existing health and safety requirements applicable to the site.

(9) The potential hazard (based on geologic mapping) to the personnel working in the Yucca Mountain area mandates that similar sampling and analysis for fibrous zeolites, especially mordenite, be performed during drilling at Yucca Mountain to determine the hazards and appropriate protection for area personnel.

(10) Animal inhalation studies with mordenite (identified as being one of the primary zeolites in the Yucca Mountain tuffs) should be conducted to determine the biological effects of this fibrous zeolite. 


\title{
EVALUATION OF DUST-RELATED HEALTH \\ HAZARDS ASSOCIATED WITH AIR CORING AT G-TUNNEL, NEVADA TEST SITE
}

\author{
by \\ B. J. Skaggs, L. W. Ortiz, D. J. Burton, \\ B. L. Isom, and E. A. Vigil
}

\begin{abstract}
The Yucca Mountain Project (formerly the Nevada Nuclear Waste Storage Investigations Project) was established by the U.S. Department of Energy (DOE) to evaluate the potential for storing high-level radioactive wastes in geologic formations near the Nevada Test Site (NTS). Before in situ tests at Yucca Mountain, field-scale tests are being conducted at NTS, where similar welded tuffs with properties and in situ stress states are located. Hydrologists recommended that drilling or coring in support of characterization tests be performed dry because of concerns that liquid drilling fluids could perturb the hydrology.

Dry drilling, or air coring, presents a concern about health protection for the drilling personnel. Water normally used as a circulating fluid also reduces air contaminants generated by the drilling equipment. Extensive core drilling and characterization of the Yucca Mountain mineralogy indicate two potential health hazards to persons exposed to dust and fibers generated at the site. First, the rock generally has a high silica content. Achieving the current occupational exposure levels for crystalline silica during dry drilling requires excelient dust control. Second, natural zeolites are also abundant. Some zeolites such as mordenite and erionite are fibrous, leading to concerns that inhalation of zeolitic dusts containing such fibers may result in asbestos-like lung diseases, including mesothelioma. Very little is known about the hazards of dusts containing fibrous zeolites, especially mordenite, which has been identified as "mappable" in the Yucca Mountain tuffs. However, limited epidemiologic and toxicologic studies performed with erionite indicate that fibrous zeolites may be of concern.
\end{abstract}

An industrial hygiene study (IH) was conducted as part of an air coring technical feasibility test performed by the Los Alamos National Laboratory. The IH study 1) found the potential for exposures to airborne silica and nuisance dusts to be within regulatory requirements and 2) determined the commercial dust control equipment monitored to be effective, as tested, when used in conjunction with a good area ventilation system and sound industrial hygiene practices. Fibrous zeolites were not detected in the drilling of those two holes. Recommendations for the Yucen Mountain studies are 1) dust collection and control equipment equivalent or superior to that monitored must be used for any dry (air) drilling activity and must be used with good general dilution ventilation and local exhaust ventilation provided on major emission sources; 2) good industrial hygiene work practices must be implemented, including monitoring any area where zeolitic fibers are suspect; and 3) a study should be conducted to determine the biological effects of the fibrous zeolite, mordenite. 


\section{INRRODUCTION}

\subsection{PURPOSE}

The Yucca Mountain Project (YMP) (formerly the Nevada Nuclear Waste Storage Investigations Project) was established to evaluate the potential for storing high-level radioactive wastes in geologic formations on or adjacent to the Nevada Test Site (NTS). Yucca Mountain has been chosen as the primary evaluation site, and site characterization is planned. Field-scale tests are being conducted at G-Tunnel, located on the NTS some $40 \mathrm{~km}$ from Yucca Mountain, before initiating in situ tesis in the Exploratory Shaft Facility (ESF) at Yucca Mountain. Welded tuffs with properties and in situ stress states similar to that of Yucca Mountain tuffs are located in the G-Tunnel Underground Facility.

U.S. Geological Survey hydrologists have recommended to all principal investigators that dilling or coring in support of their tests be performed dry (that is, with air as the circulating fluid) if any possibility exists that liquid drilling fluids could perturb the hydrology. ${ }^{1}$ Hydrologists and other investigators are aware that air coring technology currently is not well developed for underground mining. The Prototype Air Coring Test conducted by Los Alamos National Laboratory addresses the technical feasibility of air coring short, horizontal holes in fractured welded tuff; identifies related problem areas; and provides holes for subsequent prototype tests. ${ }^{2}$

Dry drilling (air coring) preserts a health protection concem because water nomally used as a circulating fluid also reduces air contaminants generated by drilling. This study provides data on the airbome concentrations of dusts and fibers from air coring at G-Tunnel.

Work to date at Yucca Mountain has included extensive core drilling and characterization of site mineralogy. These data indicate two areas of concem abcut potential health hazards to persons exposed to dust and fibers generated from rock at the site. First, the rock generally has high percentages of silica ranging from $20 \%$ to $>70 \%$. ${ }^{3}$ The health hazards of inhalating crystalline silica have been recognized fo: more than 50 years. Clinical symptoms from crystalline silica exposure are not evident until many years later. Excellent dust control procedures will be required to achieve the current occupational exposure levels during dry drilling of rock containing high levels of silica. Therefore, the adequacy of controls must be addressed before drilling operations start at Yucca Mountain.

Second, natural zeolites (predominately clineptilolite, mordenite, and heulandite) are also abundant at Yucca Mountain. Some zones contain as much as $90 \%$ natural zeolites. ${ }^{3}$ The zeolites. mordenite and erionite are fibrous, leading to concems about inhalation that result in asbestos-like lung diseases. Erionite has been identified as a fracture-lining mineral in a sample from only one borehole; mordenite, however, is reported to be abundant and can be mapped between many drill holes and at many depths. ${ }^{3}$ Very litule is known about the hazards associated with dusts containing fibrous zeolites, especially mordenite, but limited animal toxicology studies performed with erionite indicale that it may have far greater potential for causing lung tumors, including malignant mesothelioma, than does asbestos (causing almost 100\% tumor incidence in rats, compared with about 20\% for asbestos). ${ }^{4-6}$ Mesothelioma is usually associated only with asbestos exposure. Epidemiologic studies of a village in Turkey where airbome erionite is present also indicate high incidence of lung diseases. ${ }^{7-9}$ Because these diseases will not manifest themselves for many years after exposure, the adequacy of engineering controls must be evaluated before drilling begins at Yucca Mountain.

\subsection{SCOPE}

This study was designed to (1) identify and evaluate the potential for exposures to airborme silica, nuisance dusts, and fibrous zeolites and (2) evaluate the effectiveness of the commercial dust control equipment attached to the drilling apparatus.

\subsection{OBJECTIVE}

The objective of the study was to evaluate the potential exposure of drilling workers and scientific investigators to airtome dusts and fibers so that protective measures (engineering controls, administrative controls, and personnel profective equipment) can be incorporated into the drilling and scientific/experimental project at the ESF. 


\section{CURRENT REgULATIONS}

The current American Conference of Govemmental Industrial Hygienists (ACGIH) threshold limit value/time weighted average (TLV/TWA) and Occupational Safety and Health Administration (OSHA) regulations for the potential hazards encountered in this study are listed in Tables $I$ and II. Currently there is no regulation or TLV for zeolite fibers; however, studies indicate that some of these fibers are considerably more toxic than asbestos fibers.

\section{DESCRIPTION OF WORK}

3.0.1. OVERVIEW. Evaluation of potential exposure to airborne dusts and fibers is a subpart of, "The Prototype Air Coring of Short, Horizontal Holes in Fractured Welded Tuff." These efforts are in support of the YMP.

Early evaluations of core samples at both Yucca Mountain and G-Tunnel indicate two areas of concem about potential health hazards: high levels of silica and significant levels of various $z e-$ olites within the rock. Effective dust control systems will be required to minimize worker exposure during prototype drilling in G-Tunnel and must be required during site characterization at Yucca Mountain.

Evaluation of the potential health hazards and controls was divided into four tasks:

BULK ANALYSIS (TASK 1). Bulk samples of core material from G-Tunnel and Yucca Mountain were analyzed to assess the potential for producing airbome fibers from the various zeolites. This analysis resulted in a preliminary evaluation of the potential exposure associated with such airbome materials.

EVALUATION OF DUST COLLECTION EQUIPMENT (TASK 2). Dust control/collection equipment was evaluated by a review of the manufacturer's technical literature, user experience, and regulatory agency experience to define the probable level of exiciciency expected with such air-cleaning systems.

FIELD SAMPLING (TASK 3). A field study was performed during the prototype air coring pro-
TABLE I

\section{ACGIH TLV AND BIOLOGICAL EXPOSURE INDICES FOR 1987-88}

\begin{tabular}{|c|c|}
\hline Substance & TLV/TWA \\
\hline $\begin{array}{l}\text { Silica, } \mathrm{SiO}_{2} \\
\text { Quartz } \\
\text { Cristobalite } \\
\text { Tridymite }\end{array}$ & $\begin{array}{l}0.1 \mathrm{mg} / \mathrm{m}^{3}{ }_{3} \text {,espirable dust } \\
0.05 \mathrm{mg} / \mathrm{m}^{3} \text {, respirable dust } \\
0.05 \mathrm{mg} / \mathrm{m}^{3} \text {, respirable dust }\end{array}$ \\
\hline $\begin{array}{l}\text { Nuisance Particulates } \\
\text { (Most Dusts) }\end{array}$ & $10 \mathrm{mg} / \mathrm{m}^{3}$ total dust \\
\hline $\begin{array}{l}\text { Asbestos } \\
\text { Amosite } \\
\text { Chrysotile } \\
\text { Crocidolite } \\
\text { Other Forms }\end{array}$ & $\begin{array}{l}0.5 \text { fiber } / \mathrm{cm}^{3}, \mathrm{~A} 1 \\
2 \text { fiber } / \mathrm{cm}^{3}, \mathrm{~A} 1 \\
0.2 \text { fiber } / \mathrm{cm}^{3}, \mathrm{~A} 1 \\
2.0 \text { fiber } / \mathrm{cm}^{3}, \mathrm{~A} 1\end{array}$ \\
\hline
\end{tabular}

ject at G-Tunnel to evaluate the potentiai for exposure to airbome crystalline silica and zeolite fibers and to determine the effectiveness of the dry drilling dust control equipment in operation.

RECOMMENDATIONS FOR YUCCA MOUNTAIN (TASK 4). Recommendations for operating procedures and health/safety requirements to be implemented during ESF studies at Yucca Mountain were developed on the basis of the nther tasks.

\section{PROJECT APPROACH}

\subsection{BULK ANALYSIS (TASK 1)}

4.1.1. BACKGROUND (TASK 1). Extensive core drilling and mineralogic characterizations of Yucca Mountain indicate that the rock contains significant quantities of crystallire silica and natural zeolites. 3 The hazands posed by inhalation of crystailine silica are well recognized. Little is known, however, about possible hazands associated with inhaling zeolitic dusts. Certain zeolites (erionite and mordenite) are known to be present in the geologic 
TABLE II

OCCUPATIONAL HEALTH AND SAFETY ADMINISTRATION REGULATIONS

SUBSTANCE

29 CFR 1910.1000. (3c.) (7-1-87 Edition) Table Z-3;

Crystalline:

Quartz (Respirable)

Quartz (Total Dust)

Cristobalite:

Tridymite:

Inert or Nuisance Dust:

Respirable

Total Dust

29 CFR 1910.1001 Asbestos et al.

Action Level

Permissible Exposure

Limit (PEL)

Zeolite Fibers for quartz.
15

50 $\mathrm{mg} / \mathrm{m}^{3}$

$10 \mathrm{mg} / \mathrm{m}^{3 \mathrm{a}}$

$\mathrm{\% SiO}_{2}+2$

$30 \mathrm{mg} / \mathrm{m}^{3}$

$\approx \mathrm{SiO}_{2}+2$

Use $1 / 2$ the value calculated from the count or mass formulae

Use $1 / 2$ the value calculated from the formulae for quartz.

$5 \mathrm{mig} / \mathrm{m}^{3}$

$15 \mathrm{mg} / \mathrm{m}^{3}$
$0.1 \mathrm{f}^{\mathrm{cm}} \mathrm{cm}^{3} \mathrm{TWA}$

$0.2 \mathrm{f} / \mathrm{cm}^{3}$ TWA

(determined by Phase

Contrast Microscopy

or better)

No Regulation or TLV

$\bar{a}$ Conclusion and $\mathrm{SiO}_{2}$ determined from specific size selection.

An employee's exposure to any material listed in Table Z-3 of 29 Code of the Federal Regulations (CFR) 1910.1000, in any 8-hour work shift of a 40-hour work week, shall not exceed the 8-hour TWA given for that material in the table. 
formations of Yucca Mountain. Mordenite content at Yucca Mountain is reported to be sufficient for geologic mapping, ${ }^{3}$ whereas the presence of erionite is considered rare and has been confirmed only once, as a fracture coating. ${ }^{3}$ Both of these zeolites evoke special concem because of their unique fibrous morphology. Erionite has been implicated as the etiologic agent of concern in producing asbestos-like lung diseases in both man and animals. ${ }^{4-9}$

Animal toxicology studies conducted with erionite indicate that it may have a greater potential for causing primary lung tumors (including mesothelioma) than does asbestos. Some investigators feel that this potential for tumor production is related to fiber "respirability" and microscopic fibrous morphology. ${ }^{10-11}$ No toxicologic or epidemiologic information conceming health effects of inhaled mordenite has been found in a search of the literature. Dusts produced from both of these fibrous zeolites are of concem because of compositional/morphological similarities and implied resultant health effects related to exposures to other naturally occurring siliceous fibrous minerals of similar sizes (namely the various types of asbestos).

\subsubsection{INTRODUCTION (TASK 1). As part} of our participation in this project, we used existing LANL, Industrial Hygiene Group (HSE-5), capabilities to recognize, identify, detect, and measure the occurrence of erionite/mordenite in anticipated field-collected airbome material.

This capability was limited to sample cvaluation using scanning electron microscopy (SEM) for morphology assessment and energy dispersive $\mathrm{x}$-ray (EDX) analysis for elemental composition determinations. This section summarizes the findings of these efforts performed before the field sampling task began.

\subsubsection{MATERIALS AND METHODS} (TASK 1). Exploratory fiber assessment (SEM/EDX) experiments have been limited to the examination of three bulk zeolitic materials.

Two bulk mineral samples (one erionite and one mordenite) were obtained from the Geological/Geochemistry Group (ESS-1) at LANL, and one natural erionite mineral sample was purchased from a commercial mineral supply house (Minerals Unlimited, Ridgecrest, Califomia). Both samples obtained from ESS-1 were small chips ( $2 \mathrm{mg})$ of material originating from Yucca Mountain core ma- terials. The commercial erionite was labeled "Erionite, Pine Valley, Eureka County, Nevada." Both mineral samples obtained from ESS-1 had been characterized by $x$-iä; diffraction analysis (XRDA) and were confirmed as (1) erionite (ESS-1 fracture coating scraped from 1296.2-1296.8 ft, UE25a *1) and (2) mordenite (ESS-1, USW G-4, banded layer sample 1788.7-1788.9). The commercial (Pine Valley, Nevada) erionite sample was confirmed as $95+\%$ erionite by XRDA (ESS-1) and defined as a suitable reference material for subsequent HSE-5 erionite/fiber assessment comparison experiments.

Each sample was mounted on a carbon planchet, was carbon coated, and was examined with an American Metals Research (AMR) model 1000 scanning electron microscope at 20,50,100,200, $500,1000,2000,5000$, and 10000 magnification to determine the locale and visibility of fibers and to select appropriate fields for photographs, fiber con. tent assessment, and EDX analysis. Sections of each sample were photographed at various magnifications. Examples of the microscopic appearance of each sample are shown in Figs. 1-4. Also shown in Figs. 1-4 are EDX spectra obtained from selected

areas of each sample. The commerciai sample of erionite (Pine Valley, Nevada) was examined by SEM/EDX in two different states: bulk and milled. Each form is illustrated in Figs. 1 and 2.

Figure 1 illustrates an SEM view taken at $1000 \mathrm{x}$ and an EDX spectrum obtained from the bulk sample of the Pine Valley (PV) erionite. Figure 2 illustrates similar SEM/EDX information obtained from a milled sample of the same PV erionite. EDX spectra obtained from both milled and unmilled samples are essentially identical, but comparative SEM photomicrographs illustrate that milling of the bulk sample decreases fiber size (diameter and length) and enhances the number of free fibers present in the sample.

Figure 3 shows SEM/EDX data obtained from an ESS-1 sample labeled as erionite (scraped from Yusca Mountain core-sample fracture coating taken at 1296.2 to $1296.8 \mathrm{ft}$ ). This sample was a small amorphous chip $(-2 \times 3 \times 1 \mathrm{~mm}$ nonfibrous with an off-white waxy luster) with no fibers detected at magnifications of 20 to $10000 \mathrm{x}$. This finding is inconsistent with the reported fibrous habit of erionite. ${ }^{12}$ The EDX spectrum obtained from this nonfibrous ESS-1 bulk core material is very similar to the commercial (fibrous) PV erionite sample. 

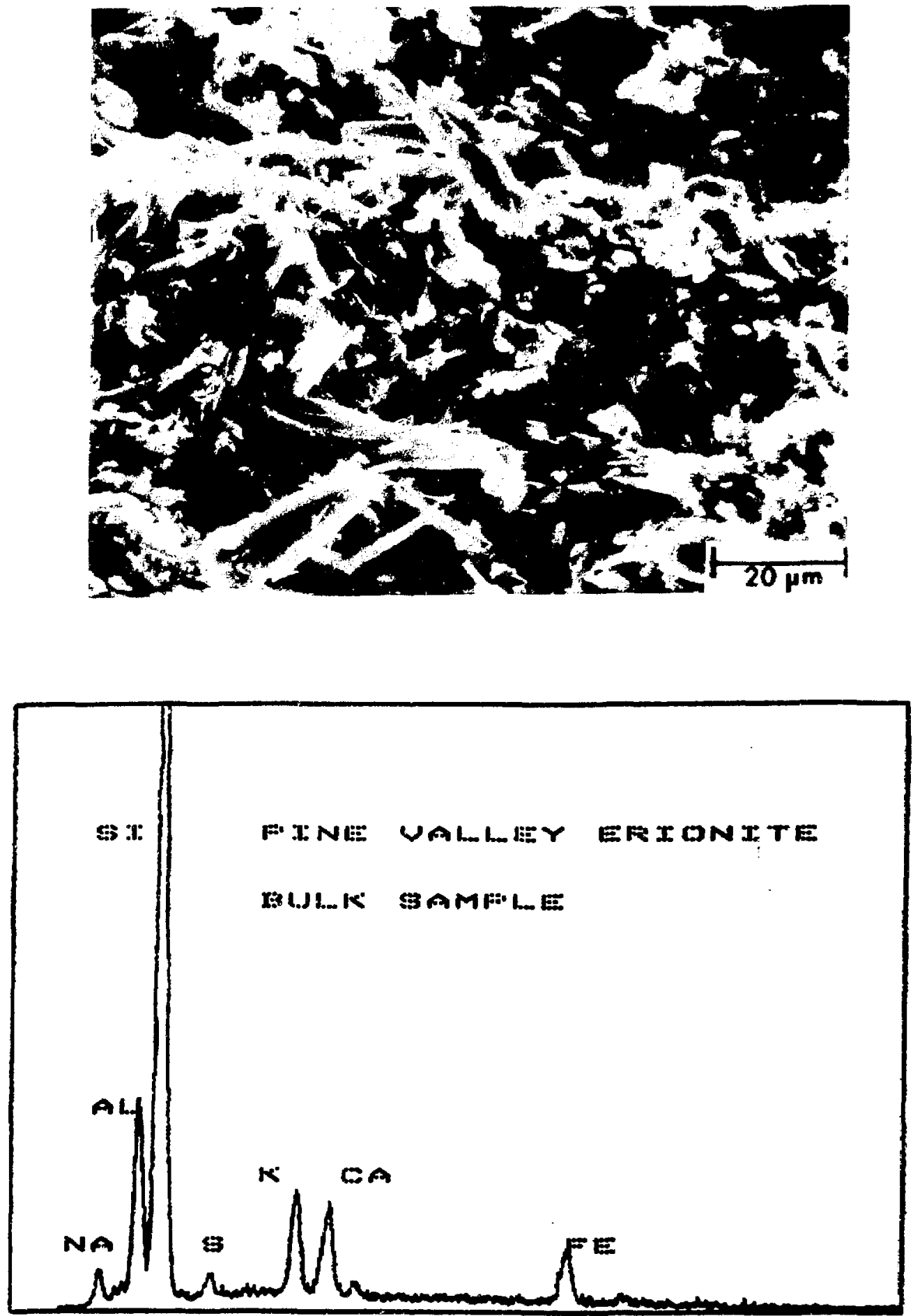

Figure 1. SEM Photomicrograph (1000x) and EDX Spectrum:

Pine Valkey erionite-Bulk Sample. 

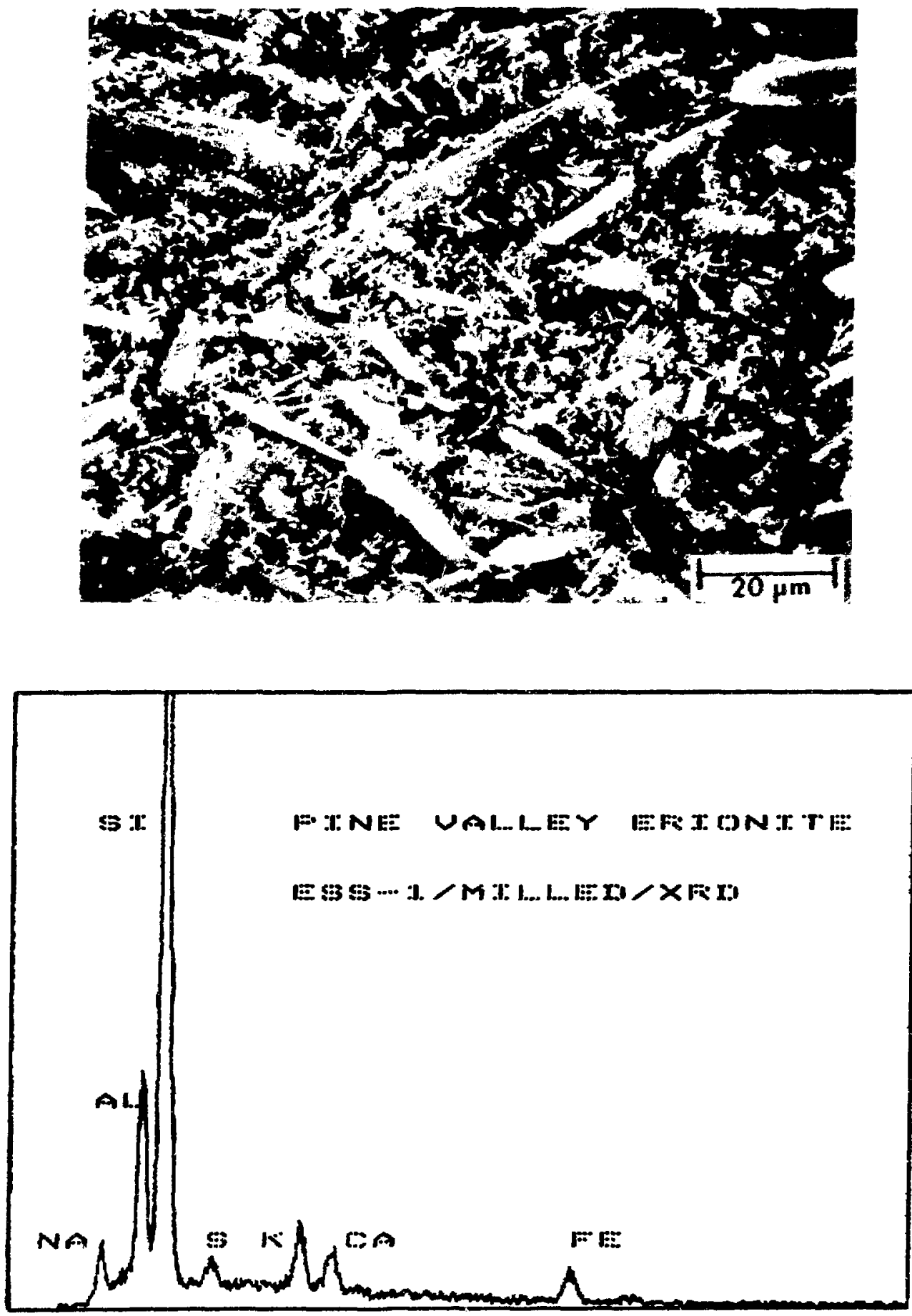

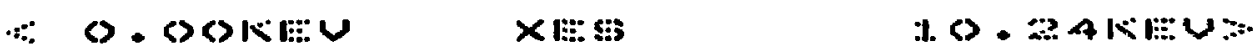

Figure 2. SEM Photomicrograph (1000x) and EDX Spectrum:

Pine Valley erionite-Milled Sample. 

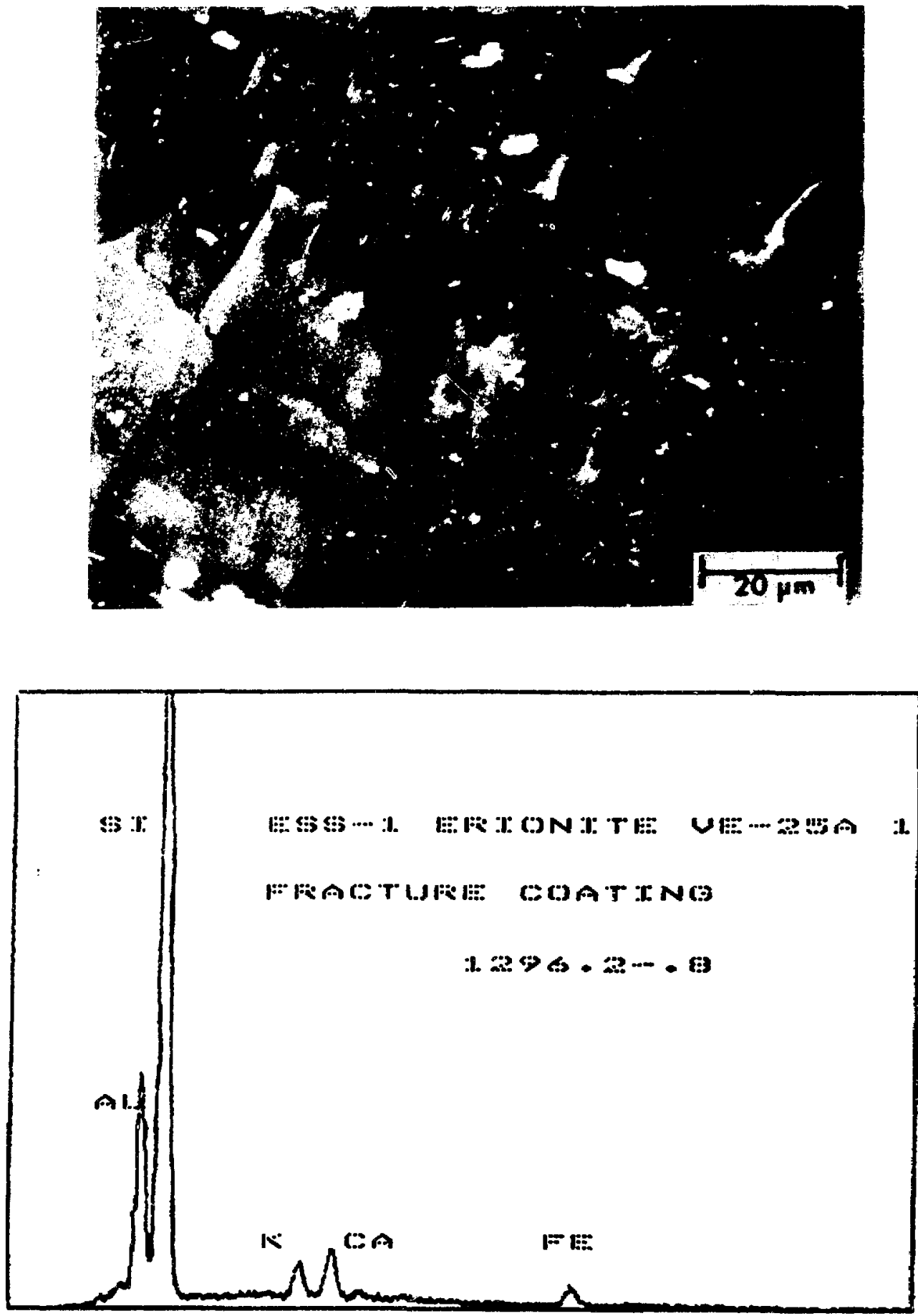

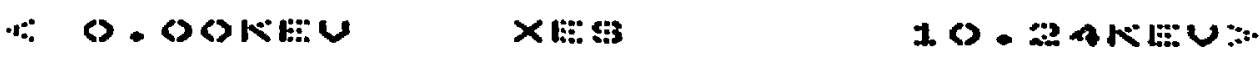

Figure 3. SEM Photomicrograph (1000x) and EDX Spectrum: ESS-I erionire-fracture coating scraped from Yucca Moundain core sample UE-2Sa $\# I(1296.2-1296.8 \mathrm{ft})$. 

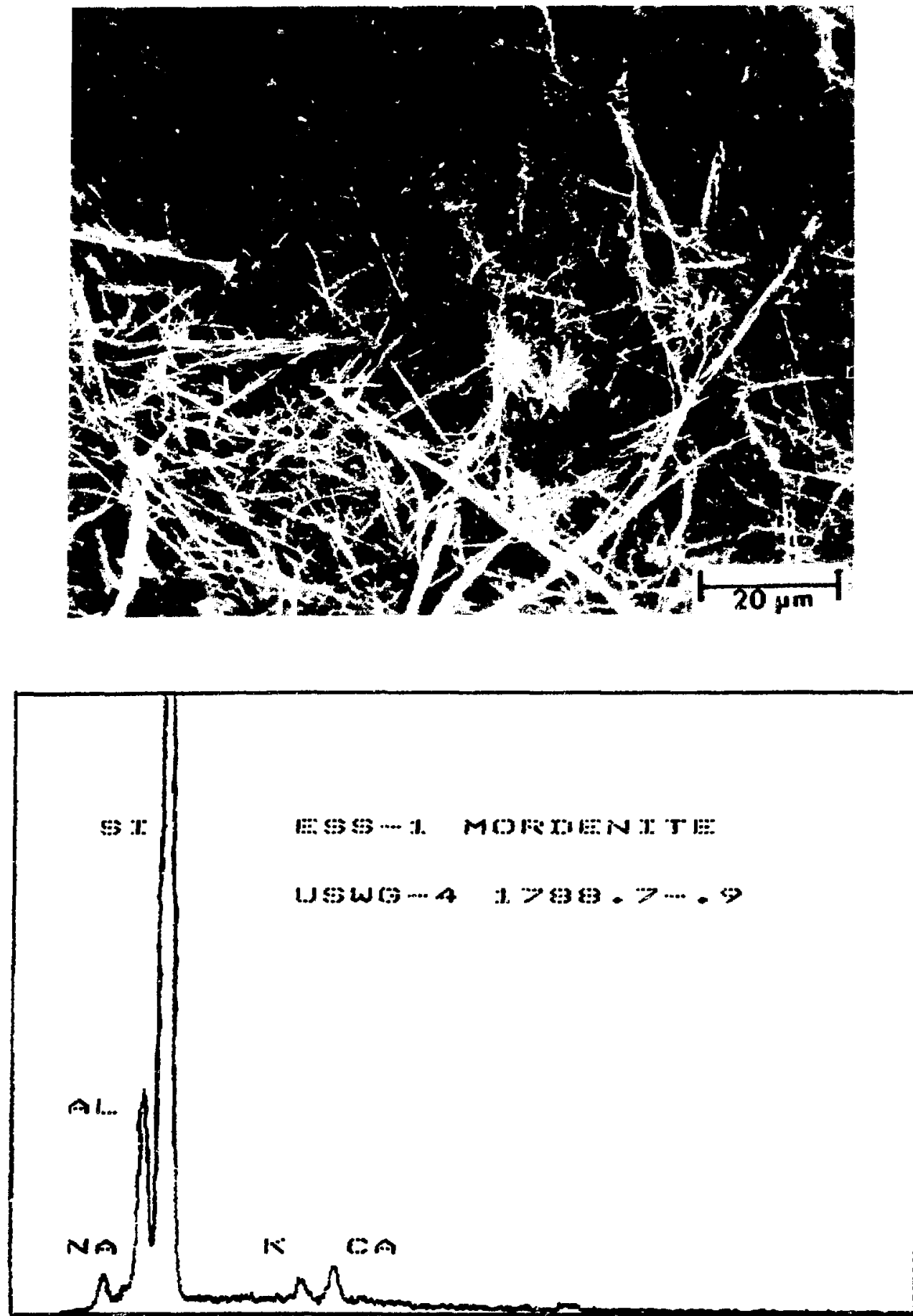

$\because \quad 6 . \cos \quad \times 1 \%$

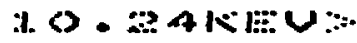

Figure 4. SEM Photomicrograph (1000x) and EDX Spectrum:

ESS-1 mordenite USW G-41788.7-1788.9 ft. 
Figure 4 illustrates SEM/EDX information obtained from examination of the single sample of mordenite (ESS-1 USW G-4 1788.7-1788.9 ft). The SEM photomicrograph of this sample shows the classical long, thin fibrous structure of this material. The EDX spectrum of this mordenite sample is very similar to the respective spectra of the two erionite samples examined in this comparative evaluation.

\subsubsection{RESULTS (TASK 1).}

4.1.4.1. SEM. Examination of all three samples at various magnifications by SEM indicated that swo of the three samples contained significant quantities of microscopic fibers and fiber bundles. The PV crionite and Yucca Mountain mordenite contained many free fibers, as weil as fiber bundles, aggregates, and amorphous material. The fibrous materiai constituting the PV erionite sample has the general appearance of microscopic wood splinters of variable size with nonuniform lengths and diameters. The single Yucca Mountain mordenite sample contained many symmetrical, uniform-diameter microscopic fibers of various lengths (similar in microscopic appearance to bundles of fine-diameter fibrous glass). Fiber diameters of this ESS-1 mordenite sample range from -0.08 to $3.0 \mu \mathrm{m}$. Very few free fibers were detected in this sample. The single sample of Yucca Mountain erionite was amorphous, with very few discemible fibers.

4.1.4.2. EDX. EDX analysis of each sample (Yucca Mountain erionite, Yucca Mountain mordenite, and PV erionite) indicates the common presence of aluminum, silicon, potassium, and calcium as major compositional elements in all samples. Of more concem is the finding that the respective spectra are so similar that they are indistinguishable from each other. This limited EDX comparison thus suggests that EDX cannot distinguish mordenite from erionite.

\subsubsection{BULK ANALYSIS CONCLUSIONS} (TASK 1).

(1) This SEM/EDX work is considered preliminary and limited in scope and effort. Orly three locally available reference samples (two erionite and one mordenite) were examined for this program, with mixed resuits.

(2) Two of three reference zeolite samples examined by SEM contained fre fibers, Ininiature fiber aggregates, and fiber bundles of a size considered potentially "respirable"

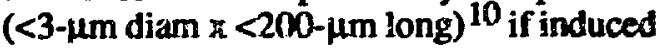
into an aitome state.

(3) Milling of the commercial PV srionite decreased fiber size (both diameter and length) and increased the number of free fibers in the sample.

(4) One reference erionite sample (Yucca Mountain fracture coating scraped from 1296.2-1296.8 ft, UE-25a \#1) isad no detectable fibers when examined by SEM at magnifications up to $10000 x$. This finding is not consistent with the crystal habit of erionite, 11 and the inconsistency needs further investigation.

(5) EDX analysis indicated the common presence of aluminum, silicon, potassium, and calcium, and traces of iron and sodium in all three zeolite reference samples.

(6) EDX analysis alone does not provide sufficient elemental/compositional information. to distinguish erionite from mordenite. XRDA is needed for specific mineral identification/confirmation.

(7) A minimum combination of SEM/EDX/ XRDA is necessary for proper identification/quantification of the two fibrous minerals of concern. SEM is necessary for morphology, EDX for elemental composition, and XRDA for positive crystal structure identification and şuantification.

(8) Analyticai efforts should focus on the $25-$ sessment of mordenite as the principal fibrous zeolite of concem at the repository site because of the relative abundance of this material at Yucca Mountain, NTS, in comparison with the documented rare occurrence of erionite. 3 


\subsection{EVALUATION OF DUST COLLECTION EQUIPMENT (TASK 2)}

Based on available data on silica content, type, and particle size and on proposed dry drilling operations, it was estimated that allowable exposures to silica-containing dust could range from 0.07 to $1.5 \mathrm{mg} / \mathrm{m}^{3}$ (total dust) at the drilling sites, depending on the silica content of the dust. We concluded that actual airborne concentrations of dust might approach or exceed these values during normal operations, based on preliminary evaluations conducted as part of this work. (See Appendix A for calculations.) Therefore, project management prepared to control emissions and exposures during drilling (e.g., emission controls were provided where feasible, employees were trained and fitted for air-purifying respirators, and work practice training was provided to minimize emissions anò personal exposures).

4.2.1. METHODS (TASK 2). Dust collection equipment was evaluated in two stages: a pretest evaluation of proposed control equipment and an on-site observation of controls actually used. The findings of the pretest evaluation were reported in an interim report ${ }^{13}$ and are summarized in paragraph 4.2.3.

At the test site, observations were conducted during prototype drilling to identify emission sources, characterize emissions, and qualitatively evaluate control measures. For the most part, our preliminary findings ald estimates were confirmed at the site during testing.

4.2.2. EMISSION SOURCES. As part of the study, we attempted to identify potential emission sources, quantify (where possible) emission rates, and suggest potential emission/exposure controls.

Potential emission sources are:

- fugitive emissions from dust collection equipment (hoses, boot, fittings, and so forth);

- fugitive emissions from the dust collector itself;

- process emissions from vibrating equipment, moving equipment, and drilling operations;
- fugitive emissions from dust reentrainment (air movement, moving equipment, people moving about);

- background sources of airtome dust from other tunnel operations; and

- direct emissions from contaminated clothing and equipment.

The cnly fugitive emission quantified before drilling was that from the dust collector and the collection equipment. However, special efforts were made to reduce all emissions and to minimize employee exposures through respirator use, work practices, and equipment maintenance.

4.2.3. PRETEST AND ON-SITE EVALUATION OF DUST CONTROL EQUIPMENT (TASK 2).

4.2.3.1. Background. Dust control for the prototype drilling operations at G-Tunnel consisted of a commercial dust collector attached to the drilling equipment.

Before on-site testing, available literature from the manufacturer, users, and regulatory agencies was reviewed to estimate literature was the level of control expected under actual work conditions. No experimental or test activities were performed before or during on-site testing.

The pretest review considered the following factors, noted below, with the constraint that data and/or information were not available in many cases:

- published efficiency of the bag filter media for respirable size dusts;

- first-stage efficiency for dust size, concentrations expected to be produced, and health significance;

- air-flow/pressure-drop characteristics of the system blower, which together with the information obtained in 4.2.4., indicate the operational requirements for filter cake removal; 
- effectiveness of cake removal procedures, based on published technical literature (by the manufacturer and others), which indicates operational requirements and potential problems;

- airkloth ratio (ratio of the volume of gas to the filter area) and how this relates to probable filter performance;

- design capture velocity and collection efficiency:

- seal design characteristics; and

- filtrate removal procedures and the potential for secondary sources of particle release.

Fotential sources of information included:

- manufacturer of the equipment proposed for use,

- users of the systems proposed for G-Tunnel and the ESF,

- the project drilling consultant,

- U.S. Bureau of Mines and Mine Safety and Health Administration,

- available literature, and

- unpublished research reports.

4.2.4. EMISSION AND EXPOSURE CONTROLS (TASK 2). Generally, emission and exposure controls fall into three categories:

- those that control at the emission source (local exhaust ventilation, process controls, equipment modifications, work practice controls, wet methods, enclosure, and housekeeping);

- those that interrupt or reduce the path of the contaminant as it travels from the emission site to the breathing zone of employees (isolation of employee, dilution ventilation); and
- those that protect at the breathing zone (respirators, supplied air islands).

For prototype drilling, the following controls were used to minimize dust enissions ard exposures.

(1) A dust collector was installed on the dri" shaft exhausi systern.

(2) Local exhituit ventilasion was provided by use of dust collection collas or boot at the drill shaft. (See Fig. 5 for details.)

(3) A secondary duct was extended frow ite main duct to the area of the boot to control fugitive emissions from the boot.

(4) The exhaist air from the dust collector was ducted to the main exharst sysierr. (Altematively, a second filter could have been fitted to the outlet of the primary filter if sufficient static pressure had been available.)

(5) Employees were encouraged to use emission-reducing work practices (e.g., selecting appropriate drill speeds, placing equipment properly, controlling equipment, minimizing vibrations, keeping the area clean, not drilling during collection equipment malfunction, and so forth).

(6) Dilution ventilation was provided to maintain airborne concentrations of dust at acceptable levels.

(7) Respirators were provided and maintained.

(8) Rigorous maintenance of dust control equipment was emphasized.

(9) The number of people and the amount of machinery traffic in the area were limited.

Other dust emission controls that could have been used (but were not) include:

- dust suppression materials used on the tunnel floor (e.g., wet sawdust, sand, or other suitable material) and 


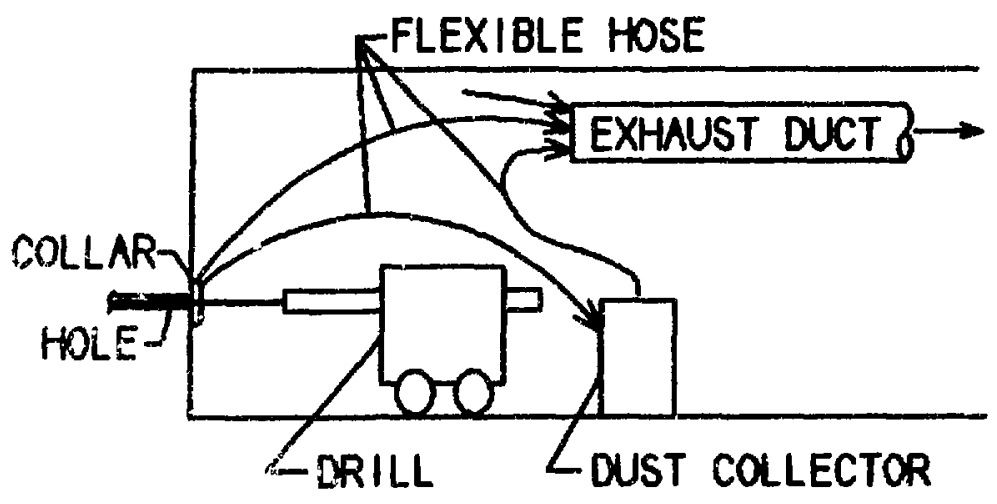

Figure S. Exhakst ventilation at face.

- housekeeping to remove settled dust from drilling and attendant equipment.

Because it is difficult to quantitatively characterize emission sources, it is also difficult to suggest which controls were most effective. Based on actual employee exposures measured during drilling, it appears that all controls were useful and important and should be used in any such drilling work in the future.

4.2.4.1. Findings. The prototype drilling project used an Atlas Copco dust collector, the DCT90. Appendix B presents the manufacturer's literature describing the equipment. Similar equipment is available from other manufacturers.

The dust collector was equipped with a twostage separator. The first stage was a baffledinertial separator capable of removing most of the large dust particles. The second stage was a bag or envelope-type fabric filter consisting of 18 filter bags. (Shaking the bag cleaned the unit)

Extensive inquiries were made in an attempt to establish the collection efficiency of the proposed equipment, but we had no success. Copco's literature claims filter efficiencies of "nearly $100 \%$ " for particles smaller than $5 \mu \mathrm{m}$ in diameter. Atlas Copco was asked to conduct efficiency tests. This information may be available sometime in the future, but it will represent efficiencies in laboratory crnditions, not those in actual use.

Collector emission calculations presented in Appendix A have assumed a high level of collection efficiency, $+99.5 \%$. This efficiency is consistent with that of the general type of collection equipment used. (See efficiency data published by Vandergrift, Stairmand, and American Air Filter Co., Inc., in Appendix B. These data suggest that inertial collectors in series with fabric filters provide collection efficiencies of $95.0-99.9 \%$ by weight.)

\subsubsection{Dust Collection Equipment} Conclusions (Task 2). On the basis of available information and our on-site observations, we conclude the following about the collection system.

(1) We do not know the exact collection efficiency of the air cleaner, but it was assumed to approach 99.5\% during favorable operating conditions (basic data in Appendix B; drilling contractor's experience).

(2) The first-stage filter can remove 60\%-80\% of the dust reaching the collector (data in Appendix B). 
(3) The filter may quickly load up, requiring cleaning and maintenance on a regular basis, e.g., every $1.5 \mathrm{ft}$ of drilling during routine operations (on-site drilling experience).

(4) Any similar air cleaners should be required to provide the flow rates and static pressures required to operate the local exhaust system, i.e., DCT-90 exhausts up to $62 r$ acfm against 6-in. water gauge pressure.

(5) Testing of selected drilling equipment unier actual drilling conditions may be required to evaluate the suitability of the collection equipment for routine and ongoing drilling operations (on-site assessment).

(6) Cleaning of the collection equipment and disposal of the dust are labor intensive and require careful handling to avoid personnel exposure (on-site drilling experience).

(7) The close-capture design of the local exhaust hood (boot) provided a high degree of dusi control at the drill shaft. However, the boot requires maintenance and careful positioning (on-site drilling experience).

(8) A supplementary exhaust system is required 1) to remove emissions from the air cleaner, 2) to control fugitive emissions, and 3) to provide dilution ventilation to the area.

Additional obseryations made during prototype drilling are found in Section 5 . ON-SITE OBSERVATIONS.

\subsection{FIELD SAMPLING (TASK 3)}

Field air sampling was conducted during prototype air coring in G-Tunnel at NTS to (1) evaluate the potential worker exposure to crystalline silica and fibrous zeolites and (2) evaluate the effectiveness of the dry drilling dust-control equipment in operation. The evaluation of these potential hazards represents an extension of the nomal industrial hygiene support provided by Reynolds Electrical and Engineering Company (REECo) and constitutes a special hazard evaluation study. All activities were coordinated with REECo Industrial Hygiene.

The first air cored hole (AC-1) was drilled at the face of G-Tunnel's Demonstration Drift (Fig. 6). An electric Longyear 38 drill and an Atlas Copco DCT 9099504 were positioned at the AC-1 drill site. The DCT collar surrounded the drill stem and had an attached flexible hose (approximately 4in. diam and 16-ft long) that carried the cuttings and dust from the hole to the dust collector. The collar was mounted to the tunnel face by a three-legged apparatus (named the spider) with metal foot plates held in place by rock bolts. Pressurized air was injected into the hole through the drill to cool the bit and transport the cuttings out of the hole. Additional suction on the cuttings was provided by the DCT's venturi-designed ejector. The tunnel exhaust system at the AC-1 area consisted of a 20 in. duct, with an airilow of $7000 \mathrm{cfm}$, attached to the ceiling along the right side of the drift. The second air cored hole (AC-2) was drilled in the right wall (from the face) of G-Tunnel's Laser Drift (Fig. 7). The exhaust ventilation in Laser Drift was $6600 \mathrm{cfm}$.

Field air sampling included (1) obtaining and evaluating the applicability and limitations of REECo air sampling data collected during past GTunnel mining operations; (2) making all arrangements with REECo and other NTS organizations for performing the air-sampling task; (3) collecting the air samples during the air coring project; (4) analyzing samples and interpreting data; and (5) developing the evaluation report.

Two types of air samples were obtained: (1) personal samples, those collected with personal sampling pumps connected to a filter cassette placed on the lapel of the worker involved in drilling or experimental activities; and (2) area samples, those collected with sampling pumps with attached filter cassettes positioned in locations of interest, such as near the drill stem penetration of the drift wall or on the dust collector. Cascade impactor samples were coliected and were also considered area samples.

43.1. QUALITY ASSURANCE (QA) PROCEDURES (TASK 3). This study was classified as a YMP QA Level II study because it has direct bearing on the health of the workers involved in the prototype tests and potentially on the health of the Yucca Mountain workers. As a Level II study, the strict QA constraints required the development of detailed quality assurance procedures (DPs) for the 
Figure 6.

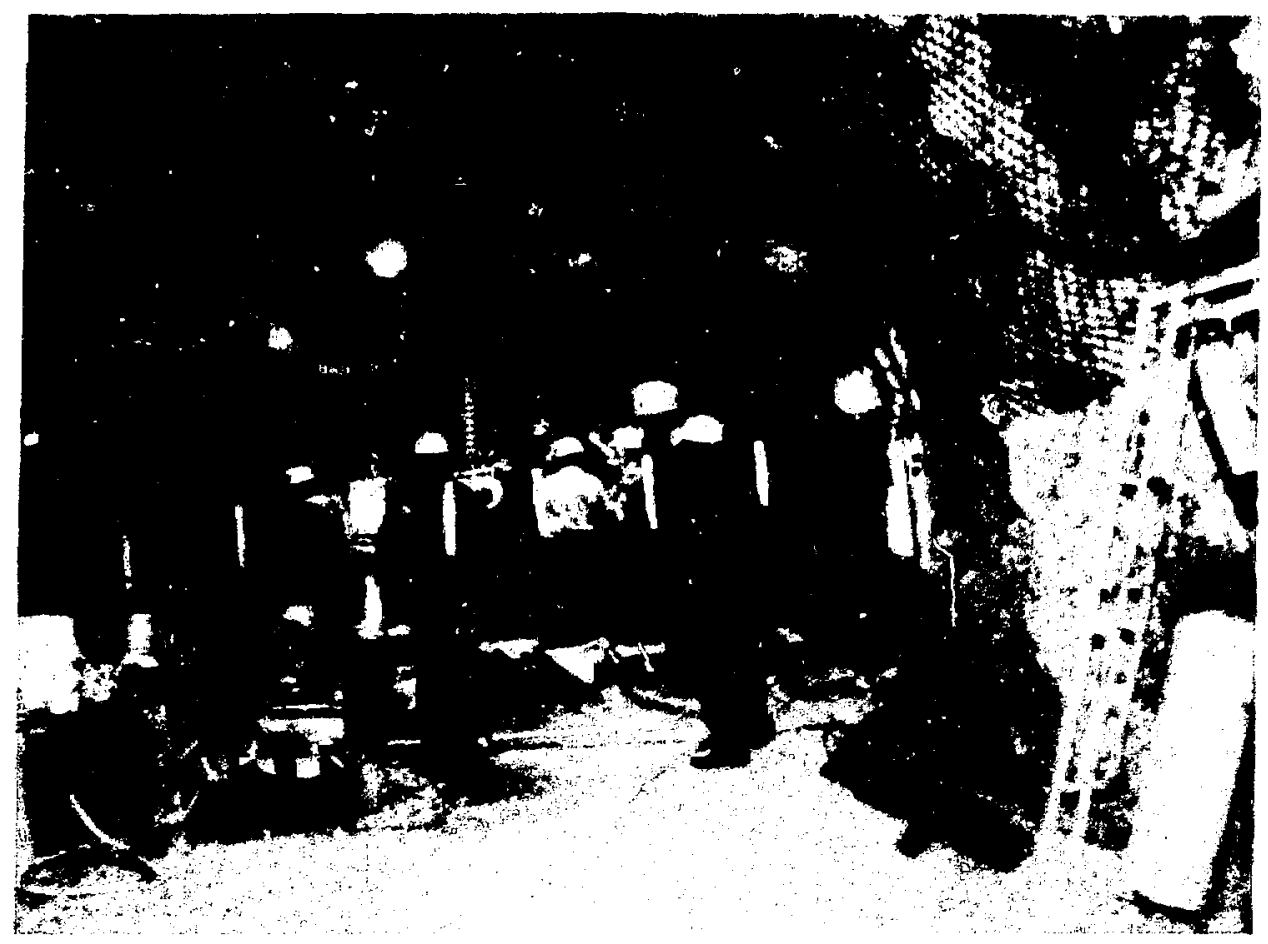

(a) Demonstration Drigh bcation of ar cere hale in (AC-1).

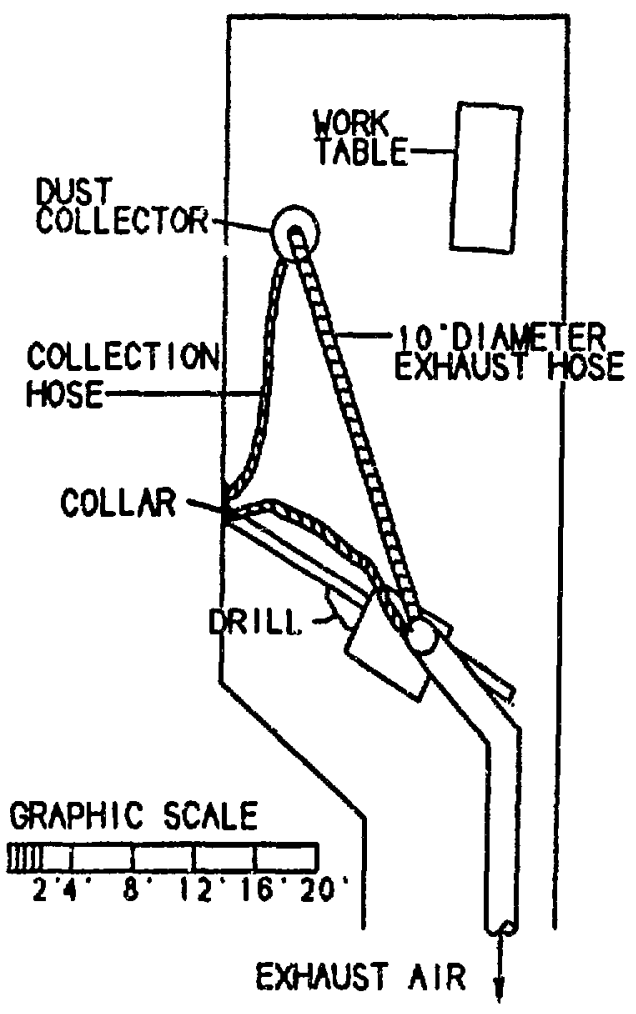

(b) Sketch of AC-1 area 
Frure 7.

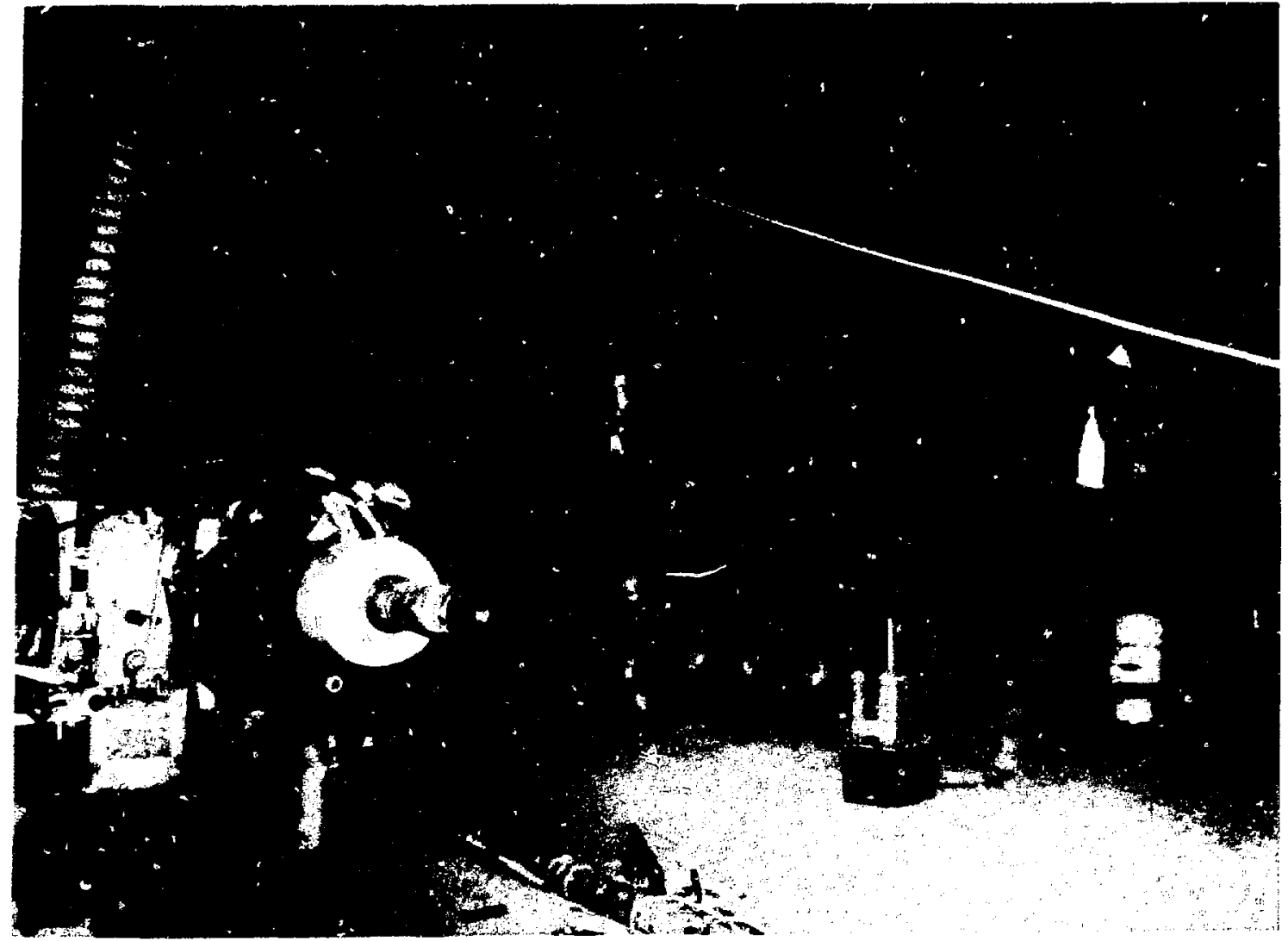

(a) Laser Drift beation of air cent hole 2 (AC-2).

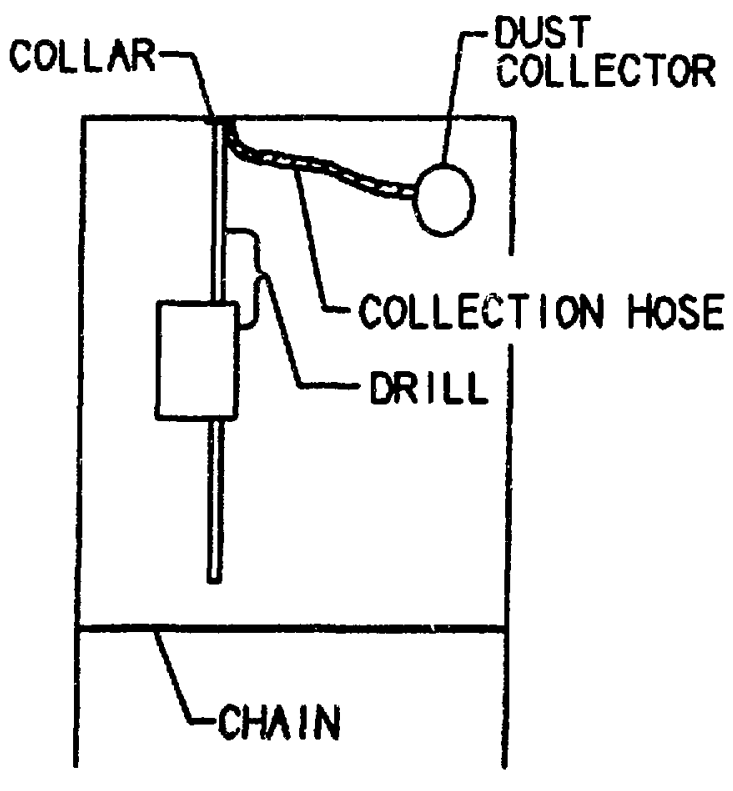

GRAPHIC SCALE

(b) Sketch of AC-2 aree.

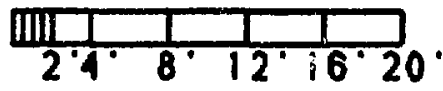


use of the sampling media, sampling equipment, and analytical procedures utilized in this task. Appendix C contains a list of the detailed procedures developed for this study. The LANL YMP (NNWSI) QA Manual ${ }^{14}$ contains an updated copy of each procedure and subsequent change orders.

\subsection{EQUIPMENT (TASK 3).}

\subsubsection{SKC and DuPont Alpha 1 persongl} semoline pumps. Personal sampling pumps were used to collect area and personal air particulate samples to be used in the evaluation. A personal sampling pump is a small $\left(-2.5 \mathrm{lb}, \sim 735 \mathrm{~cm}^{3}\right)$ vacuum pump powered by a rechargeable battery pack. A prepared membrane filter cassette is attached to the pump with a length of flexible tubing. The pump draws air through the membrane filter, collecting available particulate material from the air (Fig. 8). Detailed procedures were developed for preparation and use of these pumps during sampling at G-Tunnel.

A Gilian Gilibrater (an electronic bubble flowmeter), shown in Fig. 9, was used to calibrate each pump's airflow before and after each sampling period. The Gilibrator was calibrated by the LANL calibration laboratory, 15 and the following correction factor was provided by personnel of the LANL Statistics Group (A-1) for the Gilibrator flow tube (\#751-S) used in the pump calibrations at the G-tunnel preparation site. 16

Corrections for Gilibrator readings between

$$
\begin{aligned}
& 717.3 \mathrm{~cm}^{3} \leq y \leq 5748 \mathrm{~cm}^{3} \\
& \hat{x}=(y-48.16178) / 1.01204 . \\
& \text { Error }(1 \mathrm{SD})^{2}=0.976348 \mathrm{y}^{2} \mathrm{c}^{2} \mathrm{~h}-0.012638 \\
& (y-48.16178) \\
& +5.14758 \times 10^{-6}(y-48.16178)^{2}+13.217311 \text {, } \\
& \text { where } c=0.00875 y .
\end{aligned}
$$

Detailed procedures indicated that temperature and elevation corrections would be made according to the OSHA Field Operation Manual. 17 Temperature corrections were not necessary because the differential temperature between the preparation (calibration) site and sampling site was within the OSHA temperature limit.
Likewise, corrections for altitude differentials were not required because the 500 -ft elevation difference was never met as the preparation site was 6115-ft elevation and the Demonstration Drift and Laser Drift where the samples were collected were both at $-6205 \mathrm{ft}$.

4.3.2.2. Air Particulate Membrane Filters. Membrane filters were prepared and used as the air sampling collection media. The individual membrane was positioned (loaded) on top of a support pad in a disassembled cassette; the cassette was reassembled and closed tightly. Plastic tape was used to secure the cassette sections and was color coded to identify the membrane type within. A unique identification number was assigned to each membrane filter and was engraved on the exterior of the cassette.

43.23. Cascade Impactors. Andersen cascade impactors were used for collecting and quantifying the particle size distribution of the airbome particulate material and total dust concentration of 10 to 0.4- $\mu \mathrm{m}$ aerodynamic diameter.

\subsection{DATA, ANALYTICAL PROCE-} DURES, AND RESULTS (TASK 3). The field air particulate sampling was perfor ed during March and April 1988, as the air coring of AC-1 and AC-2 progressed. One hundred and twelve air particulate membrane filter samples and 14 cascade impactor sets (10 filters each) were collected. One unidentified (blind) blank was provided with each sample set submitted for analysis. Uniess stated otherwise, LANL Group HSE-5 used the methods listed in Appendix C (DPs) to perform the analyses described in this section.

4.3.3.1. Polyvinylchloride (PVC) Membrane Filters. PVC membranes ( $5-\mu \mathrm{m}$ pore size, $37-\mathrm{mm}$ diam) were used for (1) total dust measurement, (2) determination of the sespirable fraction, and (3) crystalline silica analysis.

433.1.1. Gravimetric or Total Dust ArrIysis. The 37-mm PVC membranes were desiccated, weighod, and loaded into three-piece styrene acrylonitrile air monitor cassettes, which were then sealed and engraved. At the G-Tunnel sampling site, the cassettes were attached to the sampling pumps in the open-face mode, and 


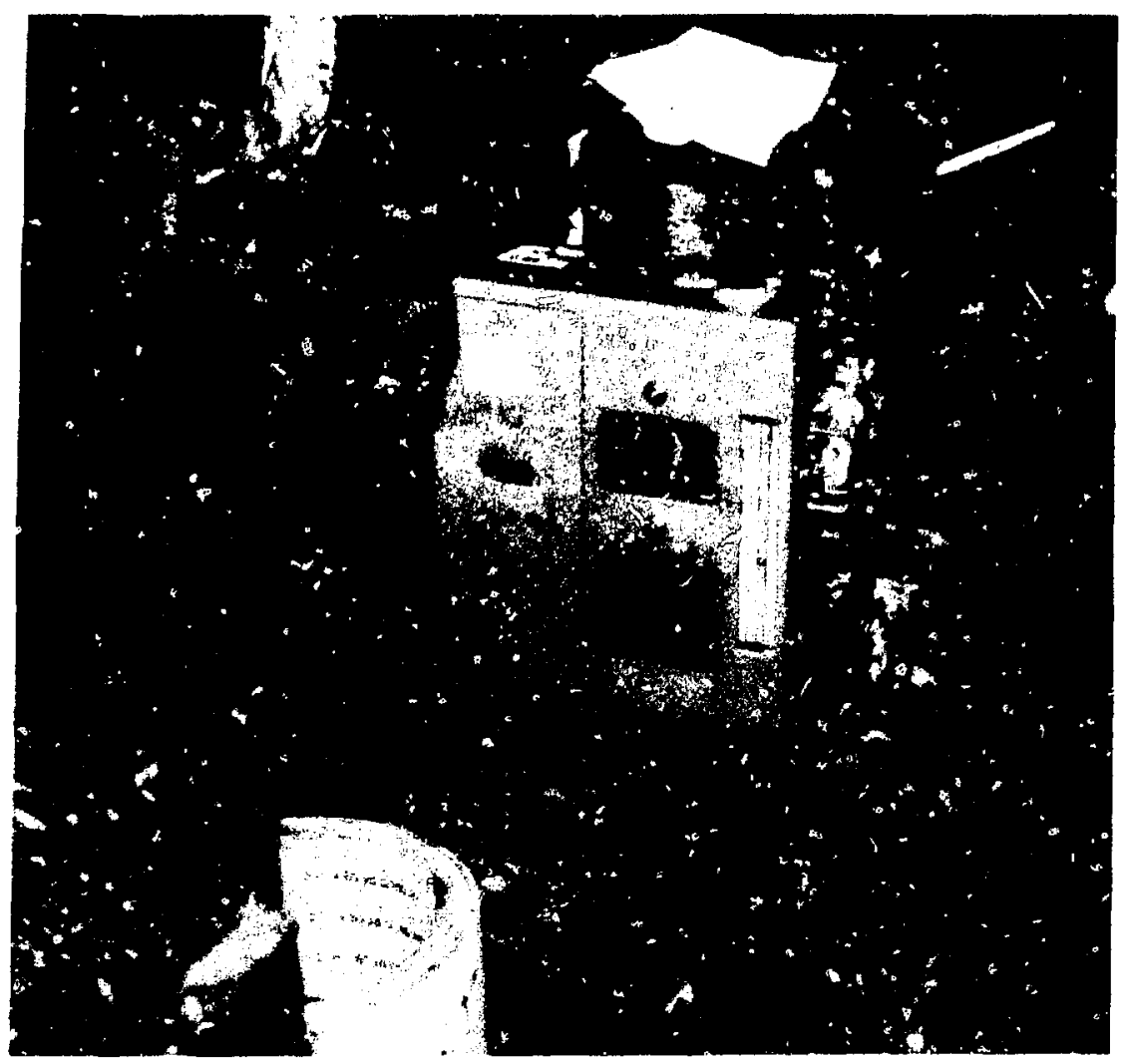

Figure 8. SKC Sampling Pump on DCT.

Figure 9. Calibration of testing pumps with the cilibrator.

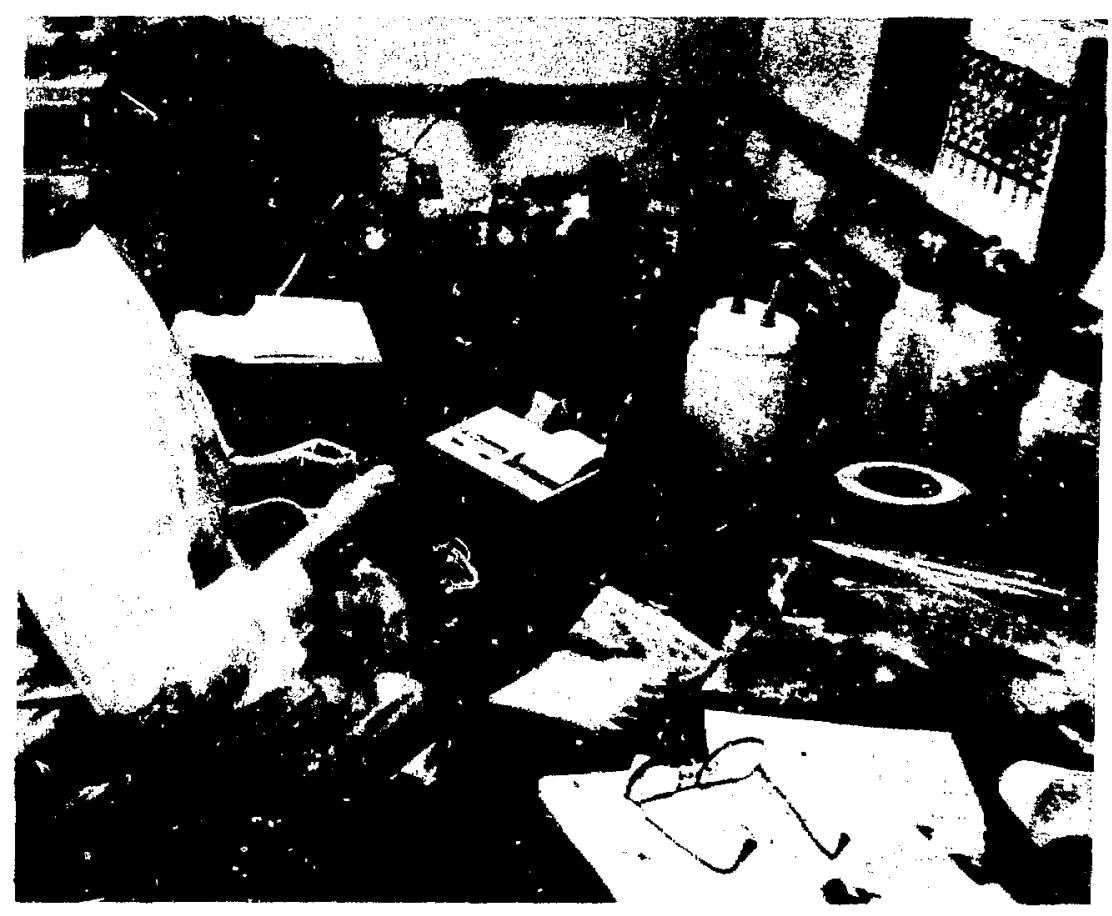


available air particulates were collected. After sampling, the cassettes were capped and sealed, then transported back to Los Alamos. The membranes were again desiccated and weighed to determine the total accumulation of air particulate material.

Table III lists the sampling date, core hole, and lacation of the samples during collection of the $\mathbf{1 0}$ gravimetric samples.

Table IV lists the gravimetric (total dust) concentrations calculated from weight gain and the sampling flow rates. Sample PV-3 provided the background concentrations $\left(0.05 \mathrm{mg} / \mathrm{m}^{3}\right)$ for core hole AC-1. The weight gain for AC-1 (Demonstration Drift) samples ranges from $0.27-3.12 \mathrm{mg} / \mathrm{m}^{3}$ (average $=1.36 \mathrm{mg} / \mathrm{m}^{3}$ ), with the largest concentrations seen during the modification of the dust collection system. During AC-2 (Laser Drift) air coring, the background concentration was also 0.65 $\mathrm{mg} / \mathrm{m}^{3}$ (PV-17), but the range was $0.16-0.5 \mathrm{mg} / \mathrm{m}^{3}$ (average $=0.35 \mathrm{mg} / \mathrm{m}^{3}$ ), a significant decrease. Complete gravimetric (PV) sample data for AC-1 and $\mathrm{AC}-2$ are located in Appendix D-1.
4.3.3.1.2. Respirable Mass and Crystalline Silica. Silica samples were collected on 5- $\mu \mathrm{m}$ pore size, 37-mm-diam PVC membrane filters. These filters were weighed, loaded into two-piece filter cassettes, sealed with shrink bands by DataChem (formerly Utah Biomedical Laboratory, Inc. of Salt Lake City, Utah), and then shipped to Los Alamos. Upon receipt, they were inscribed with the appropriate sample numbers.

At the G-Tunnel sample preparation site, the (filter-containing) cassettes were placed on clean $10-\mathrm{mm}$ nylon cyclones and attached by flexible tubing to personal sampling pumps calibrated at a nominal 1.7 liters/min. At the sampling site, each cyclone/cassette was positioned on a worker's lapel near the breathing zone. These samplers were wom by the REECo driller and the drilling helper (and sometimes by the LANL drilling consultant) because of their direct involvement in air coring operations. After collection, the cassettes were sealed and retumed to DataChem. The analytical laboratory personnel reweighed the membranes to determine the weight gain (respirable mass) and

TABLE III

GRAVIMETRIC SAMPLING LOCATIONS

\begin{tabular}{ccc}
\hline $\begin{array}{c}\text { Sample } \\
\text { Date }\end{array}$ & $\begin{array}{c}\text { Sample } \\
\text { No. }\end{array}$ & Sampling Location \\
\hline
\end{tabular}

AC-1

\begin{tabular}{|c|c|c|}
\hline $03 / 22 / 88$ & PV 3 & $\begin{array}{l}\text { BACKGROUND, right side: } 5 \mathrm{ft} \text { above floor and } 20 \mathrm{ft} \\
\text { above face }\end{array}$ \\
\hline $03 / 24 / 88$ & PV 5 & On Right wall, approximately $16 \mathrm{ft}$ from drill \\
\hline $03 / 30 / 8$ & PV 9 & Area sample at drill (left overnight) \\
\hline $03 / 30 / 88$ & PV 15 & Begin/Extensiometer Drift, inside curve, right side \\
\hline$B C$ & PV 6 & Right wall, approximately $16 \mathrm{ft}$ face, set for work shift \\
\hline $407 / 88$ & PV 13B & BLANK - PV samples \\
\hline
\end{tabular}

$\mathrm{AC}-2$

04/13/88 $\quad$ PV $17 \quad$ BACKGROUND, Rock bolt left of collar (spider)

04/14/88 PV $31 \quad$ Left wall by drill collar (spider)

04/14/88 PV 47 Hanging behind DCT

04/20/88 PV 36 Hanging on wire (middle of personnel area)

04/20/88 PV 22 Rock bolt between DCT and drill collar (spider)

$A C-1$ is first core hole (located in Demonstration Drift).

$A C-2$ is second core hole (located in Laser Drift). 
TABLE TV

GRAVIMETRIC SAMPLE DATA

\begin{tabular}{lccccc}
\hline $\begin{array}{c}\text { Sample } \\
\text { No. }\end{array}$ & $\begin{array}{c}\text { Sample } \\
\text { Date }\end{array}$ & $\begin{array}{c}\text { Total } \\
\text { Mass } \\
(\mu \mathrm{g})\end{array}$ & $\begin{array}{c}\text { Run Time } \\
(\mathrm{m})\end{array}$ & $\begin{array}{c}\text { Air } \\
\text { Volume } \\
\left(\mathrm{m}^{3}\right)\end{array}$ & $\begin{array}{c}\text { Total Dssi } \\
\text { Conc. } \\
\left(\mathrm{mg}^{3}\right)\end{array}$ \\
\hline & & & & & \\
AC-1 & & & & & \\
PV 3 & $03 / 22 / 88$ & 118 & 992 & 2.3739 & 0.0497 \\
PV 5 & $03 / 24 / 88$ & 389 & 65 & 0.1249 & 3.1145 \\
PV 6 & $03 / 30 / 88$ & 692 & 338 & 0.6365 & 1.0872 \\
PV 9 & $03 / 30 / 88$ & 1652 & 900 & 1.7253 & 0.9575 \\
PV 15 & $03 / 30 / 88$ & 128 & 206 & 0.4668 & 0.2742 \\
& & & & & \\
AC-2 & & & & & \\
PV 17 & $04 / 13 / 88$ & 66 & 720 & 1.237 & 0.0534 \\
PV 22 & $04 / 20 / 88$ & 58 & 211 & 0.3622 & 0.1601 \\
PV 31 & $04 / 14 / 88$ & 340 & 372 & 0.7053 & 0.4821 \\
PV 36 & $04 / 20 / 88$ & 121 & 218 & 0.4694 & 0.2578 \\
PV 47 & $04 / 14 / 88$ & 342 & 368 & 0.6837 & 0.5002 \\
PV i3B & $04 / 07 / 88$ & -20 & 0 & 0 & 0 \\
\hline
\end{tabular}

then performed the silica analysis according to the National Institute of Occupational Safety and Health (NIOSH) $7500 \mathrm{x}$-ray powder diffraction method. ${ }^{18}$ [The NIOSH 7500 procedure wams of possible interference from feldspars or other aluminosilicates in the low limit of detection (LOD).]

4.3.3.1.3. Crrstalline Silica Amalysis. Table $V$ shows the sampling date, core hole, and collection location of each sample. The driller wore four cyclone samplers during AC-1 and wore three during $\mathrm{AC}-2$; helpers wore two samplers during $A C-1$ and only one during AC-2. A helper performed the DCT cleaning or was in the collar/DCT area when leaks occurred; frequently, the drilling consultant was also in this area.

The x-ray diffraction analysis detected quartz, cristobalite, and tridymite. Table VI provides the results of the silica analysis. (See Appendix D-2 for complete data.) FW-625 contained measurable quartz, quantified at $0.04 \mathrm{mg}$. This area sampler was positioned such that it captured fugitive dust during collar leaks. Quartz was reported as
"(0.02 mg)" for 4 samples and 1 blank. This value was within the $L O D=0.015 \mathrm{mg}$ and the lower limit of quantification (LOQ $=0.03 \mathrm{mg}$ ) for the DataChem instrumentation. Calculations of the quartz 8-hour TWAs for these samples collected during the short-term drilling operations showed that values were lower than the ACGIH TLVITWA for respirable silica.

Table VI also lists the total respirable dust collected. The range for AC-1 was $0.32-2.74 \mathrm{mg} / \mathrm{m}^{3}$. with an average $=1.02 \mathrm{mg}^{3}$, and $0.17-0.43$ $\mathrm{mg} / \mathrm{m}^{3}$, with an average $=0.27 \mathrm{mg} / \mathrm{m}^{3}$ for $\mathrm{AC}-2$. Again the dust reduction was seen for AC-2 when compared with AC-1.

These values are consistent with those reported (less than $15.5 \mathrm{lg}$ or below the LOD) by REECo Industrial Hygiene for REECo silica samples collected during AC-1. The only REECo respirable dust sample was collected on the driller, with a concentration of $0.86 \mathrm{mg}^{3} \mathrm{~m}^{3} .19$

DataChem's technical manager ordered and personally checked a rerun analysis on blind blank FW $400-B$ and affirmed the presence of the appro- 
TABLE V

SILICA SAMPLING LOCATIONS

\begin{tabular}{|c|c|c|}
\hline $\begin{array}{l}\text { Sample } \\
\text { Date }\end{array}$ & $\begin{array}{l}\text { Sample } \\
\text { ID }\end{array}$ & Sampling Location \\
\hline \multicolumn{3}{|l|}{ AC-1 } \\
\hline $03 / 22 / 88$ & FW 610 & BACKGROUND-Demonstration Drift, on DCT $-4 \mathrm{ft}$ floor \\
\hline $03 / 22 / 88$ & FW 611 & BACKGROUND-Right side, approx. $8 \mathrm{ft}$ face, -4 fi floor \\
\hline $03 / 23 / 88$ & FW 612 & PS $^{\text {a }- \text { helper, DCT \& collar leak }}$ \\
\hline $03 / 23 / 88$ & FW 616 & PS-driller \\
\hline 03/24/88 & FW 619-B & BLIND BLANK - FW samples \\
\hline 03/25/88 & FW 614 & PS-driller \\
\hline $03 / 25 / 88$ & FW 613 & PS-drilling consultant \\
\hline 03/29/88 & FW 615 & PS-driller \\
\hline 03/29/88 & FW 624 & PS-helper (no weight gain) \\
\hline 03/29/88 & FW 625 & Demonstration Drift face between DCT \& collar \\
\hline $03 / 29 / 88$ & FW 622 & PS-drilling consultant \\
\hline $03 / 29 / 88$ & FW 621 & PS-investigator \\
\hline $03 / 30 / 88$ & FW 627 & Demonstration Drift, right wall above impactor \\
\hline $03 / 30 / 88$ & FW 620 & PS-drilkr \\
\hline 03/30/88 & FW 626 & Demonstration Drift, left wall above impactor \\
\hline 03/30/88 & FW 623 & PS-drilling consultant \\
\hline $04 / 05 / 88$ & FW 407-B & BLIND BLANK - FW samples \\
\hline \multicolumn{3}{|l|}{ AC-2 } \\
\hline $04 / 13 / 88$ & FW 630 & BACKGROUND-Laser-On drill hoist chain \\
\hline $04 / 14 / 88$ & FW 632 & PS-driller \\
\hline $04 / 14 / 88$ & FW 633 & $\begin{array}{l}15 \text { ft Dr wall, centered between DCT \& wall, } \\
\text { approximately } 4 \text { ft floor }\end{array}$ \\
\hline $04 / 14 / 88$ & FW 631 & Laser Drift, Right wall in line w/DCT \\
\hline 04/19/88 & FW 391 & PS-driller \\
\hline 04/19/88 & FW 394 & Wire hanger $6 \mathrm{ft}$ high in personnel area \\
\hline 04/19/88 & FW 634-B & BLIND BLANK - FW samples \\
\hline $04 / 20 / 88$ & FW 392 & PS-(wearer Out of Area approx. $25 \mathrm{~m} \mathrm{AM}+$ approx. $45 \mathrm{~m}$ PM) \\
\hline 04/20/88 & FW 393 & Laser, rock bolt 6 -ft from drill collar \\
\hline $04 / 20 / 88$ & FW 396 & Laser Incline just below core boxes \\
\hline $04 / 20 / 88$ & FW 398 & PS-driller \\
\hline $04 / 20 / 88$ & FW 399 & Wire hanger $6 \mathrm{ft}$ high in personnel area \\
\hline 04/20/88 & FW 641 & PS-driller \\
\hline 04/20/88 & FW 395 & Laser Drif, on front of DCT \\
\hline $04 / 21 / 88$ & FW 400-B & BLIND BLANK - FW samples \\
\hline
\end{tabular}

a.personal sample. 
TABLE VI

CRYSTALLINE SILICA REPORT

NOTE: Cristobalite or Tridymite was not detected in any sample.

\begin{tabular}{|c|c|c|c|c|c|c|c|}
\hline \multirow[b]{2}{*}{ Sample } & \multirow{2}{*}{$\begin{array}{l}\text { Total } \\
\text { Mass } \\
(\mathrm{mg})\end{array}$} & \multirow{2}{*}{$\begin{array}{c}\text { Air } \\
\text { Volume } \\
\left(\mathrm{m}^{3}\right)\end{array}$} & \multirow{2}{*}{\multicolumn{2}{|c|}{$\begin{array}{c}\text { Respirable } \\
\text { Dusi } \\
\text { (mo) } \\
\left(m^{3}\right)\end{array}$}} & \multicolumn{3}{|c|}{ Ouartz } \\
\hline & & & & & $\begin{array}{l}\text { Mass } \\
\text { (mg) }\end{array}$ & $\begin{array}{l}\text { Conc. } \\
\mathrm{mg} / \mathrm{m}^{3}\end{array}$ & $\begin{array}{l}\text { 8-Hour } \\
\text { TWA }\end{array}$ \\
\hline
\end{tabular}

AC-1

AW 610

FW 611

FW 612

FW 616

FW 619-B

0.03

0.168

0.18

0.03

0.172

0.20

0.127

FW 614

0.12

0.257

FW 613

$-0.02$

0.121

FW 615

0.18

0.106

FW 624

0.29

0.357

FW 625

0.18

0.224

FW 622

$-0.01$

0.205

FW 621

0.52

0.216

FW 627

0.14

0.198

FW 620

0.11

0.568

FW 626

0.11

0.275

FW 623

0.14

0.574

FW 407-B

0.38

0.402

0.13

0.088

102

1.16

0.94

0

73

1.49

65

2.74

0.5

0

125

2.54

0.65

0.54

0.19

0.51

0.66

0.32

0

NDa

ND

$(0.02)^{b}$

(0.12)

(0.03)

ND

ND

$(0.02)^{\mathrm{b}}$

$(0.02)^{b}$

(0.17)

(0.19)

ND

ND

$0.04^{c}$

ND

ND

ND

ND

ND

ND

ND

AC-2

FW 630

FW 632

FW 633

FW 631

FW 391

FW 394

FW 634-B

FW 392

FW 393

FW 396

FW 398

FW 399

FW 641

FW 395

FW 400-B

0.03

1.23

0.366

0.15

0.427

0.10

0.588

0.13

0.454

0.12

0.459

0.15

0.324

0

0.435

0.10

0.426

0.10

0.318

0.04

0.312

0.10

0.253

0.11

0.630

0.11

0.426

0.13

0.420

0.02

0.41

0.23

0.22

0.26

0.33

0

257

0.03
0.23

0.23

0.13

0.32

0.43

0.17

0.31

0

0
ND

ND

ND

ND

ND

ND

ND

$(0.02)^{b} \quad(0.05)$

ND

ND

ND

ND

ND

ND

$(0.02)^{b, d}$ $\mathrm{a}_{\text {Not detected (ND) }}$

$b_{L O D}=0.015 \mathrm{mg}$

$c_{\mathrm{LOQ}}=0.03 \mathrm{mg}$

dSample rechecked by DataChem
ACGIH TLV/TWA

Total Respirable Dust $=10 \mathrm{mg} / \mathrm{m}^{3}$

Quartz (respirable) $=0.1 \mathrm{mg} / \mathrm{m}^{3}$ 
priate peaks indicating quartz. Regarding the indicated weight gain for blind blank FW 407-B, the manager checked the DataChem notebook and with the analyst regarding the duplicate weighings of both the prepared membrane and the submitted sample. He suggested that possibly a contaminant (dust speck or filter cutting) was picked up inadvertently during pre-weighing of the membrane and then knocked off during loading into the cassette.

After careful consideration, it was determined that these blank analyses would not jeopardize any interpretation of the results.

Bulk samples were selected from the DCT collection bag for AC-1 Run $\$ 7$ in Demonstration Drift and AC-2 Runs \#8 through \#12 in Laser Drift. Splits of these were sent to DataChem for analysis. Table VII provides the quartz bulk analysis. Again no cristobalite or tridymite was detected. There was $6.8 \%$ quartz delected in the AC-1 dust and $11.0 \%$ detected in the AC- 2 dust.

4.3.3.2. Mixed Cellulose Ester Fiber (MCEF) Membranes. MCEF membranes (0.8- $\mu \mathrm{m}$ pore size, 25-mm gridded) loaded into three-piece, 2-in., electrically conductive, 25-mm carton-filled polypropylene air monitor cassettes were used for fiber counting. Table VIII provides the sampiing information for the fiber samples. Complete data on each sample are in Appendix D-3.
4.3.3.2.1. Phase Contrast Microscopy. The objective of this procedure was to pmvide information about concentrations of aibome mineral fibers produced during dry drilling operations at the YMP worksite. Samples were field coilected on membrane-filter (cellulose ester) substrates for various intervals during dry drilling workdays. Particulate-loaded filters were evaluated for fiber content by use of a microscopic fiber counting method derived from the existing airbome asbestos monitoring standard (NIOSH Method 7400). ${ }^{20}$ This method employs phase contrast microscopy and relies on the microscopist to distinguish fibers from nonfibers. [Fibers are defined as any particle having an aspect ratio (length versus width) $\geq 3: 1$.] Fibers were counted by phase contrast microscopy. with well-defined rules at a fixed magnification of $400 \mathrm{x}$, and the accumulated fiber counts were then translated to airbome fiber concentration levels for subsequent risk assessment evaluation.

Thirty-seven individual membrane filters (including six blank filters) were examined microscopically for fiber content. Few fibers were detected on any of these samples. Fiber count results obtained from these samples fell into two general categories: (1) filters containing primarily nonfibrous particulates with very few fibers discemible at $400 \mathrm{x}$ (i.e., fiber counts consistent with

TABLE VII

BIJKK SILICA SAMPLES

\begin{tabular}{lcccc}
$\begin{array}{l}\text { Sample } \\
\text { No. }\end{array}$ & $\begin{array}{c}\text { Sample } \\
\text { Date }\end{array}$ & $\begin{array}{c}\text { Quartz } \\
(\%)\end{array}$ & $\begin{array}{c}\text { Cristobalite } \\
(\%)\end{array}$ & $\begin{array}{r}\text { Tridym } \\
(\%)\end{array}$ \\
\hline & & & & ND \\
AC-1-R7 \#3 & $03 / 29 / 88$ & 6.8 & ND & ND \\
AC-2-R8-12 \#3 & $04 / 13 / 88$ & 11.0 & &
\end{tabular}

$\mathrm{ND}=$ Not detected

LOD $=0.75 \%$

$\mathrm{LOQ}=1.5 \%$ 
TABLE VIII

FIBER SAMPLING LOCATIONS

\begin{tabular}{cc}
\hline Sample & Sample \\
No. & Date
\end{tabular}

Sampling Location

AC-1

CE 52

$03 / 22 / 88$

CE 53

$03 / 23 / 88$

CE 54

$03 / 23 / 88$

CE 55

$03 / 23 / 88$

CE 75B

$03 / 24 / 88$

CE 50B

$03 / 28 / 88$

CE 56

$03 / 25 / 88$

CE 57

$03 / 25 / 88$

CE 45B

$04 / 04 / 88$

CE 49B

04/04/88

CE 58

$03 / 31 / 88$

CE 59

$03 / 30 / 88$

CE 60

$03 / 30 / 88$

CE 61

$03 / 30 / 88$

CE 62

$03 / 30 / 88$

CE $64 \quad 03 / 30 / 88$

CE $65 \quad 03 / 30 / 88$

CE $66 \quad 03 / 30 / 88$

CE $67 \quad 03 / 30 / 88$

CE $68 \quad 03 / 31 / 88$

CE $69 \quad 03 / 30 / 88$

CE $74 \quad 03 / 30 / 88$

AC-2

CE 71

$04 / 13 / 88$

CE 72

$04 / 14 / 88$

CE 73B

$04 / 15 / 88$

CE 1

$04 / 14 / 89$

CE 2

$04 / 14 / 88$

CE 4

$04 / 14 / 88$

CE 6

$04 / 14 / 88$

CE $3 \quad 04 / 20 / 88$

CE $7 \quad 04 / 20 / 88$

CE $8 \quad 04 / 20 / 88$

CE $12 \quad 04 / 20 / 88$

CE $13 \quad 04 / 20 / 88$

CE $17 \quad 04 / 20 / 88$

CE $19 \quad 04 / 20 / 88$

CE 20B $\quad 04 / 26 / 88$

BACKGROUND sample, positioned on drill

Right wall, $-3 \mathrm{ft}$ behind impactor, $-6 \mathrm{ft}$ above floor

Left wall, approximately $6.5 \mathrm{ft}$ above face

Hanging above drill rig

BLIND BLANK - CE samples

BLIND BLANK - CE samples

PERSONAL SAMPLE

PERSONAL SAMPLE

BLIND BLANK - CE samples

BLIND BLANK - CE samples

At drill to left of operator

Left wall, even with drill

Behind drill, to the left

Right wall near DCT

Between wall and drill

On face in Demonstration Drift

Between wall and drill rig

Right wall near DCT

At face in Demonstration Drift

Left wall just behind drill plane

Right wall near impactor at CE sample site

At drill rig between drill and wall

BACKGROUND, on Rock bolt left of drill collar On wall approximately $5 \mathrm{ft}$ to right of drill collar

BLIND BLANK - CE samples

Hanger between drill and table (personal area)

On wall between DCT and drill collar

On wall, approximately $5 \mathrm{ft}$ right of drill collar

On wall between DCT and drill coilar

On water box in middle of drift

On DCT

On DCT

On wall by impactor, between drill and cable

On DCT

On water box in middle of drift

On wall behind DCT

BLIND BLANK - CE samples 
blank/background levels), and (2) filters that were uncountable because of high particulate loading (high loading levels of deposited particulates obscure and mask possible collected fibers, making fiber detection/counting impossible). Fiber counts were obtained (from countable filters) by counting the minimum 100 optical fields. Individual fiber count results from this 37-sample field test series are listed in Taole IX.

The general observation/conclusion of these fiber assessment analyses is that very few fibers were in the airborne dust samples collected. The primary particulate material on all filter samples was nonfibrous.

Only two membranes (CE 6 and CE 72), of all filters examined, contained obvious, well-defined fibrous particulates. These fibrous particles were few, unusual because of their presence in only 2 of 35 samples, and conspicuously different in morphology from anticipated erionite/mordenite previously observed in reference materials. Both samples (CE 6 and $C E$ 72) were collected at the same general locale (near the drilling face) during the same drilling interval on the same sampling day.
Filters CE 6 and CE 72 contained fiber concentrations of 16.5 and 34.0 fibers $/ \mathrm{mm}^{2}$, respectively. These filter deposit concentrations translate to airbome concentration of $<0.05$ fibers $/ \mathrm{cm}^{3}$ for $C E 6$ and 0.2 fibers $/ \mathrm{cm}^{3}$ for $\mathrm{CE} 72$, when respective sampled air volumes are included. Thus, sample CE 72 is the only sample of this 35-sample field test series that contained an airbome fiber concentration level approaching the current permissible exposure limit (PEL) established for asbestos (currently 0.2 fibers $/ \mathrm{cm}^{3}$ ). It is important, however, to emphasize that the PCM, SEM/EDX evaluation sample CE 72, indicates that the sample did not contain asbestos, erionite, or mordenite. The collected fibers in samples CE 6 and CE 72 have been identified as crystalline $\mathrm{CaSO}_{4}$, typically regarded as a nuisance dust for which the ACGIH TLV/TWA is $10 \mathrm{mg} / \mathrm{m}^{3}$. These crystals have optical properties, morphology, and elemental composition consistent with the fibrous crystals in the mortar (Sulfaset from Randustral Co., Cleveland, Ohio) used at the YMP test drilling site. Sulfaset is a plaster-of-paris $\left(\mathrm{CaSO}_{4}\right)$-based packing mud used for sealing the drill collar to the drilling (rock) face.

TABLE IX

YUCCA MOUNTAIN PROJECT AIR CORING FIELD TEST FIBER COUNT AND AIRBORNE CONCENTRATION DATA ${ }^{a}$

\begin{tabular}{|c|c|c|c|c|}
\hline $\begin{array}{c}\text { Sample } \\
\text { No. }\end{array}$ & $\begin{array}{l}\text { Fibers Counted } \\
\text { per } 100 \\
\text { Optical Fields }\end{array}$ & $\begin{array}{l}\text { Sampling } \\
\text { Volume } \\
\text { (L) }\end{array}$ & $\begin{array}{l}\text { Airborne } \\
\text { Fiber Conc. } \\
\left(\mathrm{f} / \mathrm{cm}^{3}\right)\end{array}$ & Comments \\
\hline CE 52 & 2 & 1278.0 & - & Uncountable $^{\mathbf{b}}$ \\
\hline CE 53 & - & 129.1 & - & Uncountable $^{b}$ \\
\hline CE 54 & - & 122.7 & - & Uncountable ${ }^{b}$ \\
\hline CE 55 & - & 106.3 & - & Uncountable $^{b}$ \\
\hline CE 75 & 0 & - & - & Filter Blank \\
\hline CE 50 & 2 & - & - & Filter Blank \\
\hline CE 56 & - & 121.7 & - & Uncountable $^{\mathrm{b}}$ \\
\hline CE 57 & 4 & 147.4 & $<0.05$ & Deposit Nonfibrous \\
\hline CE 45 & 1 & - & - & Filter Blank \\
\hline CE 49 & 2 & - & - & Filter Blank \\
\hline CE 58 & 2 & 29.9 & $<0.05$ & Deposit Nonfibrous \\
\hline CE 59 & 3 & 109.7 & $<0.05$ & Deposit Nonfibrous \\
\hline CE 60 & 1 & 55.0 & $<0.05$ & Deposit Nonfibrous \\
\hline
\end{tabular}




\begin{tabular}{|c|c|c|c|c|}
\hline CE 61 & - & 27.1 & - & $\begin{array}{l}\text { Very Few Particles } \\
\text { Back-up Separator } \\
\text { Paper In Place }\end{array}$ \\
\hline CE 62 & 7 & 57.3 & 0.06 & $\begin{array}{l}\text { Few Fibers-Deposit } \\
\text { Nonfibrous }\end{array}$ \\
\hline CE 64 & 6 & 62.3 & 0.05 & $\begin{array}{l}\text { Few Fibers-Deposil } \\
\text { Nonfibrous }\end{array}$ \\
\hline CE 65 & 4 & 43.9 & $<0.05$ & $\begin{array}{l}\text { Few Fibers-Deposit } \\
\text { Nonfibrous }\end{array}$ \\
\hline CE 66 & 4 & 54.2 & $<0.05$ & $\begin{array}{l}\text { Few Fibers-Deposit } \\
\text { Nonfibrous }\end{array}$ \\
\hline CE 67 & 4 & 31.1 & 0.06 & $\begin{array}{l}\text { Few Fibers-Deposit } \\
\text { Nonfibrous }\end{array}$ \\
\hline CE 68 & 4 & 31.1 & 0.06 & $\begin{array}{l}\text { Few Fibers-Deposit } \\
\text { Nonfibrous }\end{array}$ \\
\hline CE 69 & 3 & 30.2 & 0.05 & Vehicle Exhaust \\
\hline CE 74 & 3 & 86.0 & $<0.05$ & Vehicle Exhaust \\
\hline CE 1 & 2 & 127.8 & $<0.05$ & Deposit Nonfibrous \\
\hline CE 2 & 3 & 127.5 & $<0.05$ & Deposit Nonfibrous \\
\hline CE 4 & 2 & 37.0 & $<0.05$ & Deposit Nonfibrous \\
\hline CE 6 & 13 & - & $<0.05$ & $\begin{array}{l}\text { Some Fibers-Deposit } \\
\text { Light }\end{array}$ \\
\hline CE 71 & 1 & 1436.4 & $<0.05$ & Deposit Nonfibrous \\
\hline CE 72 & 27 & 58.5 & 0.22 & $\begin{array}{l}\text { Some Fibers-Unusual } \\
\text { Morphology }\end{array}$ \\
\hline CE 73 & 2 & - & - & Filter Blank \\
\hline CE 3 & 3 & 121.4 & $<0.05$ & Vehicle Exhaust \\
\hline CE 7 & 2 & 185.5 & $<0.05$ & Deposit Nonfibrous \\
\hline CE 8 & 1 & 61.8 & $<0.05$ & Deposit Nonfibrous \\
\hline CE12 & 2 & 290.8 & $<0.05$ & Deposit Nonfibrous \\
\hline CE 13 & 2 & 123.7 & $<0.05$ & $\begin{array}{l}\text { Deposit Nonfibrous } \\
\text { and Vehicle Exhaust }\end{array}$ \\
\hline CE 17 & 2 & 121.4 & $<0.05$ & Vehicle Exhaust \\
\hline CE 19 & 1 & 60.7 & $<0.05$ & Deposit Very Light \\
\hline CE 20 & 1 & - & - & Filter Blank \\
\hline
\end{tabular}

Total Filters $=37$ (including 6 blanks)

aFiber counts obtained by phase contrast microscopy at 400x magnification.

Fibers were uncountable because of high pariculate loading. 
It is likely that the fibrous $\mathrm{CaSO}_{4}$ crystals collected on samples CE 6 and CE 72 originated from this packing mud (Fig. 10).

The collection and detection of these fibrous $\mathrm{CaSO}_{4}$ crystals demonstrate that the monitoring/analytical techniques used can detect fibrousshaped particulates at very low airbome concentrations $\left(<0.05\right.$ fibers $\left./ \mathrm{cm}^{3}\right)$. The geologists have confirmed our finding by stating that fibrous zeolites have not been identified in these areas.

4.3.3.3. Nuclepore Polycarbonate Mem: branes. The membranes $(0.2-\mu \mathrm{m}$ pore size, $25-\mathrm{mm}$ diam) loaded into $25-\mathrm{mm}, 2$-in. styrene acrylonitrile, air monitor cassettes were used as samples to be analyzed by (a) photon-induced $x$-ray emission (PIXE) analysis and (b) SEM with EDX. (a) Photon-Induced X-Ray Emission Analysis was performed by Elemental Analysis Corporation (EAC), Tallahassee, Florida. PIXE analysis provides nondestructive detection and quantification for the elements sodium through uranium. Ten filter samples and two blind blanks were analyzed. The elemental determination for each sample is presented in Appendix D-4. Table X contains the date collected, core hole, and location of the sampler in the drift.

According to the Fenix \& Scisson G-Tunnel geologist, both core holes were dritled in the welded Grouse Canyon Member tuff, Unit B, with $A C-1$ in the lower section and AC-2 in the upper section. When the PIXE analyses of the samples are companed with the whole-rock chemical analyses found in Connolly and Keil ${ }^{21}$ (Table XI),

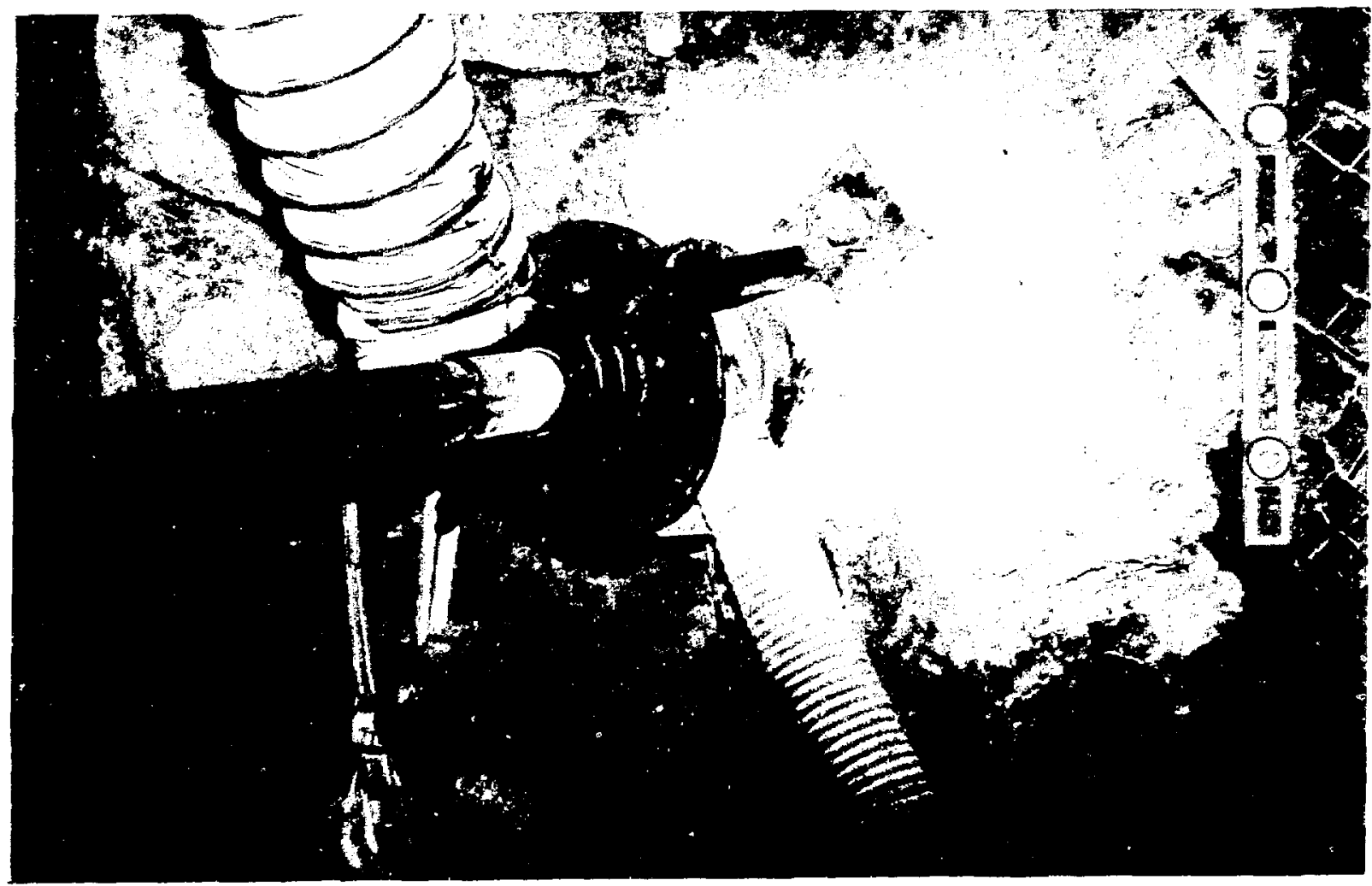

Figure 10. Sulfaset (light area) anchoring spidericollar to wall in Laser Drift. 
TABLE X

\section{PIXE SAMPLING LOCATIOIJS}

\begin{tabular}{|c|c|c|}
\hline $\begin{array}{l}\text { Sample } \\
\text { Date }\end{array}$ & $\begin{array}{l}\text { Sample } \\
\text { No. }\end{array}$ & Sampling Location \\
\hline \multicolumn{3}{|l|}{ AC-1 } \\
\hline 03/29/88 & NP 52 & $\begin{array}{l}\text { PERSONAL SAMPLE on } \\
\text { investigator }\end{array}$ \\
\hline $03 / 30 / 88$ & NP 59 & $\begin{array}{l}\text { Left wall (approx. } 8 \mathrm{ft} \text { from } \\
\text { face) even with drill }\end{array}$ \\
\hline $03 / 30 / 88$ & NP 55 & $\begin{array}{l}\text { On wall of Extensiometer/ } \\
\text { Demonstration curve }\end{array}$ \\
\hline \multicolumn{3}{|l|}{$A C-2$} \\
\hline $04 / 12 / 88$ & NP 47B & $\begin{array}{l}\text { BLIND BLANK - PIXE sample } \\
\text { set }\end{array}$ \\
\hline 04/19/88 & NP 56 & $\begin{array}{l}\text { On face }-6.5 \mathrm{ft} \text { Right of collar, } \\
\sim 7 \mathrm{ft} \text { from DCT }\end{array}$ \\
\hline $04 / 19 / 88$ & NP 5 & On DCT front \\
\hline $04 / 20 / 88$ & NP 22 & $\begin{array}{l}\text { On wire (middle of personnel } \\
\text { area) }\end{array}$ \\
\hline 04/20/88 & NP 4 & On DCT \\
\hline $04 / 21 / 88$ & NP 27 & $\begin{array}{l}\text { On wall between DCT and drill } \\
\text { collar }\end{array}$ \\
\hline $04 / 21 / 88$ & NP 10 & $\begin{array}{l}\text { On face, between collar } \\
\text { (approx. } 5 \mathrm{ft} \text { ) and DCT }\end{array}$ \\
\hline $04 / 21 / 88$ & NP 14 & On DCT front \\
\hline $04 / 28 / 88$ & NP 32B & $\begin{array}{l}\text { BLIND BLANK - PIXE sample } \\
\text { set }\end{array}$ \\
\hline
\end{tabular}

we see the similar distribution of elements. PIXE, however, reports individual elements, not oxides.

Samples NP 52 from AC-1 and NP 14 from AC. 2 were chosen for trace element comparisons with the ACGIH threshold limit values. Table XII lists these data. The quantities reported for these representative samples would not cause a hazard to area personnel.

After the PIXE data were reviewed, it also became evident that each Nuclepore polycarbonate membrane filter contained bromine. We subsequently learned that the manufacturer uses bromine as a hurdener in the production of the membranes and does not mention that in the literature. Fortunately, quantification of tracers such as lithium bromide was not part of the study.
PIXE analyses were performed on splits of the bulk samples AC-1 Run $\# 7$ and AC-2 Runs $\# 8-12$ and found to contain approximately the same elemental distribution as the membrane-filter samples.

43.3.4. Sconning Electron Microscopy (SEM) and Energy Disnersive X-ray (EDX) Anlysis. Table XIII gives the collection dates, the core bole, and the sampling locations for the samples examined by SEM/EDX. Complete data for each sample are found in Appendix D-5.

Fifty membrane-filter air samples (including seven blank samples) were examined in the scanning electron microscope, with no fibers detected. All particles observed on the collection membranes were either nonfibrous or loosely bound agglomerates of nonfibmous particles. The majority of all filters contained very few particles. (A fiber is defined as any elongated particle having a minimum 3:1 aspect ratio.)

The membrane filters were prepared and analyzed according to detailed procedures. Each filter section had 100-300 fields screened, looking specifically for fibers, at $5000 \mathrm{x}$ magnification. Fifty to one hundred of these fields were examined in detail at $10000 \times$ magnification.

The first six filters from the field task series were prepared with a carbon-coating technique for subsequent EDX analysis. Each of these filters had photomicrographs (3) and EDX spectra obtained from them. Examples of these data are shown in Figs. 11 and 12.

Because resolution was poor with carbon coating on such fine particulates, the remaining filters were gold sputter coated, making it much casier and faster to search/screen for fibers on the collection filter surface. Only one photomicrograph was taken from each of these filters for documentation/reconding (Fig. 13).

The significant observation of these SEM/EDX particle examination experiments was that no fibrous particles were detected on sny of these membrane-filter-collected samples.

One bulk sample was selected from each of the DCT cuttings/collection bag for AC-1 Run $; 7$ and AC-2 Runs \#8-12. Splits of these samples were submitted for SEM/EDX analysis. The samples were prepared, gold-coated, and analyzed according to detailed procedures. No fibrous particles were detected for these two samples. 
TABLEXI

WHOLE-ROCK CHEMICAL, ANALYSES OFTUFP SAMPLES FROM G.TUNNEL 20

\begin{tabular}{|c|c|c|c|c|c|c|c|c|c|c|c|c|c|}
\hline \multicolumn{14}{|l|}{ Anelyst: } \\
\hline \multicolumn{14}{|l|}{ Unit } \\
\hline Designetion & TES & $\mathbf{A}$ & $\mathbf{A}$ & A & $\boldsymbol{\lambda}$ & B & $\mathbf{B}$ & B & B & C & C & c & UTZ \\
\hline \multirow[t]{2}{*}{ sample } & HB-MPBX & AMD-2 & 61045 & G10:5 & G10:1 & RWD-4 & $R+D-6$ & RHD-9 & G10:1 & R:D-10 & ED-2 & G10:1 & ED-5 \\
\hline & 20.7 & & 1353.8 & 1361.3 & 1368.2 & & & & 1343.4 & & & 1343.4 & \\
\hline \multicolumn{14}{|l|}{ Qxidents: } \\
\hline $\mathrm{S1O}_{2}$ & 67.46 & 64.26 & 68.46 & 73.43 & 80.14 & 74.73 & 71.33 & 72.83 & 72.25 & 73.63 & 73.83 & 71.01 & 63.48 \\
\hline $\mathrm{THO}_{2}$ & 0.20 & 0.18 & 0.25 & 0.25 & 0.15 & 0.19 & 0.26 & 0.24 & 0.34 & 0.28 & 0.30 & 0.33 & 0.39 \\
\hline $\mathrm{Al}_{2} \mathrm{O}_{3}$ & 11.88 & 11.66 & 14.80 & 12.98 & 8.60 & 11.25 & 13.00 & 11.80 & 13.20 & 12.16 & 12.54 & 13.50 & 14.30 \\
\hline $\mathrm{E}_{2} \mathrm{O}_{3}$ & 2.73 & 3.38 & 3.90 & 2.77 & 2.00 & 2.50 & 2.46 & 2.24 & 3.07 & 2.65 & 3.09 & 2.92 & 2.99 \\
\hline$E=0$ & $0.01^{2}$ & 0.40 & 0.11 & 0.75 & 0.12 & 1.13 & 1.60 & 2.51 & 0.23 & 0.73 & 0.19 & 0.31 & 0.04 \\
\hline MnO & 0.121 & 0.156 & 0.170 & 0.152 & 0.094 & 0.132 & 0.154 & 0.148 & 0.147 & 0.145 & 0.147 & 0.162 & 0.153 \\
\hline $\mathrm{MgO}$ & 0.205 & 0.26 & 0.084 & 0.084 & 0.042 & 0.06 & 0.06 & 0.10 & 0.10 & 0.05 & 0.112 & 0.11 & 0.56 \\
\hline $\mathrm{CaO}$ & 1.66 & 2.07 & 0.14 & 0.14 & 0.13 & 0.19 & 0.33 & 0.36 & 0.24 & 0.18 & 0.19 & 0.16 & 1.85 \\
\hline $\mathrm{H}_{2}{ }_{2} \mathrm{O}$ & 1.52 & 2.33 & 2.54 & 3.05 & 2.12 & 3.40 & 4.25 & 3.95 & 4.53 & 3.47 & 2.70 & 4.06 & 1.29 \\
\hline$x_{2} 0$ & 3.12 & 3.24 & 0.12 & 5.12 & 4.85 & 5.30 & 5.53 & 4.84 & 5.19 & 5.40 & 5.70 & 6.33 & 5.38 \\
\hline $\mathrm{H}_{2} \mathrm{OH}$ & 6.08 & 6.81 & 0.66 & 0.52 & 1.05 & 0.54 & 0.34 & 0.34 & 0.63 & 0.79 & 0.48 & 0.83 & 5.61 \\
\hline $\mathrm{H}_{2} \mathrm{O}-$ & 4.60 & 5.22 & 0.28 & 0.21 & 0.19 & 0.08 & 0.08 & 0.14 & 0.16 & 0.13 & 0.21 & 0.185 & 3.53 \\
\hline $\mathrm{P}_{2} \mathrm{O}_{5}$ & 0.019 & 0.01 & 0.019 & 0.020 & 0.010 & 0.02 & 0.12 & 0.04 & 0.027 & 0.031 & 0.034 & 0.041 & 0.039 \\
\hline sro & 0.002 & 0.003 & 0.001 & $0.001^{2}$ & 0.001 & $0.001^{a}$ & $0.001^{a}$ & 0.001 & $0.002^{2}$ & $0.002^{2}$ & $0.001^{\star}$ & $0.001^{\star}$ & 0.007 \\
\hline - 5 & 0.01 & $0.01^{2}$ & 0.01 & $0.01 \AA$ & 0.01 & $0.02^{\star}$ & $0.01^{2}$ & 0.01 & 0.01 & 0.01 & $0.01^{2}$ & $0.01^{a}$ & $0.01 \%$ \\
\hline Total & 99.60 & 99.98 & 99.53 & 99.48 & 99.30 & 99.52 & 99.51 & 99.54 & 200.1 & 99.65 & 99.52 & 99.95 & 99.54 \\
\hline $\mathrm{CaOb}$ & 33.9 & 33.9 & 1.9 & 2.4 & 2.6 & 3.0 & 4.4 & 5.3 & 3.2 & 2.8 & 3.2 & 2.1 & 30.1 \\
\hline $\mathrm{N} \otimes_{2} \mathrm{~b}$ & 28.1 & 34.5 & 31.6 & 16.4 & 30.0 & 47.9 & 51.5 & 52.4 & 55.2 & 48.0 & 40.5 & 48.3 & 17.8 \\
\hline $\mathrm{K}_{2} \mathrm{Ob}$ & 38.0 & 31.6 & 66.5 & 51.2 & 58.5 & 49.1 & $\$ 4.1$ & 42.3 & 11.6 & 49.2 & 56.3 & 49.6 & 52.1 \\
\hline Agpalt te Index & 0.495 & 0.629 & 0.876 & 0.013 & 1.02 & 1.01 & 0.990 & 0.994 & 0.990 & 0.949 & 0.846 & 1.00 & 0.546 \\
\hline $\begin{array}{l}\mathrm{Ma/E} \\
\text { (molocular) }\end{array}$ & 0.740 & 1.09 & 0.473 & 0.905 & 0.664 & 0.975 & 1.17 & 1.24 & 1.33 & 0.977 & 0.720 & 0.974 & 0.342 \\
\hline
\end{tabular}

Amount shown 1s below datoction 11 mit.

byolecular proportions, normalized to 1008 . 
TABLE XII

TRACE ELEMENT HAZARD ANALYSIS

\begin{tabular}{llll}
\hline Elements & $\begin{array}{c}\text { AC-1 } \\
\text { NP } 52\left(\mathrm{mg}^{3} \mathrm{~m}^{3}\right)\end{array}$ & $\begin{array}{c}\text { AC-2 } \\
\mathrm{NP} 14\left(\mathrm{mg}^{3} \mathrm{~m}^{3}\right)\end{array}$ & $\begin{array}{c}\text { ACGIH } \\
\text { TLV }\left(\mathrm{mg}^{21} \mathrm{~m}^{3}\right)\end{array}$ \\
\hline Aluminum & & & \\
Silicon & 0.0022 & 0.0031 & 10 \\
Phosphorus & 0.0072 & 0.0138 & $10^{\mathrm{a}}$ \\
Sulfur & 0 & 0.0002 & 0.1 \\
Chlorine & 0.0017 & 0.002 & 5 \\
Potassium & 0.0005 & 0.0006 & 1.5 \\
Calcium & 0.0009 & 0.0021 & 10 (as Potassium Silicate) \\
Titanium & 0.0012 & 0.0018 & 10 (as Calcium Silicate) \\
Chromium & 0.0003 & 0.0002 & $10^{\mathrm{a}}$ (as Titanium Dioxide) \\
Manganese & 0.003 & 0.0007 & 0.5 \\
Iron & 0 & 0.0013 & 5 \\
Nickel & 0.0015 & 0.0078 & 5 \\
Copper & $<0.05 \mu \mathrm{g} / \mathrm{m}^{3}$ & $<0.05 \mu \mathrm{g} / \mathrm{m}^{3}$ & 0.1 (if soluble) \\
Zinc & $<0.05 \mu \mathrm{g} / \mathrm{m}^{3}$ & $<0.05 \mu \mathrm{g} / \mathrm{m}^{3}$ & 1 \\
Bromine & $<0.05 \mu \mathrm{g} / \mathrm{m}^{3}$ & $<0.0002$ & 10 (as Zinc Oxide dust) \\
Strontium & 0.0001 & 0.0018 & 0.7 \\
Molybdenum & 0.0001 & 0 & 0 \\
Antimony & 0.0001 & 0 & 5 (if soluble) \\
Lead & 0.0001 & 0 & 0.5 \\
& 0.001 & $<0.05 \mu \mathrm{g} / \mathrm{m}^{3}$ & 0.15 (as dusts) \\
\hline
\end{tabular}

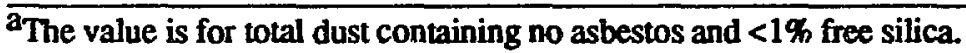


TABLE XIII

SEM/EDX SAMPLING LOCATIONS

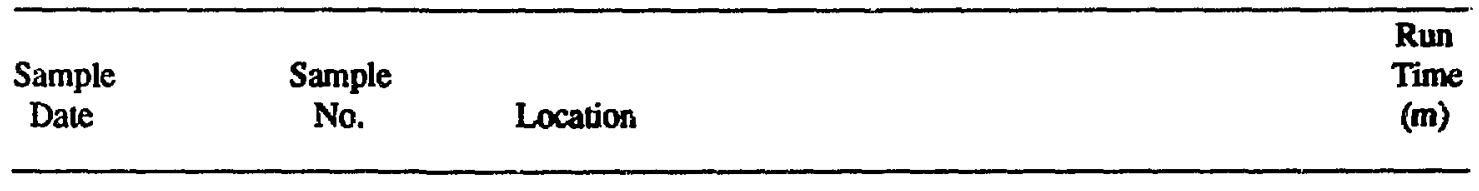

AC-1

03/22/88

$03 / 23 / 88$

$03 / 23 / 88$

$03 / 25 / 88$

$03 / 25 / 88$

$03 / 30 / 89$

$03 / 30 / 88$

03/30/88

03/30/88

$03 / 30 / 88$

$03 / 30 / 88$

03/30/88

$03 / 30 / 88$

$03 / 30 / 88$

$03 / 30 / 88$

$04 / 08 / 88$

$04 / 08 / 88$

AC-2

$04 / 12 / 88$

$04 / 13 / 88$

$04 / 14 / 88$

$04 / 14 / 88$

$04 / 14 / 88$

$04 / 18 / 88$

$04 / 18 / 88$

$04 / 19 / 88$

$04 / 19 / 88$

$04 / 19 / 88$

$04 / 19 / 88$

$04 / 19 / 88$

$04 / 19 / 88$

$04 / 19 / 88$

$04 / 19 / 88$

$04 / 19 / 88$

$04 / 19 / 88$

$04 / 19 / 88$

$04 / 19 / 88$
NP 71

NP 72

NP 73

NP 74

NP 75

NP 52

NP 59

NP 55

NP 51

NP 53

NP 54

NP 57

NP 63

NP 68

NP 69

NP 49B

NP $48 \dot{B}$

NP 47B

NP 50

NP 2

NP 1

NP 64

NP 67

NP 62

NP 56

NP 5

NP 66

NP 61

NP 35

NP 34

NP 24

NP 19

NP 17

NP 12

NP9

NP 6
BACKGROUND-Demonstration Drift

100

$A C I^{2}$ Location, left side of Demonstration Drift

Right wall Demonstration drift, near $\mathrm{ACI} \sim 6 \mathrm{ft}$

above floor

Personal sample on investigator

Personal sample on investigator

Personal sample on investigator

Left wall ( $\sim 8 \mathrm{ft}$ from face) even with drill

On wall of Extensiometer/Demonstration curve

On DCT

81

Right side Demonstration Drift even with drill

Personal sample on investigator

On DCT

On DCT

72

64.7

68.7

60

30

68.5

15

30

50

30

15

On wall of Extensiometer/Demonstration Curve $\quad 30$

On DCT (removed from set/contaninated) 0

BLINK BLANK - NP sample set

50

BLIND BLANK

BLANK-PIXE sample set

BACKGRCUND-on front of DCT 720

On DCT

362.9

On DCT

377

On water box between drill and table

70.7

On water box

30

On water box

30

On face $-6.5 \mathrm{ft}$ right of collar, $\rightarrow 7 \mathrm{ft}$ from $\mathrm{DCT}$

On DCT front $\quad 60$

On DCT

27

Between DCT and drill collar, $5 \mathrm{ft}$ right

of spider

120

Wall behind DCT

Wall behind DCT 45

Back wall between table and hanger $\quad 101$

On water box $\quad 30$

On water box

On water box, approximately $9.5 \mathrm{ft}$ from DCT

On front of DCT (small leak at DCT bag)

On water box, approximately $9.5 \mathrm{ft}$ from DCT 30 


\begin{tabular}{lllc}
$04 / 19 / 88$ & NP 7 & On water box, approxinately 9.5 ft from DCT & 60 \\
$04 / 20 / 88$ & NP 22 & On wire (middle of personnel area) & 209.5 \\
$04 / 20 / 88$ & NP 4 & On DCT & 152.9 \\
$04 / 20 / 88$ & NP 29 & At DCT & 102 \\
$04 / 20 / 88$ & NP 28 & On water box & 60 \\
$04 / 20 / 88$ & NP 26 & On water box & 60 \\
$04 / 20 / 88$ & NP 16 & Personal sample on investigator & 63 \\
$04 / 21 / 88$ & NP 27 & On wall between DCT and drill collar & 104 \\
$04 / 21 / 88$ & NP 10 & On face, between collar $(-5 \mathrm{ft}$ ) and DCT & $2^{\circ} 2$ \\
$04 / 21 / 88$ & NP 14 & On DCT front & 293.4 \\
$04 / 26 / 88$ & NP 40B & BLANK - NP sample set & 0 \\
$04 / 26 / 88$ & NP 33B & BLANK - NP sample set & 0 \\
$04 / 26 / 88$ & NP 58B & BLANK - NP sample set & 0 \\
$04 / 28 / 88$ & NP 32B & BLANK - PIXE sample set & 0 \\
\hline
\end{tabular}

andersen Cascasie Impactor. 

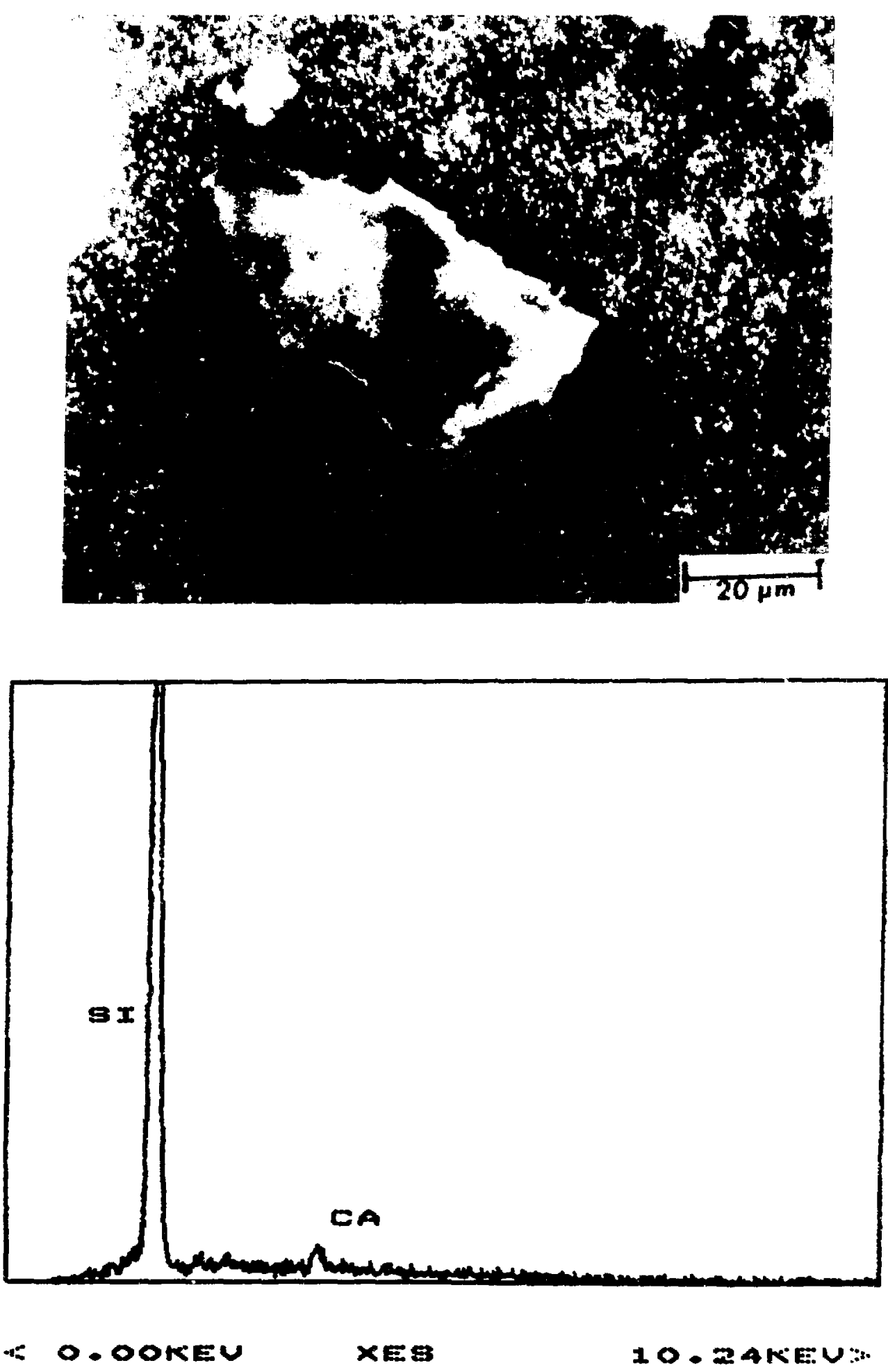

Figure 11. SEM Photomicrograph (1000x) and EDX Spectrim of NP0071-2. 

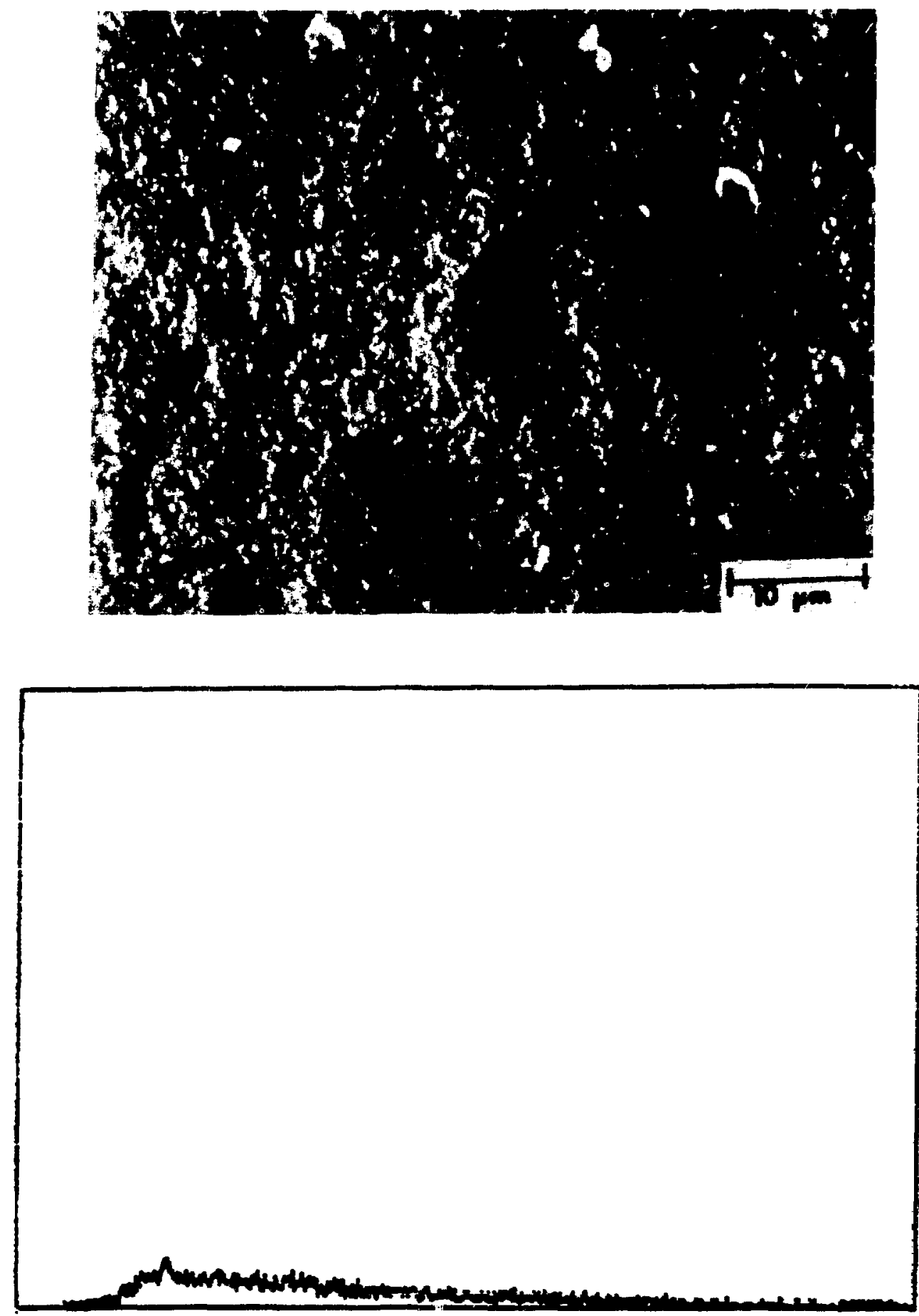

HO.OOKEU XEB

Figure 12. SEM Photomicrograph (2000x) and EDX Spectrum of NP0072-1. 


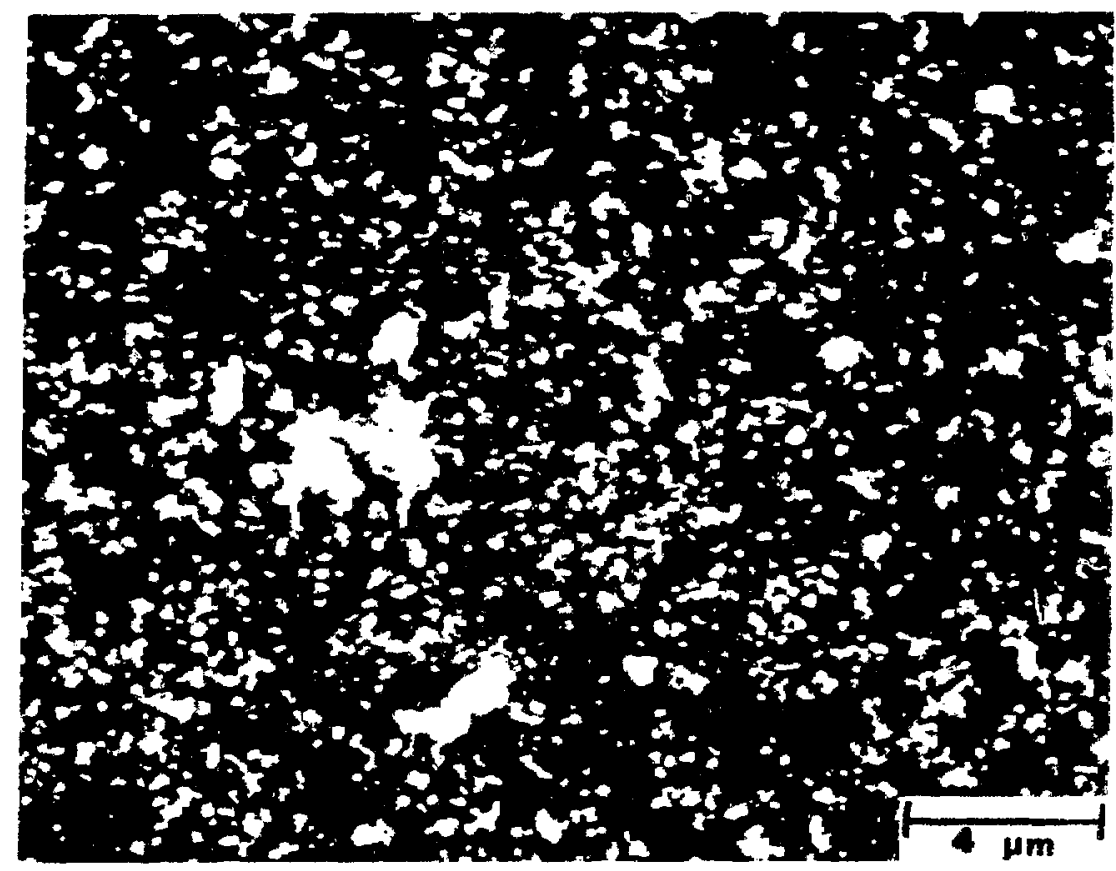

Figure 13. SEM Photomicrograph of NP0014 at 5000x.

43.3.5. Andersen Cascade Impactors, Model 2000 Mark II. These impactors were used for collecting and quantifying the particle size distribution of the airborne particulate material and total dust concentration in the range of 10-0.4- $\mu \mathrm{m}$ aerodynamic diameter. Ten desiccated/weighed Gelman DM800, 81-mm polyvinylchloride-acrylonitrile copolymer membrane filters were used on the preseparator, on impactor stages 0-7, and as the final or back-up filter (Fig. 14). A handtruckmounted vacuum pump (with 3/4-HP motor and dual manifold) was used to draw air through the impactor sample sets. A calibrated 10 liters/revolution Singer Dry Gas Meter was used for calibrating the impactor/vacuum pump before each sampling session. Figure 15 shows the impactor and vacuum pump in Demonstration Drift. (This figure clearly shows the airbome dust.)

4.3.3.5.1 Respirable Size Analysis By Cascade Impactors. The data for these samples are found in Appendix D-6. Table XIV indicates the date and location of the sample sets.
The particle size distribution was determined with the Model 2000 Andersen Cascade Impactor, operated at 1 acfm flow rate, with flow calibrations conducted at the sampling site preparation area.

A computer program designed for reducing raw impactor data was used in the analysis. It takes into consideration the reduced atmospheric pressure (from sea level) that affects the "slip" of the particle as it goes through the impactor jet. Log-probability graphs of the diameter versus cumulative percent values were prepared for each sample. Figures 16a and $b$ show the log-probability graph and the chart of the data generated by the computer program. The data for AC-2 did not fit a log-nomal distribution and indicated a possible bimodal distribution. This result is attributed to the large number of diesel particles found on the latter stages and final filter of the impactor samples. Such amounts are commonly found in mine and underground environments where diesel engines are used.

For AC-1 in Demonstration Drift, the particle size distribution ranged from 1.9- $\mu \mathrm{m}$ to $3.8-\mu \mathrm{m}$ mass median aerodynamic diameter (mmad) with a 


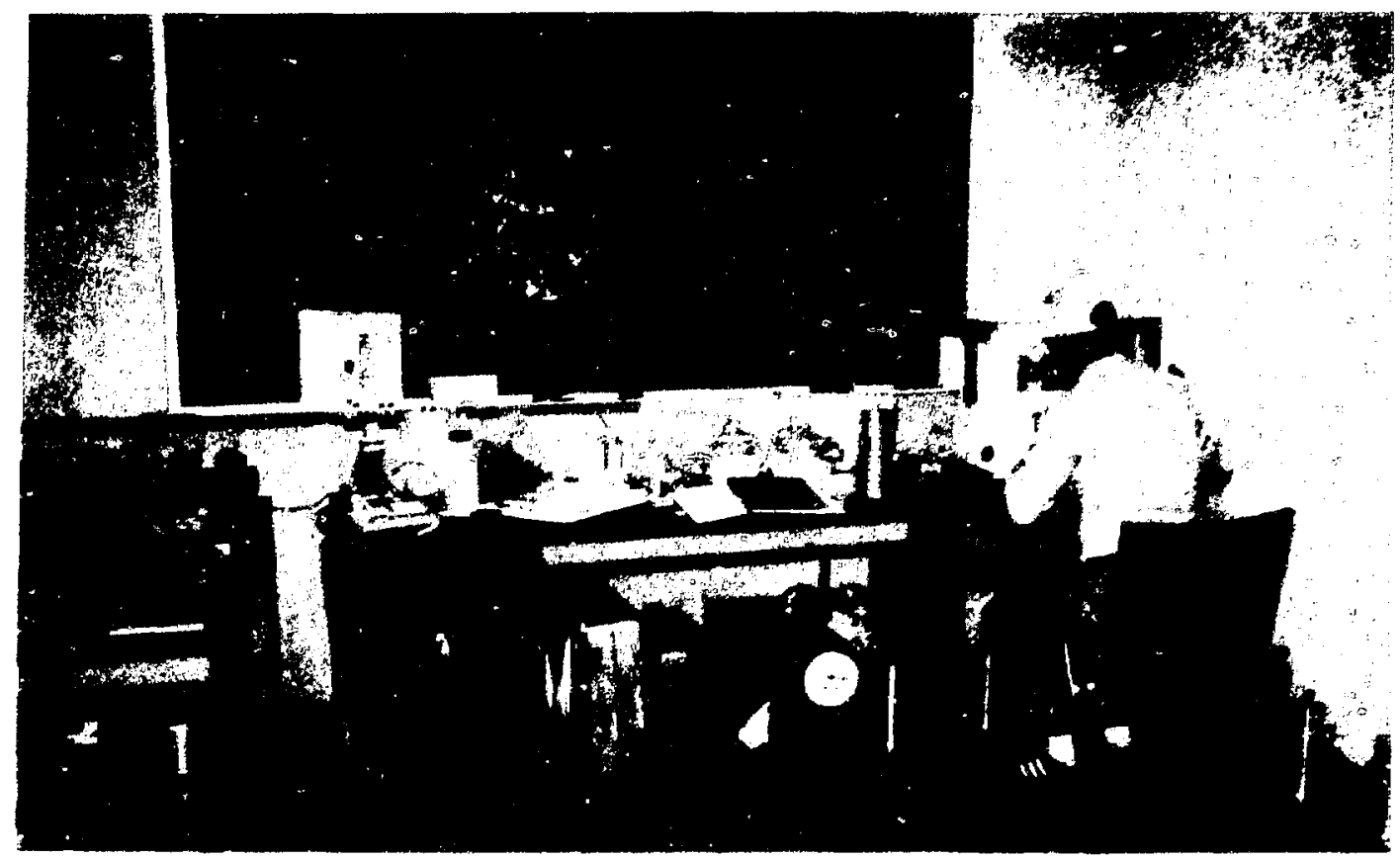

Figure 14. Investigator preparing impactor filters.

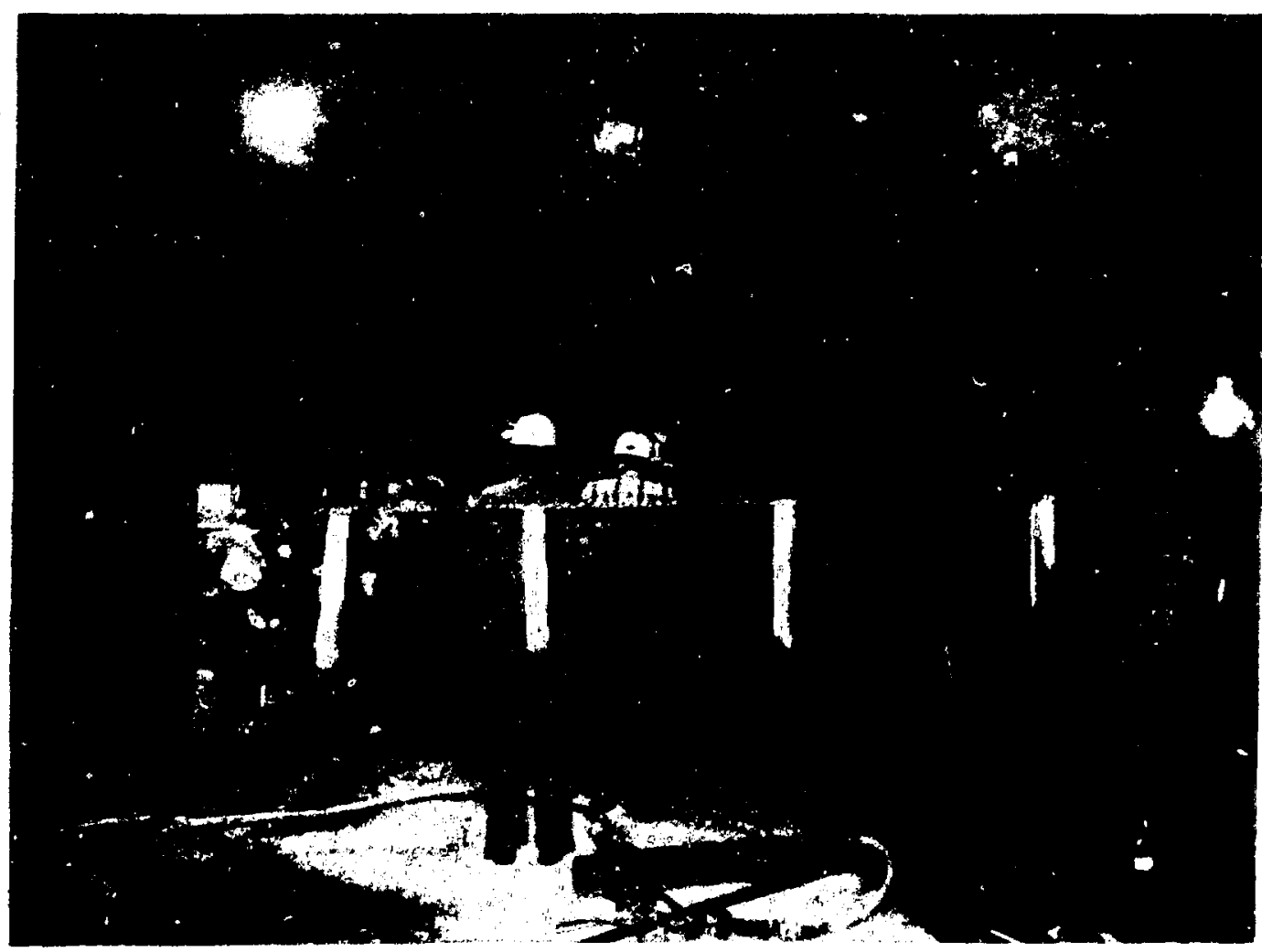

Figure 15. Cascade impactor (mid right) and vacuum pump (lower right) in Demonstration Drift. 
TABLE XIV

CASCADE IMPACTOR SAMPLING LOCATIONS

\begin{tabular}{lcc}
\hline Sample & DM & \\
Date & Filter & Sampling Location \\
\hline
\end{tabular}

AC-1

$03 / 23 / 88$

DM 06A Left side Demonstration Drift, approximately 12 ft from face

$03 / 23 / 88$

DM 05A

Right side Demonstration Drift, approximately $12 \mathrm{ft}$ from face

$03 / 24 / 88$

DM 07A

$03 / 24 / 88$

DM 08A

$03 / 24 / 88$

DM 03A

$03 / 25 / 88$

DM 04A

$03 / 29 / 88$

DM 02A

$03 / 29 / 88$

DM 01A

BACKGROUND-Demo. Drift-Muckers recently in main tunnel BACKGROUND-Demo. Drift-Muckers recently in main tunnel (Negative weights for all but final stage, UNUSABLE) Left impactor position ( $12 \mathrm{ft}$ from Demo. Drift face) Left wall, approximately $12 \mathrm{ft}$ from Demonstration Drift face

$\mathrm{AC}-2$

$04 / 14 / 88$

DM 10A

Right wall, approximately $12 \mathrm{ft}$ from Demonstration Drift face

$04 / 19 / 88$

DM 09A

Center of Laser Drift, approximately $15 \mathrm{ft}$ from face

$04 / 19 / 88$

DM 12A

(Negative weights for Stages 2-7, UNUSABLE DATA)

04/20/88

DM 13A

$04 / 20 / 88$

DM 14A

(Negative weights for Stages 1-7, UNUSABLE DATA)

$04 / 21 / 88$

DM 15A table and drill

Between laser core hole and DCT, near wall

Center of Laser Drift, approximately $15 \mathrm{ft}$ from face 
Figun.16.

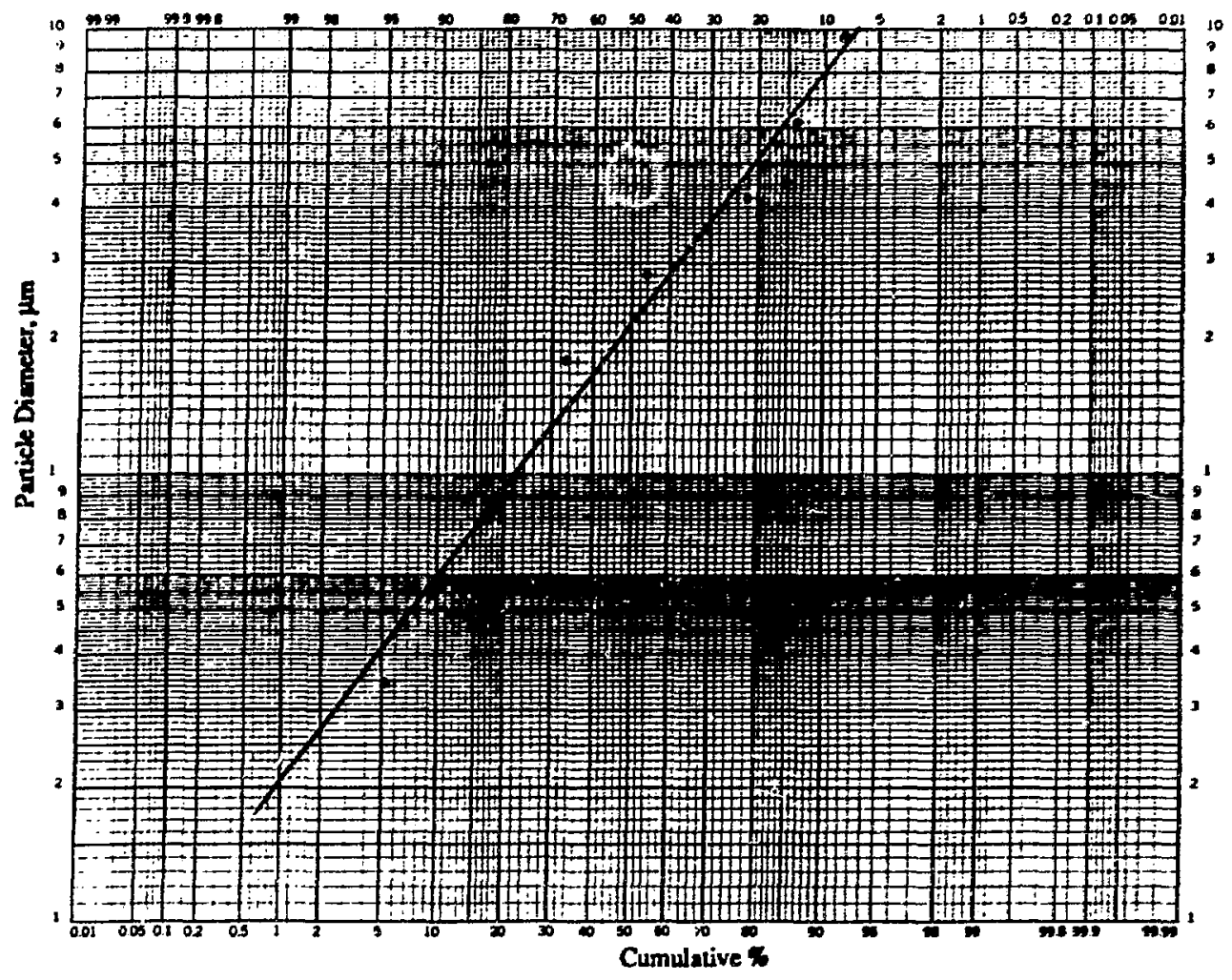

(a) Log Probability Graph of Sample DM-SA

compared to computer results.

$\mathrm{MMAD}=2.25260 \mu \mathrm{m}$

DELTA $=0.30240 \mu \mathrm{m}$

SIGMA $=2.77644$

CORREL. 4 TION $=0.99146$

INPACTOR CONCENTRATION IS $3.53 \mathrm{mg} / \mathrm{m}^{3}$

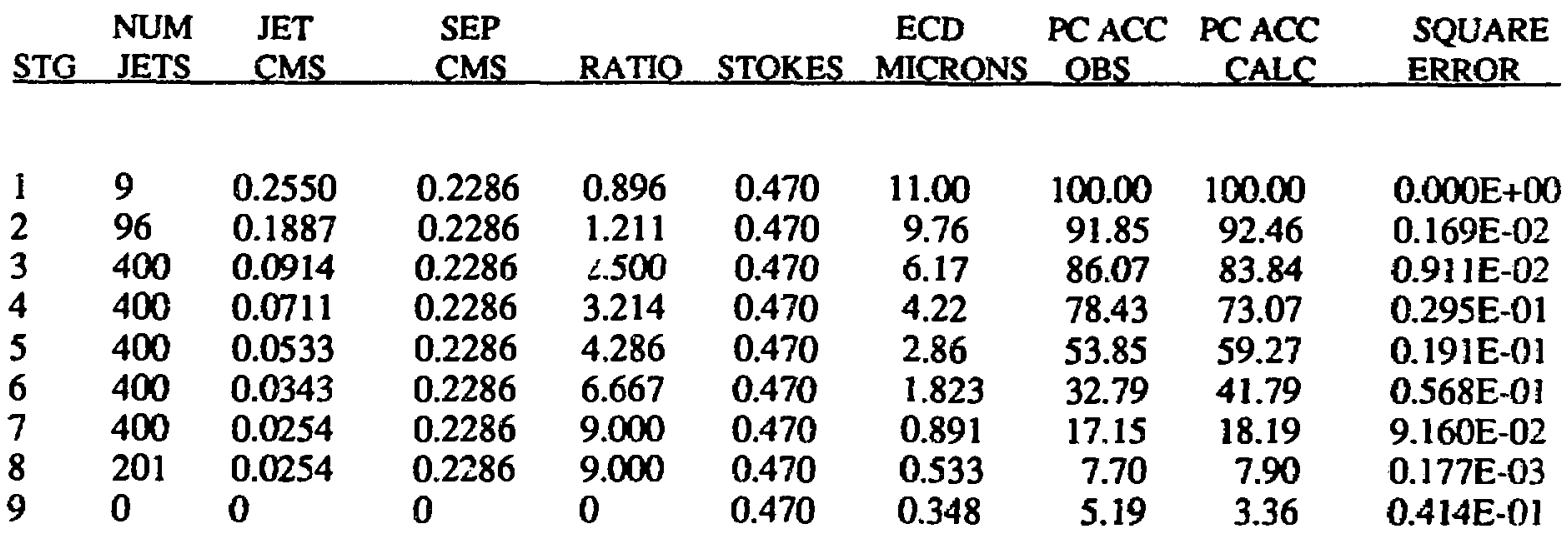


geometric standard deviation sigma of 2.5-3.8. Gross concentrations averaged $3.37 \mathrm{mg} / \mathrm{m}^{3}$.

For AC-2 in Laser Drift, the particle size distribution ranged from $0.97-\mu \mathrm{m}$ to $1.47-\mu \mathrm{m} \mathrm{mmad}$ and had a sigma of 6.06-9.8. Gross concentrations for $A C-2$ samples averaged $0.57 \mathrm{mg} / \mathrm{m}^{3}$.

These impactor samples indicate a significant number of particles smaller than $0.4 \mu \mathrm{m}$, as shown by the high percentage of the total amount of aerosol collected on the final filters. Many of these smaller particles are identified as diesel exhaust particles. Diesel exhaust particles are found in the 0.25 -to $0.26-\mu \mathrm{m}$ size range and thus would not affect any of the Andersen impactor stages. ${ }^{23}$ Any further particle sizing or separation would require additional sampling with equipment appropriate for this size range.

Samples from AC-2 contained smaller particles. This condition may be attributable to the lower dust level and the influence of the diesel exhaust paricle size. The "mucker" (without an exhaust scrubber) operated more frequently in the vicinity of $\mathrm{AC}-2$ during sampling. The ventilation of Laser Drift was such that more of the diesel particles and fine floor dust raised by the mucker were carried into the AC2 area during sampling than into the $\mathrm{AC}-1$ area.

\subsection{Conclusions from the Impactor} Data. Dry (air) coring generates a small dust particle. Eighty-six to ninety percent of the gross concentration is within the respirable range as described by Hines. ${ }^{24}$ The lower dust levels observed in $\mathrm{AC}-2$ are attributed to the progressively implemented dust control measures designed into the dust collection system. Some emission still occurred but at a much lower concentration.

\section{ON-SITE OBSERVATIONS}

Shortly after air coring of AC-1 began, dust emissions vented from around the DCT collar and from the attachment position of the plastic cuttings/collection bag at the bottom of the dust collector. All personnel in the drill area were wearing required safety equipment, including Mine Safety Appliance (MSA) Ultravue powered airpurifying respirators (PAPRs) (Figure 17). The REECo industrial hygiene measurements showed this dust emission to be approximately $22 \mathrm{mg}^{3} \mathrm{~m}^{3}$ with the Mini-Ram (a hand-held, light-scattering photometer). 18 LANL drilling personnel had expected initial leaks in the DCT system, but they did not know what the severity would be. The drilling was stopped. The tunnel exhaust system cleared the dust from the area within 5-10 min.

To modify the DCT collar, the LANL drilling consultant designed rubber rings (approximately 6in. diam) to act as seals when placed tightly between the collar and the drill stem. The seals were constructed by on-site REECo personnel. Additional dust control was provided by an 8-in-diam exhaust duct extended from the main tunnel exhaust line positioned in front of the collar to capture any subsequent fugitive dust emissions. A second 8-indiam duct was placed at the top vent of the dust collector to capture and exhaust any emissions from this area. The airflow of the 8-in. lines was measured at $380 \mathrm{cfm}$. The second emission site was sealed by securely taping the metal clamp and top of the cuttings/collection bag to the $\mathrm{DCT}$ cyclone.

During $A C-1$, the DCT cleaning procedures were developed and modified as needed. At prescribed intervals, the driliing helper reduced the DCT intake air and turned on the air to the two NCT vibrators (air-activated) ball bearings within a race, which shook the 18 secondary-stage filter bags inside the upper DCT section, allowing the accumulated dust to fall down through the cyclone (bottom section) and into the plastic cuttings/ collection bag. Also, the helper vigorously pounded on the DCT's externai shell with a hammer to assist the vibrators. The pounding increased the high noise level of the unit. Manual fluctuation of the DCT pressurizing air also helped clean the filters. A procedure was also developed for changing the DCT plastic cuttings/collection bags. Industrial hygiere suggested closing and securing the filled bag before removal from the bottom of the DCT to decrease the potential for emissions from the open bag.

\section{RESULTS AND CONCLUSIONS FOR G- TUNNEL PROTOTYPE AIR CORING}

(1) SEM/EDX and XRDA are required for specific identification/quantification of the fibrous zeolites, erionite, and mordenite.

(2) Cleaning the collection equipment and disposing of collected material (dust) are labor intensive and require care to avoid area contamination and personnel exposure. 


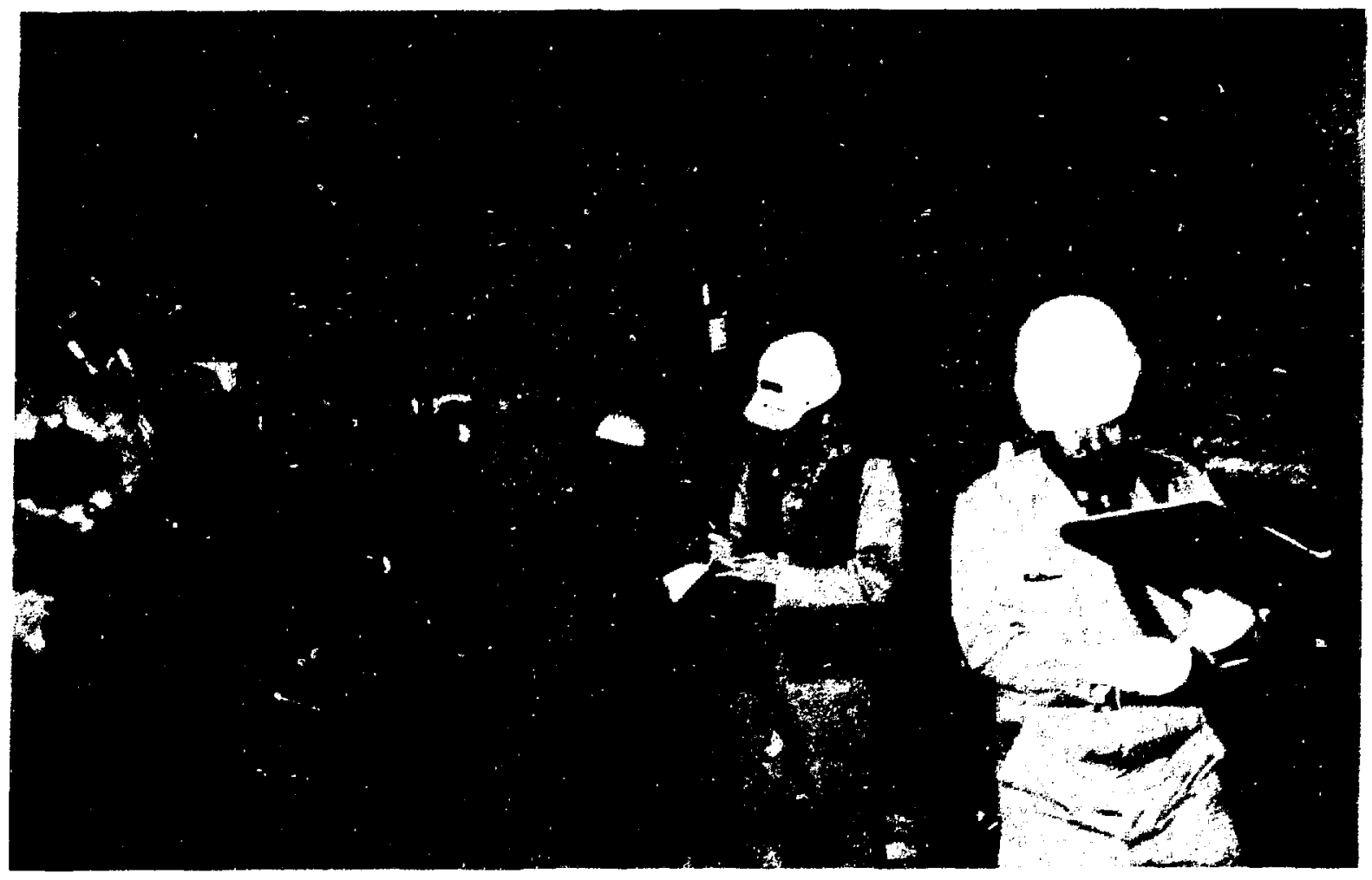

Figure 17. Personnel in AC-1 are wearing PAPRs and air-monitoring equipment.

(3) A supplementary exhaust system is required (a) to remove emissions from the air cleaner, (b) to control fugitive emissions, and (c) to provide dilution ventilation to the area.

(4) Modifications to the dust collection system reduced the measured respirable dust mass from an average of $1.02 \mathrm{mg} / \mathrm{m}^{3}$ during $\mathrm{AC}-1$ to $0.27 \mathrm{mg} / \mathrm{m}^{3}$ for $\mathrm{AC}-2$.

(5) Crystalline silica analysis detected no cristobalite or tridymite. One quartz positive $\left(0.04 \mathrm{mg} / \mathrm{m}^{3}\right)$ was detected, and four quantities $\left(0.02 \mathrm{mg}^{3} \mathrm{~m}^{3}\right)$ were within the level of detection and quantification of the analytical instrumentation. When 8-hour TWAs were calculated for these samples, they were below the ACGIH TLV/TWA for quartz $\left(0.1 \mathrm{mg} / \mathrm{m}^{3}\right)$ because of the short duration of the drilling operations (Table VI). Analysis of the bulk samples from both core holes shows available quartz in the bagged dust from the DCT. The very low quantities reported in the air particulate samples indicate that the modified dust control system was efficient when it functioned properiy. Crystalline silica was not a significant problem during air coring of $\mathrm{AC}-1$ and $\mathrm{AC}$ 2. However, quartz could become a problem if air coring operations are extended to 8-hours at the observed concentrations and efficient dust collection systems are not used and maintained properiy.

(6) Zeolite fibers were not detected in AC-1 and AC-2 airbome particulate samples collected during air coring.

(7) The dust control system in the sampled configuration was effective. The dust control system is defined as the electric drill, AtlasCopco DCT, the G-Tumel exhaust ventilation system, the G-Tunnel Safety and Health work practices, etc. 
(8) Diesel particulates from vehicles working in the G-Tunnel area were detected. Vehicle exhausts should be controlled to maintain acceptable air quality (on a case-by-case basis). NOSH has recommended that "Diesel exhaust should be regarded as a potential occupational carcinogen on the basis of evidence from available studies, and employers should take steps to limit worker exposure to the greatest extent feasible." 25

\section{RECOMMENDATIONS FOR EXPLORA- TORY SHAFT FACILITY AT YUCCA MOUNTAIN (TASK 4)}

Based on the findings presented in this report, we recommend that the following be implemented in future drilling activities.

(1) General dilution ventilation must be provided to the drilling site to control employee exposures to fugitive dust and vehicle emissions.

(2) Local exhaust ventilation must be provided on major emission sources (e.g., drill stem/collar opening).

(3) Air supplied to the drill hole must be balanced at all times with the dust collection equipment. (Imbalance creates excess emissions.)

(4) Area employees (workers and investigators) must be fitted for, provided with, and trained to wear air-purifying respirators. The respirators would be used only in emergency situations when the worker or investigator is required in the area during large emissions.

(5) Dust control equipment, equivalent to or superior to the Atlas-Copco DCT, should be in operation during any dry or air drilling activity. (Dust collection principles employed by these devices apply to all particle shapes.)

(6) Dust collection equipment should be used as part of and exhausted to the local exhaust ventilation system.
(7) All potential emission sources should be identified in advance of drilling, and emission control strategies developed. This recommendation should be implemented on a case-by-case basis because emission sources will vary from site to site.

(8) Air particle sampling and analysis should be provided to evaluate the effectiveness of the controls.

(9) Dust collection equipment should be tested before start-up and monitored periodically throughout drilling to ensure adequate performance.

(10) Vehicle exhausts should be kept as low as reasonably achievable (by routine vehicle tuneups, addition of scrubbers, good local exhaust, or dilution ventilation).

(11) All equipment should be correctly maintained and kept in working order. No drilling operations should be conducted if dust collection equipment is not functioning properly.

(12) Safe operation procedures should be developed and implemented to ensure continued safe operation of equipment.

(13) Employees should be trained before they begin the job and during the job to perform their work such that emissions and exposures are minimized.

(14) Contingency plans should be developed in advance to cope with equipment failures. Such plans should include the shutdown of drilling operations in the event that control equipment (i.e., tunnel ventilation) systems fail.

(15) Drilling operations should adhere to existing health and safety requiremeits applicable to the site (e.g., REECo and Mine Safety and Health Association requirements).

(16) One should not conclude that zeolite fibers do not exist because they were not detected in the limited sampling data collected from 
air coring tests in G-Tunnel tuffs. The potential hazand to personnel working in the Yucca Mountain area (based on geologic mapping) mandates that similar sampling and analysis for fibrous zeolites, especially mordenite, be performed during drilling at Yucca Mountain to determine the hazards and appropriate protection for personnel.

(17) Animal inhalation studies with fibrous mordenite (identified as being one of the primary zeolites in the Yucca Mountain tuffs) should be conducted to determine the biological effects of this fibrous zeolite.

\section{ACKNOWLEDGMENTS}

We wish to express our thanks to Barbara Carlos, David Bish, and David Broxton (all of ESS1) for their assistance in obtaining and analyzing zeolite samples and reference/comparative materials for the bulk sample task; to Am Pendergrass (Los Alamos Technical Associates) for in-depth quality assurance assistance; to Richard Grisham (REECO) for the loan of his instruments and assistance in microscopy; to Allan R. Frazier and the REECo Industrial Hygiene section for IH assistance at G-Tunnel: to Ed Kress of the REECo calibration laboratory for his quick response to our requests for on-site equipment calibrations; to LaVell Atkinson and the REECo G-Tunnel crew for all of their help, too lengthy to discuss; and to John Talbutt and the other Sandia pensonnel for project preparation space and support. Many thanks to Harriett Allen (ESSDO editor) and Susie E. Medina (HSE-5) for editorial time. A special thanks goes to Brenda $\mathrm{E}$. Pacheco (HSE-5) for the many tedious hours spent in the preparation of this report. 


\section{REFERENCES}

1. (a) P. Montazer, 1985, "Rationale for Air Drilling/Coring in the Exploratory Shaft and Test Chambers" (6 page draft), and "Preliminary Outline of Design Needs for Prototype Air Coring Tests in GTunnel" (5 page draft), personal communication from P. Montazer, USGS/Nuclear Hydrology Program, to P. Aamodt, Los Alamos National Laboratory, providing input for planning the Prototype Air Coring Test.

(b) P. Montazer, 1985, personal communication from P. Montazer, USGS/Nuclear Hydrology Program to P. Aamodt, Los Alamos National Laboratory.

(c) P. Monta rer, 1986, personal communication from P. Montazer, USGS/Nuclear Hydrology Program to M. Blanchard, Department of Energy/Waste Management Project Office.

2. J. M. Ray and J. C. Newsom, 1987, "Prototype Test Plan 6.1, Prototype Air-Coring, WBS 1.2.6.9.4.6.1.A," submitted to the Department of Energy/Waste Management Project Office (TWS-ESS-1-7/87-11).

3. D. L. Bish and D. T. Vaniman, "Mineralngic Summary of Yucca Mountain, Nevada," Los Alamos National Laboratory report LA-10543MS (October 1985).

4. C. Maltoni, F. Minard, and L. Morisi, "Pleural Mesotheliomas in Sprague-Dawley Rats by Erionite: First Experimental Evidence," Environ. Res. 29 238-244 (1982).

5. J. C. Wagner, J. W. Skidmore, and D. M. Griffiths, "Erionite Exposure and Mesotheliomas in Rats," Br. J. Cancer 51727 730 (1985).

6. N. F. Johnson, R. E. Edwards, D. E. Munday, N. Rowe, and J. C. Wagner, "Pluripotential Nature of Mesotheliomata Induced by Inhalation of Erionite in Rass," Br. J. Exp. Pathol. 65 377-388 (1984).
7. M. Artivinli and Y. I. Baris, "Environmental Fiber-Induced Pleuro-Pulmonary Diseases in an Anatolian Village: An Epidemiologic Study," Arch. Environ. Health 37 177-181 (1982).

8. M. Artivinli and Y. I. Baris, "Malignant Mesotheliomas in a Small Village in the Anatolian Region of Turkey: An Epidemiologic Study," J. Nat. Cancer Inst. 63 17-22 (1979).

9. Y. 1. Baris, A. A. Sahin, M. Ozemi, I. Kerse, E. Ozen, B. Kolacan, M. Altinors, and A. Goktepeli, "An Outbreak of Pleural Mesothelioma and Chronic Fibrosing Pleurisy in the Village of Karian/Urgup in Anatolia," Thorax 33 181-192 (1978).

10. M. F. Stanton and C. Wrench, "Mechanisms of Meosthelioma Induction with Asbestos and Fibrous Glass," J. Nat. Cancer Inst. 48 797-821 (1972).

11. Timbrell, V., "The Inhalation of Fibrous Dusts," in Annals of the New York Academy of Sciences, Conference Proceedings: Biological Effects of Asbestos, H. E. Whipple, Ed. John Wiley \& Sons, 1965, New York, Vol. 132, Art. 1, pp. 255-273.

12. L. B. Sand and F. A. Mumpton, "Natural Zeolites," in Mineralogy and Geology of Natural Zeolites, F. A. Mumpton, Ed., Pergamon Press, Vol. 4, pp. 1-15 (1981).

13. D. J. Burton and J. M. Ortega, "NNWSI Project-Element WBS-1.2.6.9.4.6.1-B, Interim Report on Dust Control Proposals," Los Alamos National Laboratory document LA-UR-88-321 (1988).

14. Los Alamos National Laboratory-Quality Assurance Manual for the Yucca Mountain Project, latest revision.

15. Los Alamos National Laboratory-MEC-8 Colibration Certificate for the "Bubble Generator (SN-751-S)" by Gilian Instrument Corp., MEC-8/File \#5347, February 19, 1988. 
16. R. J. Beckman, Los Alamos National Laboratory, Group A-1, personal communication/calculation or the estimated mean and standard deviation for the Gilibrator, March 2, 1988.

17. "Industrial Hygiene Field Operations Manual," Occupational Safety and Health Administration, CPL 2-2.20A, Office of Health Compliance Assistance, October 29, 1984.

18. NIOSH Method 7500: "X-Ray Powder Defraction Method for Silica Analysis," February $15,1984$.

19. (a) J. C. Maloney and A. R. Frazier, "Dry Drilling at G-Tunnel," REECo memorandum JCM:5/46:1rd to R. F. Pritchett, (April 28, 1988).

(b) J. C. Maloney and A. R. Frazier, "Dry Drilling in Laser Drift at G-Tunnel," REECo memorandum to R. F. Pritchett (June 13, 1988).

20. NIOSH Method 7400, "Membrane Filter Method for Evaluation Airbome Asbestos Fibers, "Rev. 3, September 15, 1987.

21. J. R. Connolly and K. Keil, "Field, Petrographic, and Geochemical Relations of the Grouse Canyon Member of the Belted Range Tuff in the GTUF Rock Drift Test Area, U12g Tunnel, Nevada Test Site," Sandia National Laboratories report SAND84-7206 (1985).

22. "Threshold Value Values and Bioligical Indices for 1987-88," American Conference of Govemmental Industrial Hygienists Publication Office, Cincinnati, OH, 1987.

23. Y. S. Cheng, H. C. Yeh, I. L. Manderly, and B. V. Mokler, "Characterization of Diesel Exhaust in a Chronic Inhalation Study," Amer. Ind. Hyg. Assoc. J. 45 547-555 (1984).

24. W. C. Hinds, "Aerosol Technology Properties Behaviors and Measurement of Airbome Particles," John Wiley, 1982.
25. NIOSH Intelligence Bulletin, "Diesel Exhaust May Be Carcinogenic, Exposure Should Be Controlled," August 1988. 


\section{APPENDIX A \\ ESTIMATES OF EXPECTED EXPOSURE CONCENTRATION TO DRILL DUST}

Unfortunately, there is little information with which to quantify the emission sources, except for fugitive emissions from the dust collector.

Terms used in calculation are defined below:

$\mathrm{w}_{\mathrm{f}}=$ emission to air $\left(\mathrm{mg} / \mathrm{m}^{3}\right)$

C = concentration of dust in air $\left(\mathrm{mg} / \mathrm{m}^{3}\right)$

$\mathrm{K}$ = mixing factor (unitless)

$W_{t}$ = weight of rock drilled out of hole (does not include rock core) (mg/min)

$\mathrm{W}_{\mathrm{s}}=$ weight of rock material collected in preseparators $(\mathrm{mg} / \mathrm{min})$

$\mathrm{W}_{\mathrm{c}}=$ weight of dust collected in air cleaner $(\mathrm{mg} / \mathrm{min})$

$\mathrm{N}=$ efficiency of air cleaner (unitless)

$D_{2}=$ outside diameter of drilled material (in.)

$D_{1}=$ outside diameter of core (in.)

L = length of drilled core (in.)

t = time of drilling (min)

S.G. = specific gravity of rock (water)

$\mathrm{Q}_{\mathrm{S}}=$ air supplied to the drill area (actual $\mathrm{ft}{ }^{3} / \mathrm{min}$ )

$Q_{r}=$ air retumed (or exhausted) from the drill area (acfm)

Vol = volume of air in tunnel between drill face and some distance back from the face $\left(\mathrm{ft}^{3}\right)$

$h$ = height of tunnel ( $\mathrm{ft}$ )

f $=$ length of tunnel (ft)

$\mathbf{T}=$ temperature of tunnel air $\left({ }^{\circ} \mathrm{F}\right)$

d $=$ density correction for air at temperature and pressure (unitless) 
Estimated values of the input terms, obtained from manufacturer's data and from drill operations descriptions, are summarized below:
$K=\mathbf{0 . 8 0}$
S.G. $=3$, unitless
$\mathrm{L} / \mathrm{t}=0.60 \mathrm{in} . / \mathrm{min}$
$\mathrm{W}_{\mathrm{s}}=0.9 \mathrm{Wt} \mathrm{mg} / \mathrm{min}$
$D_{1}=2.5$ in.
$Q_{\mathrm{S}}=Q_{\mathrm{r}}=3500 \mathrm{acfm}$
$D_{2}=3.79$ in.
$h=20 \mathrm{ft}$
$T=65^{\circ} \mathrm{F}$
$f=30 \mathrm{ft}$
d $=0.80$
$\mathbf{N}=99.5 \%$

The following equations were used to estimate $C$, the expected airbome concentration of dust in air.

$$
\mathrm{C}=\frac{\text { Weightof Material Generator/Time }}{\text { ofume of Air }} \times \frac{1}{\mathrm{~K}}
$$

$\mathbf{W c}=\mathbf{W t}=\mathbf{W s}$

$W f=(W t-W s)(1-N)$

$\mathrm{W}_{\mathrm{T}}=0.0129(\mathrm{D} 22-\mathrm{D} 12) \frac{\mathrm{L}}{\mathrm{T}}(\mathrm{S} . \mathrm{G}) \times$.
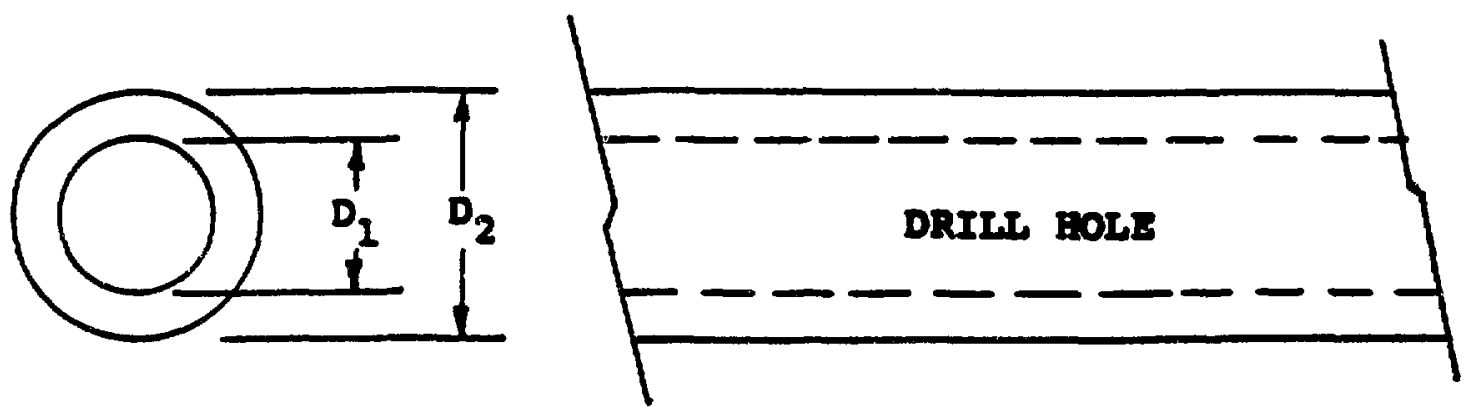


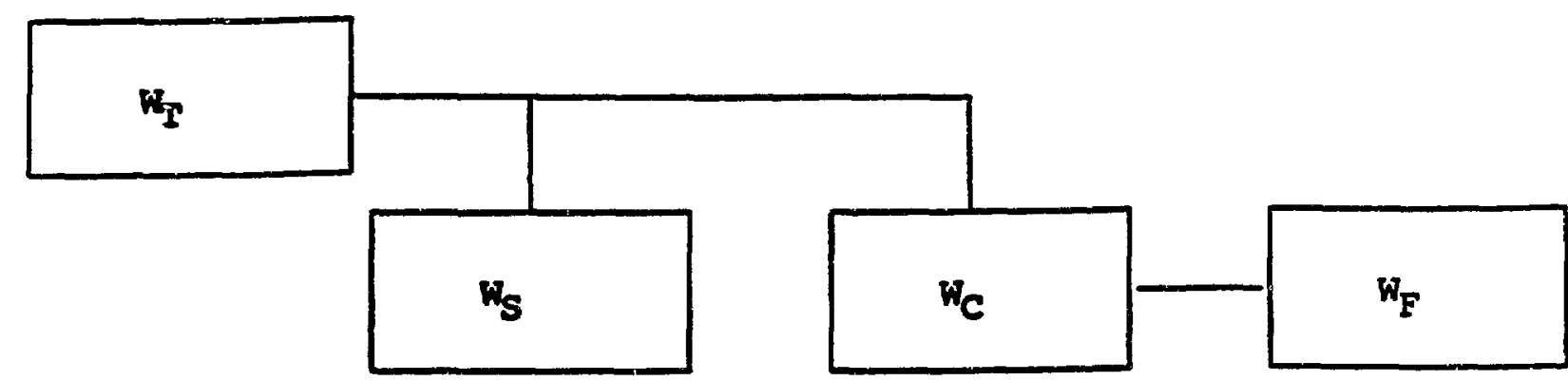

$W_{F}=0.0129(D 22-D 21) \frac{L}{T} \frac{S G}{10-6} W S(1-N)$

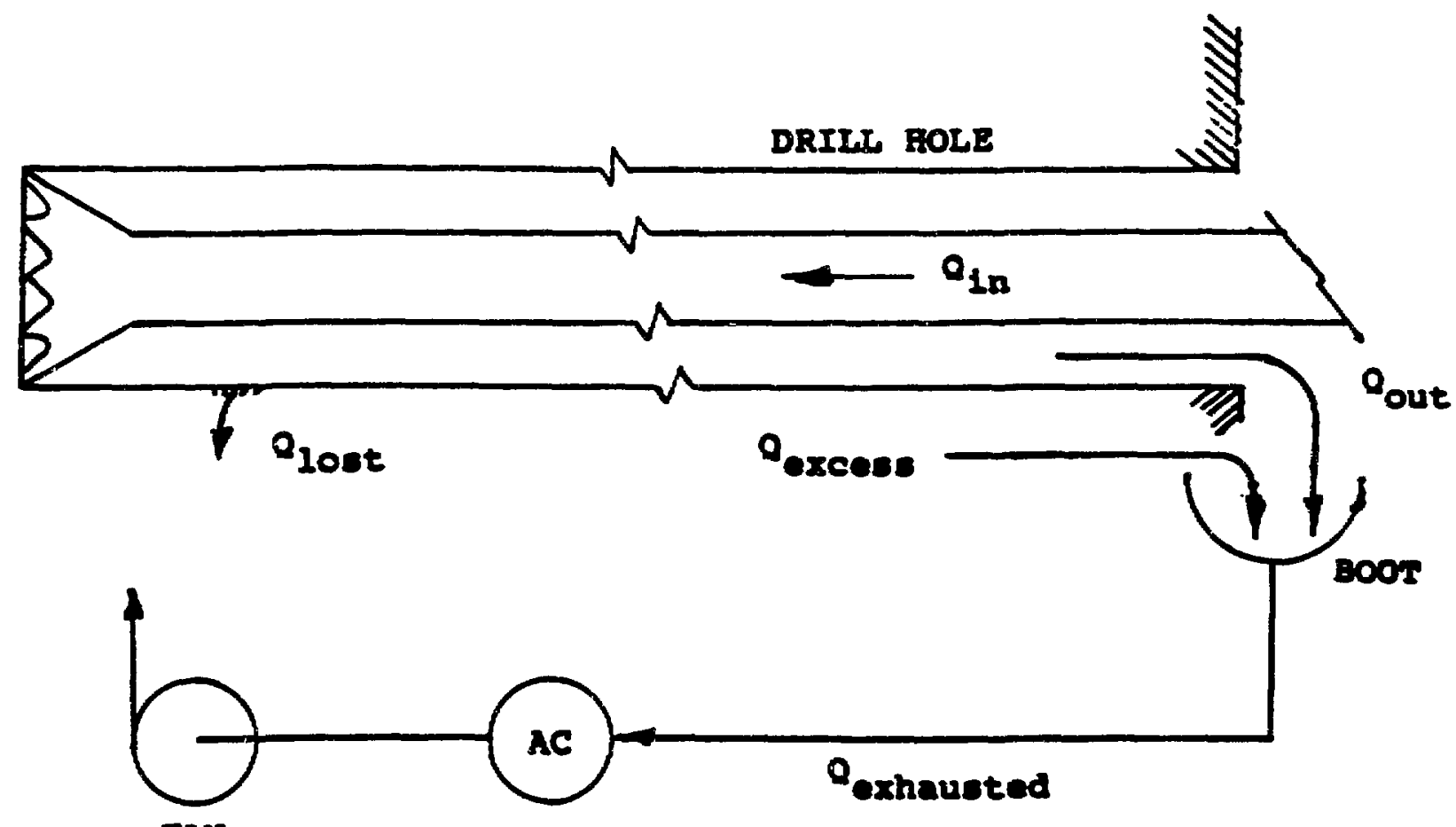

FA:

and

$Q_{\text {OUT }}=Q_{\mathbb{N}}-\mathbf{Q}_{\text {LOST }}$

Q EXHAUSTED $\mathbf{N}=\mathbf{Q}_{\text {OUT }}+\mathbf{Q}_{\text {EXCESS }}$ 


$$
\begin{aligned}
W_{T} & =0.0129(D 22-D 12) \quad \frac{L}{T}(S . G .) \times 106 \mathrm{in} . \frac{\mathrm{mg}}{\mathrm{min}} \\
& =0.0129(37902-2.52)(0.6)(3.0)(106) \\
& =0.1884 \times 106 \mathrm{mg} / \mathrm{min} \\
W_{F} & =(\mathrm{WT})(0.1)(1-0.995) \\
& =(0.1884 \times 106)(0.1)(0.005) \\
W_{F} & =94.2 \frac{\mathrm{mg}}{\mathrm{min}} \\
C & =\frac{\mathrm{mg} / \mathrm{min}^{2}(3.53)}{\mathrm{Q} \mathrm{S}} \times \frac{\mathrm{L}}{\mathrm{K}} \\
& =\frac{(94.2)(35.3)}{3500} \times \frac{1}{0.8} \\
& =1.2 \mathrm{mg} / \mathrm{m}^{3}
\end{aligned}
$$




\section{DCT units}

Like must Just removal equipment. DCT units have a suction houd which is positioned over the Jnll hole to suck up the dust. A hose transports the dust to a separation unit for accumulation. The necessary partial vasuum is created with an airpou ered ejector. ur. in cernain cases. with a fan. One basic design difference in difterent types of dust extractor equipment is the positioning of the ejector or lan. This positioning determines whether the ststem works with overpressure or with i partial vacuum. DCT dust collection equip. ment works with a partial vacuum throughout the entire system. The ejector or fan. which creates a partial vacuum. is positioned at the final stage. after the filter unit. This offers several advantages. including:

= no leakage of dust in the event of a hose leak or damage to the suction hose

= the ejector or fan operates in clean. fitered air. keeping wear to a minimum

= less load on the filters when the ejector is used. since the operative air of the ejector does not need to pass through the filters. nor come into contact with any oil that may be cuntained in the compressed air.

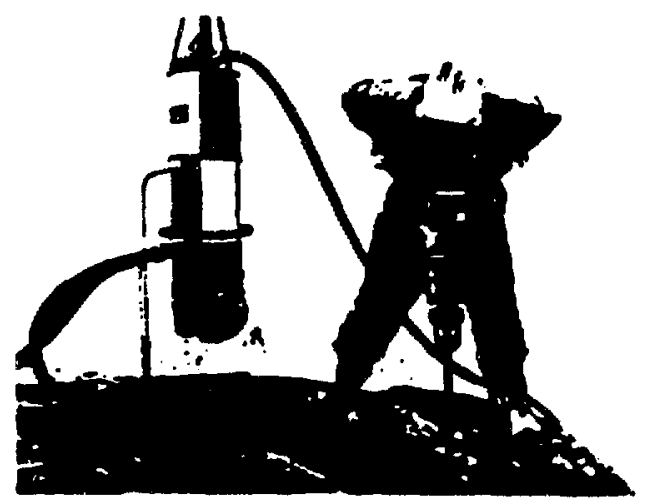

Fig. 19:45 Hend-notd rock drill with dust collecting equidment

\section{DCT separates almost all injurious stone dust}

In DCT equipment dust separation is a Iwo-stage process. A cyclone separales about $\%$ per cent of the stone dust. including all particles larger than 300 micrometres $(0.2$ millimetres) in size. The remainder of the dust. including the dangerous fine particles (less than 0.5 misrometres) is separated to practically 100 per cent in the filiration unit. The filters are encased inside a robust metal cuntainer. the lower part of which is designed as a coarse filter and where vital components are protected with anti-wear rubber. The cuntainer preyents mechanical wear and protects the filters during unfavourable weather conditions. It also houses the filter cleaning equipment and the drive cjector. On larger DCT unils. the cjector is posilioned on top of the container and can be replaced with a separately positioned centrifugal fan if preferred.

\section{DCT design features}

The smalter DCT units have a cylindricai sontainer which encases a number of hose filters. while the larger DCT units have rectangular sections containing fat filters. Separation of the dust in the hose fitters occurs internally. whereas the nat fil. ters separate the dust externally.

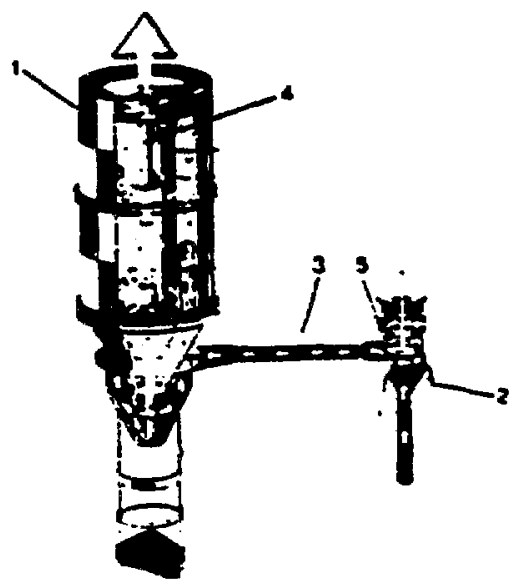

$\frac{\bar{亠}}{\frac{5}{6}}$

Fig. 19:46 DCT dust collecting equipment. smatter s120

1. seperator with hose fillers

2. suetion hood

3. suction hose

4. 9jector

5. brake apector 


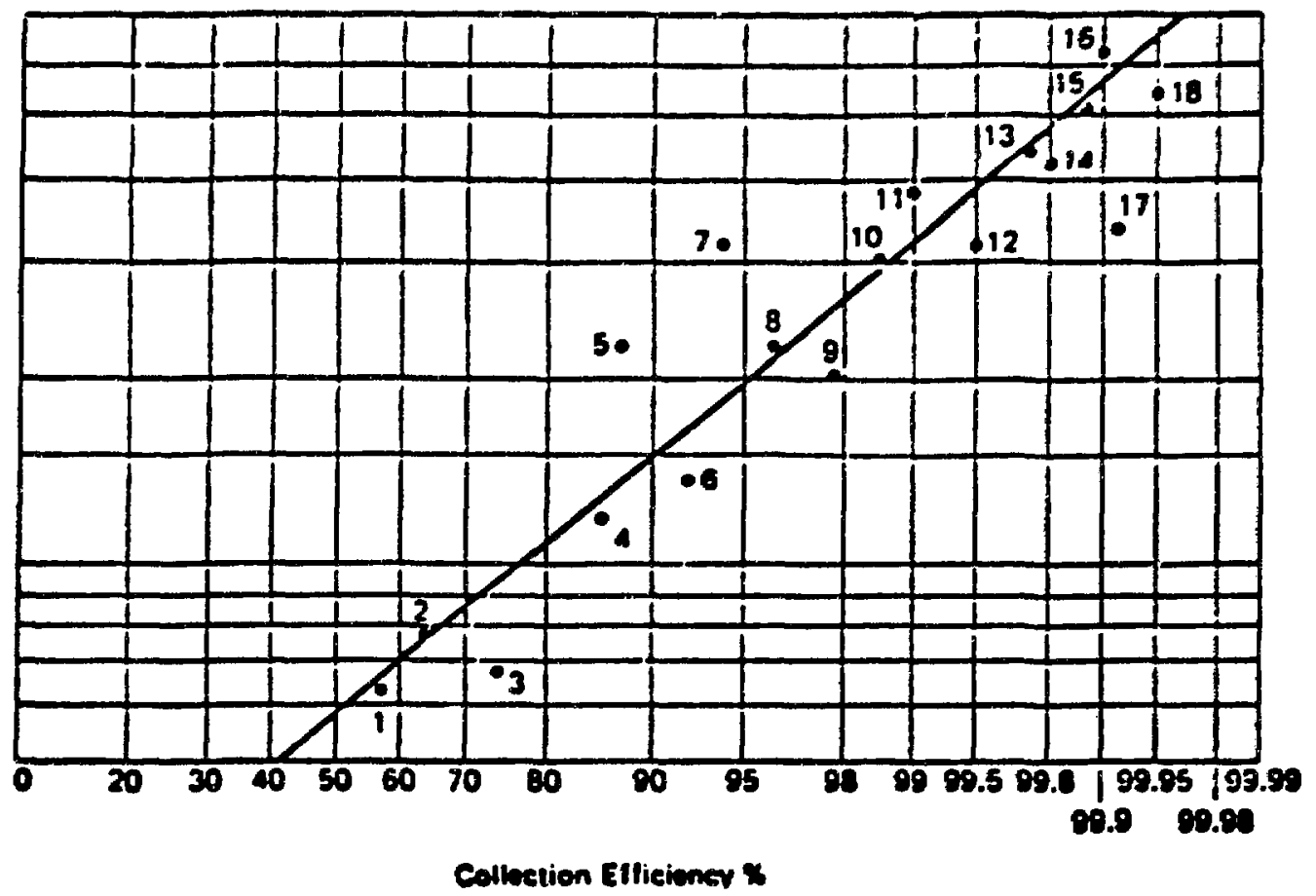

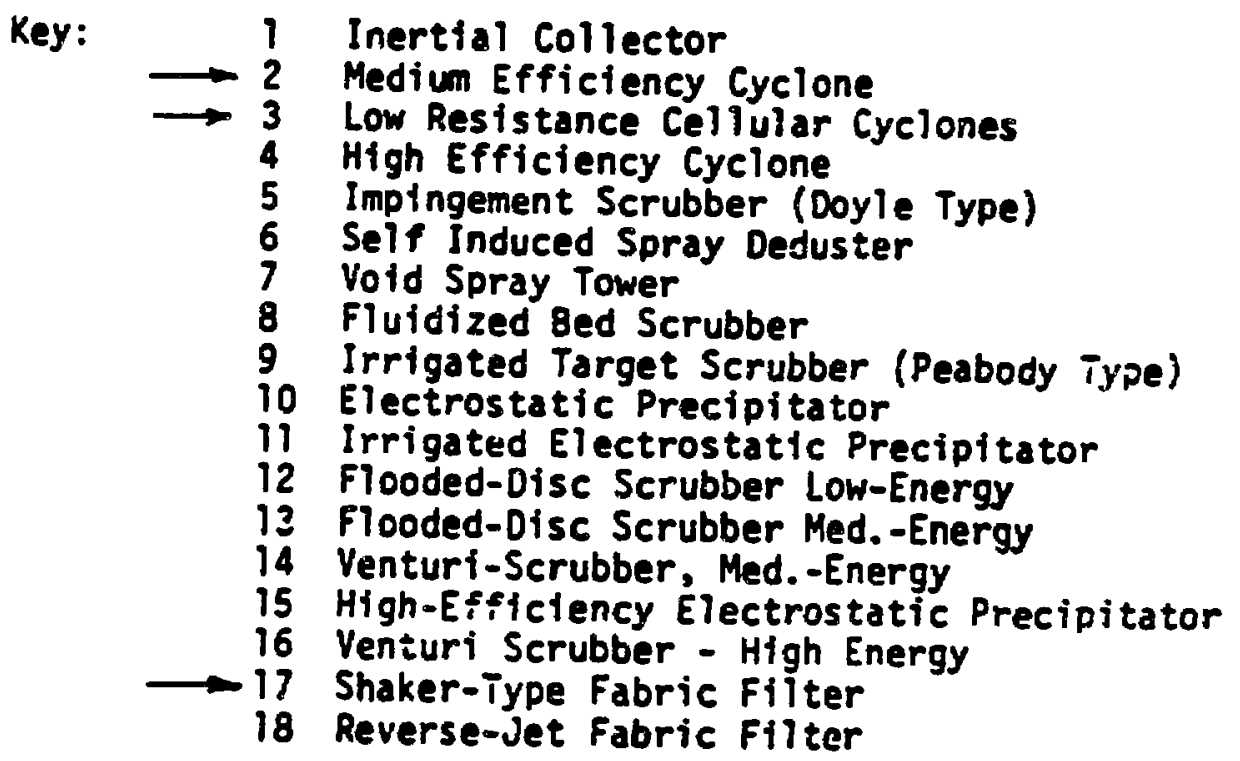

(from Stairmand) 


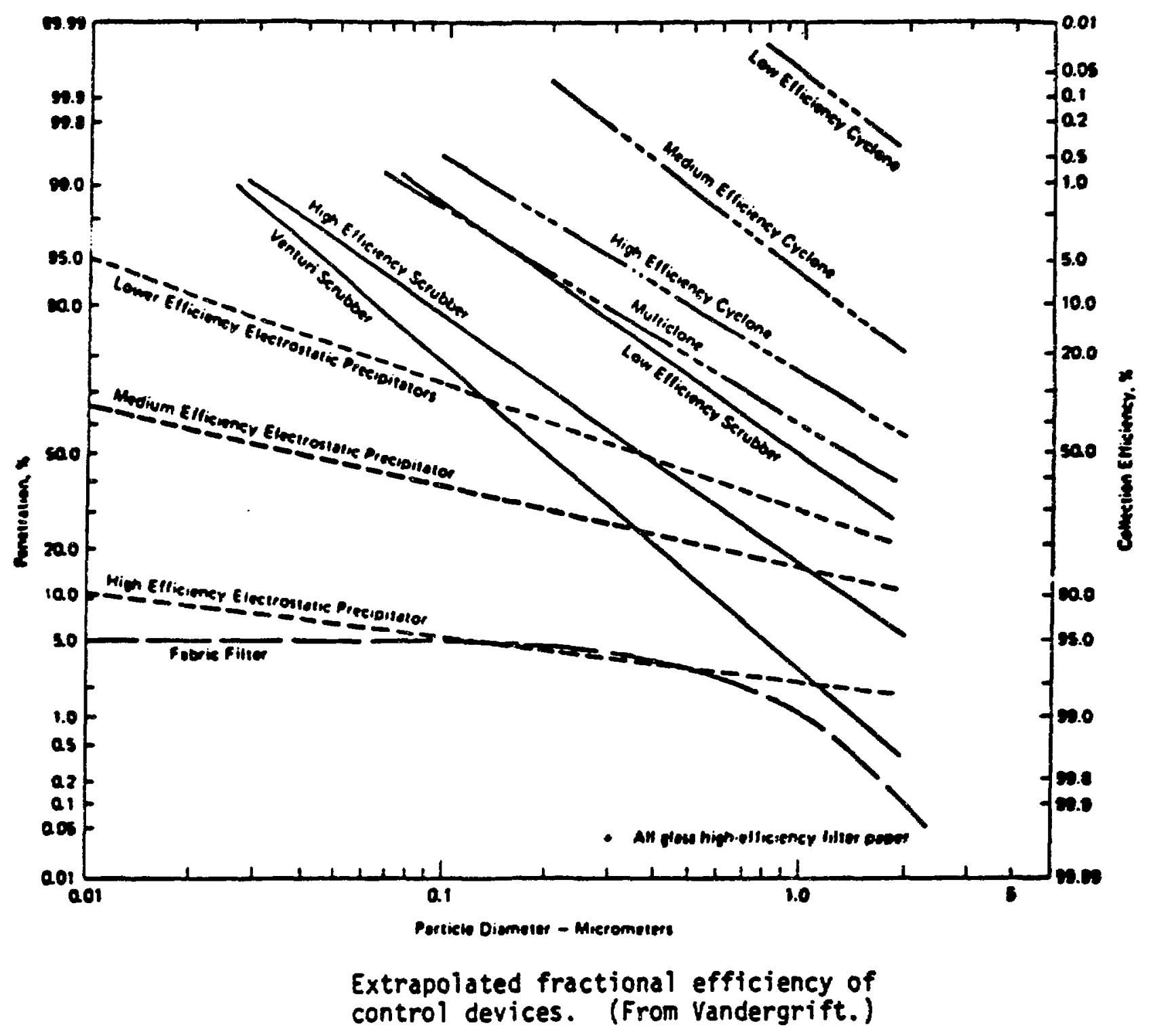




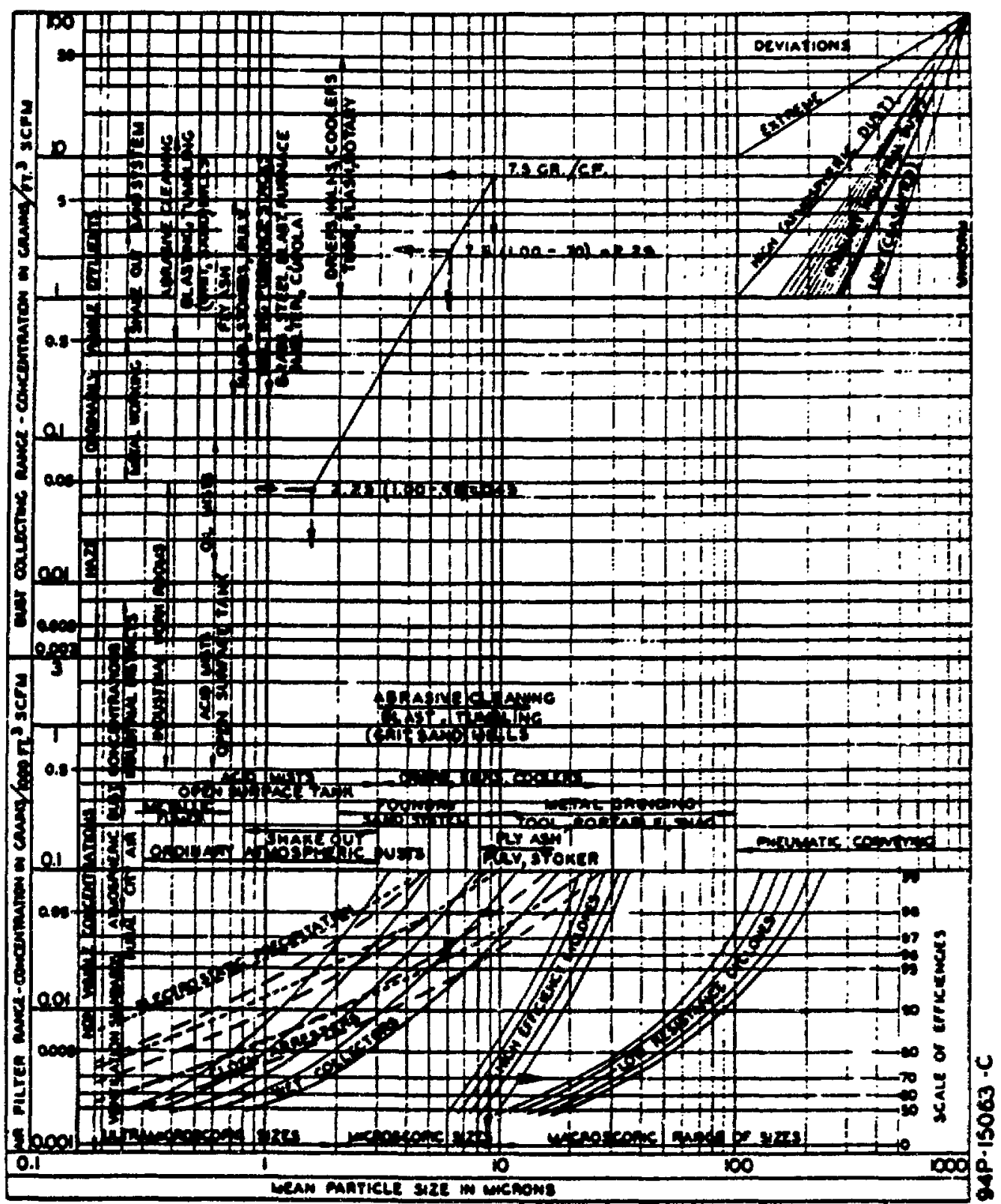

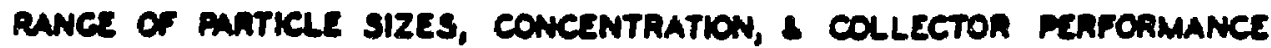

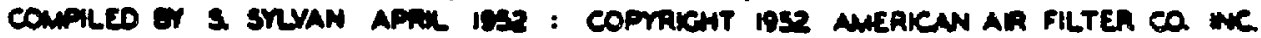

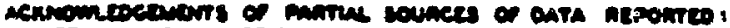

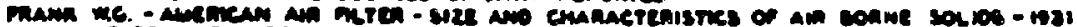

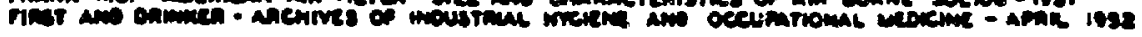




\section{APPENDIX C}

\section{DETAILED PROCEDURES}

DETAILED PROCEDURE

TWS-HSE5-DP-201 (R0)

TWS-HSE5-DP-202 R0

TWS-HSE5-DP-206 R0

TWS-HSE5-DP-211 RO

TWS-HSE5-DP-212 RO

TWS-HSE5-DP-213 R0

TWS-HSE5-DP-214 RO

TWS-HSE5-DP-215 RO TITLE

EFFECTIVE DATE

Air Particulate Sampling

11-06-87

Preparation Procedure for

SEM Evaluation.

Operating Instructions for 11-06-87

AMRAY Model 1000 Scanning

Electron Microscope and Kevex

Model 7000 Energy Dispersive X-Ray

Analyzer for Evaluation of Air

Samples Collected on Nuclepore Filters.

Fiber Counting Procedure.

09-21-87

Preparation and Use of Air

10-27-87

Particulate Filter Sampling Devices.

Preparation, Calibration and Use Cascade Impactors.

09-09-87

Procedures for the Calibration and

Use of SKC Personal Sampling Pumps.

Procedures for the Calibration and

09-21-87

Use of Alpha-1 Personal Sampling Pumps.

Procedures for the Calibration of the Singer Dry Gas Meter.

09-08-87

Copies of these DPs and all subsequent changes are contained in the Los Alamos National Laboratory Quality Assurance Documents for the Yucca Mountain Project 1988. 
APPENDIX D-1

GRAVIMETRIC SAMPLE ANALYTICAL DATA

SAMPLE NO.: PV 3

SAMPLE DATE: 03/22/88

CORE HOLE: AC-1

LOCATION: BACKGROUND, right side: $5 \mathrm{ft}$ from floor, $20 \mathrm{ft}$ from face

PRE-WEIGHT (gm): 0.019838

POST-WEIGHT (gm): 0.019956

WEIGHT GAIN (gm): $0.000118(\mu \mathrm{g}) 118$

INDICATED FLOW (liters/m): 2.47

CORRECTED FLOW (liters/m): 2.393

RUN TIME (m): 992

AIR VOLUME (liters): $2373.9\left(\mathrm{~m}^{3}\right) 2.3739$ WEIGHT PER VOL (gm/liters): 0.00000005 WEIGHT PER VOL $\left(\mu \mathrm{g} / \mathrm{m}^{3}\right): 49.707\left(\mathrm{mg} / \mathrm{m}^{3}\right)$

SAMPLE NO.: PV 5

SAMPLE DATE: $03 / 24 / 88$

CORE HOLE: AC-1

LOCATION: On right wall, approximately $16 \mathrm{ft}$ from drill

PRE-WEIGHT (gm): 0.02263

POST-WEIGHT (gm): 0.023019

WEIGHT GAIN (gm): $0.000389(\mu \mathrm{g}) 389$

INDICATED FLOW (liters/m): 1.993

CORRECTED FLOW (liters/ni): 1.922

RUN TIME (m): 65

AIR VOLUME (liters): $124.93\left(\mathrm{~m}^{3}\right) 0.1249$

WEIGHT PER VOL (gm/liters): 0.00000311

WEIGHT PER VOL $\left(\mu \mathrm{g} / \mathrm{m}^{3}\right): 3114.5\left(\mathrm{mg} / \mathrm{m}^{3}\right)$
SAMPLE NO:: PV 6

SAMPLE DATE: 03/30/88

CORE HOLE: AC-1

LOCATION: Right wall, approximately $16 \mathrm{ft}$ from face, set for work shift

PRE-WEIGHT (gm): 0.021936

POST-WEIGHT (gm): 0.022628

WEIGHT GAIN (gm): $0.000692(\mu \mathrm{g}) 692$

INDICATED FLOW (liters/m): 1.954

CORRECTED FLOW (liters/m): 1.883

RUN TIME (m): 338

AIR VOLUME (liters): $636.45\left(\mathrm{~m}^{3}\right) 0.6365$

WEIGHT PER VOL (gm/liters): 0.00000109

WEIGHT PER VOL $\left(\mu \mathrm{g} / \mathrm{m}^{3}\right): 1087.2\left(\mathrm{mg} / \mathrm{m}^{3}\right)$

SAMPLE NO.: PV 9

SAMPLE DATE: 03/30/88

CORE HOLE: AC-1

LOCATION: Area sample on drill (left ovemight)

PRE-WEIGHT (gm): 0.019402

POST-WEIGHT (gm): 0.021054

WEIGHT GAIN (gm): $0.001652(\mu \mathrm{g}) 1652$

INDICATED FLOW (liters/m): 1.988

CORRECTED FLOW (liters/m): 1.917

RUN TIME (m): 900

AIR VOLUME (liters): $1725.3\left(\mathrm{~m}^{3}\right) 1.7253$ WEIGHT PER VOL (gm/liters): 0.00000096 WEIGHT PER VOL $\left(\mu \mathrm{g} / \mathrm{m}^{3}\right): 957.51\left(\mathrm{mg} / \mathrm{m}^{3}\right)$ 
SAMPLE NO.: PV 15

SAMPLE DATE: 03/30/88

CORE HOLE: AC-1

LOCATION: Begin/Extens. Drift, inside curve, right side

PRE-WEIGHT (gm): 0.02005

POST-WEIGHT (gm): 0.020178

WEIGHT GAIN (gm): $0.000128(\mu \mathrm{g}) 128$

INDICATED FLOW (liters/m): 2.34

CORRECTED FLOW (liters/m): 2.265

RUN TIME (m): 206.1

AIR VOLUME (liters): $466.82\left(\mathrm{~m}^{3}\right) 0.4668$

WEIGHT PER VOL (gm/liters): 0.00000027

WEIGHT PER VOL $\left(\mu \mathrm{g} / \mathrm{m}^{3}\right): 274.21\left(\mathrm{mg} / \mathrm{m}^{3}\right)$

SAMPLE NO.: PV 17

SAMPLE DATE: $04 / 13 / 88$

CORE HOLE: AC-2

LOCATION: BACKGROUND, rock bolt left of collar (spider)

PRE-WEIGHT (gm): 0.019685

POST-WEIGHT (gm): 0.019751

WEIGHT GAIN (gm): $0.000066(\mu \mathrm{g}) 66$

INDICATED FLOW (liters/m): 1.787

CORRECTED FLOW (liters/m): 1.718

RUN TIME (m): 720

AIR VOLUME (liters): $1237\left(\mathrm{~m}^{3}\right) 1.237$

WEIGHT PER VOL (gm/iters): 0.00000005

WEIGHT PER VOL $\left(\mu \mathrm{g} / \mathrm{m}^{3}\right): 53.355\left(\mathrm{mg} / \mathrm{m}^{3}\right)$
SAMPLE NO.: PV 22

SAMPLE DATE: 04/20/88

CORE HOLE: AC-2

LOCATION: Rock bolt between DCT and drill collar (spider)

PRE-WEIGHT (gm): 0.019912

POST-WEIGHT (gm): 0.01997

WEIGHT GAIN (gm): $0.000058(\mu \mathrm{g}) 58$

INDICATED FLOW (liters/m): 1.784

CORRECTED FLOW (liters/m): 1.715

RUN TIME (m): 211.2

AIR VOLUME (iiters): $362.21\left(\mathrm{~m}^{3}\right) 0.3622$

WEIGHT PER VOL (gm/iters): 0.00000016

WEIGHT PER VOL $\left(\mu \mathrm{g} / \mathrm{m}^{3}\right): 160.13\left(\mathrm{mg} / \mathrm{m}^{3}\right)$

SAMPLE NO.: PV 31

SAMPLE DATE: 04/14/88

CORE HOLE: AC-2

LOCATION: Left wall by drill collar (spider)

PRE-WEIGHT (gm): 0.019902

POST-WEIGHT (gm): 0.020242

WEIGHT GAIN (gm): $0.00034(\mu \mathrm{g}) 340$

INDICATED FLOW (liters/m): 1.967

CORRECTED FLOW (liters/m): 1.896

RUN TIME (m): 372

AIR VOLUME (liters): $705.31\left(\mathrm{~m}^{3}\right) 0.7053$ WEIGHT PER VOL (gm/liters): 0.00000048 WEIGHT PER VOL $\left(\mu \mathrm{g} / \mathrm{m}^{3}\right): 482.06\left(\mathrm{mg} / \mathrm{m}^{3}\right)$ 
SAMPLE NO.: PV 36

SAMPLE DATE: 04/20/88

CORE HOLE: AC-2

LOCATION: Hanging on wire (middle of personnel area)

PRE-WEIGHT (gm): 0.022456

POST-WEIGHT (gm): 0.022577

WEIGHT GAIN (gm): $0.000121(\mu \mathrm{g}) 121$

INDICATED FLOW (liters/m): 2.227

CORRECTED FLOW (liters/m): 2.153

RUN TIME (m): 218

AIR VOLUME (liters): $469.35\left(\mathrm{~m}^{3}\right) 0.4694$ WEIGHT PER VOL (gm/liters): 0.00000026 WEIGHT PER VOL $\left(\mu \mathrm{g} / \mathrm{m}^{3}\right): 257.78\left(\mathrm{mg} / \mathrm{m}^{3}\right)$

SAMPLE NO.: PV 47

SAMPLE DATE: 04/14/88

CORE HOLE: AC-2

LOCATION: Hanging behind DCT

PRE-WEIGHT (gm): 0.023795

POST-WEIGHT (gm): 0.024137

WEIGHT GAIN (gm): $0.000342(\mu \mathrm{g}) 342$

INDICATED FLOW (liters/m): 1.928

CORRECTED FLOW (liters/m): 1.858

RUN TIME (m): 368

AIR VOLUME (liters): $683.74\left(\mathrm{~m}^{3}\right) 0.6837$

WEIGHT PER VOL (gm/iters): 0.0000005

WEIGHT PER VOL $\left(\mu \mathrm{g} / \mathrm{m}^{3}\right): 500.22\left(\mathrm{mg} / \mathrm{m}^{3}\right)$
SAMPLE NO.: PV 13B

SAMPLE DATE: 04/07/88

CORE HOLE: AC-1

LOCATION: BLANK - PV samples

PRE-WEIGHT (gm): 0.02013

POST-WEIGHT (gm): 0.020108

WEIGHT GAIN $(\mathrm{gm}):-0.00002(\mu \mathrm{g})-20$

INDICATED FLOW (liters/m): 0 CORRECTED FLOW (liters/m): 0 RUN TIME (m): 0

AIR VOLUME (liters): $0\left(\mathrm{~m}^{3}\right) 0$ WEIGHT PER VOL (gm/iters): 0 WEIGHT PER VOL $\left(\mu \mathrm{g} / \mathrm{m}^{3}\right): 0\left(\mathrm{mg} / \mathrm{m}^{3}\right)$ 


\section{APPENDIX D-2}

SILICA SAMPLE ANALYTICAL DATA

SAMPLE ID: FW 391

SAMPLE DATE: $04 / 19 / 88$

CORE HOLE: AC-2

LOCATION: Personal Sample [Personal Sample (PS)-driller]

PUMP FLOW [corrected] (liters/m): 1.679

RUN TIME (min): 270.1

AIR VOLUME (liters): 453.5

TOTAL WT. GAIN (mg): 0.12

QUARTZ (mg): ND

CRISTOBALITE (mg): ND

TRIDYMITE (mg): ND

SAMPLE ID: FW 392

SAMPLE DATE: 04/20/88

CORE HOLE: AC-2

LOCATION: Personal Sample (PS)-(WEARER

was Out of Area approximately

25 min AM + approximately 45 min PM)

PUMP FLOW [corrected] (liters/m): 1.693

RUN TIME (min): 257

AIR VOLUME (liters): 435.1

TOTAL WT. GAIN (mg): 0.10

QUARTZ (mg): (0.02) LOD

CRISTOBALITE (mg): ND

TRIDYMITE (mg): ND

SAMPLE ID: FW 393

SAMPLE DATE: 04/20/88

CORE HOLE: $A C-2$

LOCATION: Laser Drift, rock bolt $6 \mathrm{ft}$ from drill collar

PUMP FLOW [corrected] (liters/m): 1.66

RUN TIME (min): 256.6

AIR VOLUME (liters): 426

TOTAL WT. GAIN (mg): 0.10

QUARTZ (mg): ND

CRISTOBALITE (mg): ND

TRIDYMITE (mg): ND
SAMPLE ID: FW 394

SAMPLE DATE: 04/19/88

CORE HOLE: AC-2

LOCATION: Wire hanger $6 \mathrm{ft}$ high (in personnel area)

PUMP FLOW [corrected] (liters/m): 1.7

RUN TIME (min): 270

AIR VOLUME (liters): 459

TOTAL WT. GAIN (mg): 0.15

QUARTZ (mg): ND

CRISTOBALITE (mg): ND

TRIDYMITE (mg): ND

SAMPLE ID: FW 395

SAMPLE DATE: 04/20/88

CORE HOLE: AC-2

LOCATION: Laser Drift, on front of DCT

PUMP FLOW [corrected] (liters/m): 1.662

RUN TIME (min): 256.1

AIR VOLUME (liters): 425.6

TOTAL WT. GAIN (mg): 0.13

QUARTZ (mg): ND

CRISTOBALITE (mg): ND

TRIDYMITE (mg): ND

SAMPLE ID: FW 396

SAMPLE DATE: 04/20/88

CORE HOLE: AC-2

LOCATION: Laser Drift incline just below core boxes

PUMP FLOW [corrected] (liters/m): 1.656

RUN TIME (min): 192

AIR VOLUME (liters): 318

TOTAL WT. GAIN (mg): 0.04

QUARTZ (mg): ND

CRISTOBALITE (mg): ND

TRIDYMITE (mg): ND 
SAMPLE ID: FW 398

SAMPLE DATE: 04/20/88

CORE HOLE: AC-2

LOCATION: Personal Sample (PS)-driller

PUMP FLOW [corrected] (liters/m): 1.704

RUN TIME (min): 183

AIR VOLUME (liters): 311.8

TOTAL WT. GAIN (mg): 0.10

QUARTZ (mg): ND

CRISTOBALITE (mg): ND

TRIDYMITE (mg): ND

SAMPLE ID: FW 399

SAMPLE DATE: 04/20/88

CORE HOLE: AC-2

LOCATION: Wire hanger $6 \mathrm{ft}$ high (in personnel area)

PUMP FLOW [corrected] (liters/m): 1.718

RUN TIME (min): 263.9

AIR VOLUME (liters): 253.4

TOTAL WT. GAIN (mg): 0.11

QUARTZ (mg): ND

CRISTOBALITE (mg): ND

TRIDYMITE (mg): ND

SAMPLE ID: FW 400-B

SAMPLE DATE: 04/21/88

CORE HOLE: AC-2

LOCATION: BLIND BLANK - FW samples

PUMP FLOW [corrected] (liters/m): 0

RUN TIME (min): 0

AIR VOLUME (liters): $\mathbf{4 2 0 . 1}$

TOTAL WT. GAIN (mg): 0.03

QUARTZ (mg): (0.02) LOD

CRISTOBALITE (mg): ND

TRIDYMITE (mg): ND
SAMPLE ID: FW 407-B

SAMPLE DATE: 04/05/88

CORE HOLE: AC-1

LOCATION: BLIND BLANK - FW samples

PUMP FLOW [corrected] (liters/m): 1.753

RUN TIME (min): 50

AIR VOLUME (liters): 87.7

TOTAL WT. GAN (mg): 1.03

QUARTZ (mg): ND

CRISTOBALITE (mg): ND

TRIDYMITE (mg): ND

SAMPLE ID: FW 610

SAMPLE DATE: 03/22/88

CORE HOLE: AC-1

LOCATION: BACKGROUND - Demo. Drift, on

DCT approximately $4 \mathrm{ft}$ above floor

PUMP FLOW [corrected] (liters/m): 1.678

RUN TIME (min): 100

AIR VOLUME (liters): 167.8

TOTAL WT. GAIN (mg): 0.03

QUARTZ(mg): ND

CRISTOBALITE (mg): ND

TRIDYMTTE (mg): ND

SAMPLE ID: FW 611

SAMPLE DATE: 03/22/88

CORE HOLE: AC-I

LOCATION: BACKGROUND - right side, approximately $8 \mathrm{ft}$ face, approximately $4 \mathrm{ft}$ above floor

PUMP FLOW [corrected] (liters/m): 1.705

RUN TIME (min): 998

AIR VOLUME (liters): 1702

TOTAL WT. GAIN (mg): 0.05

QUARTZ (mg): ND

CRISTOBALITE (mg): ND

TRIDYMITE (mg): ND 
SAMPLE ID: FW 612

SAMPLE DATE: 03/23/88

CORE HOLE: AC-1

LOCATION: Personal Sample (PS)-helper, during DCT \& collar leak

PUMP FLOW [corrected] (liters/m): 1.684

RUN TIME (min): 102.1

AIR VOLUME (liters): 171.8

TOTAL WT. GAIN (mg): 0.20

QUARTZ (mg): (0.02) LOD

CRISTOBALITE (mg): ND

TRIDYMITE (mg): ND

SAMPLE ID: FW 613

SAMPLE DATE: 03/25/88

CORE HOLE: AC-1

LOCATION: Personal Sample (PS)-drilling

consultant

PUMP FLOW [corrected] (liters/m): 1.63

RUN TIME (min): 65.32

AIR VOLUME (liters): 106.3

TOTAL WT. GAIN (mg): 0.29

QUARTZ (mg): (0.02) LOD

CRISTOBALITE (mg): ND

TRIDYMITE (mg): ND

SAMPLE ID: FW 614

SAMPLE DATE: 03/25/88

CORE HOLE: AC-1

LOCATION: Personal Sample (PS)-driller

PUMP FLOW [corrected] (liters/m): 1.656

RUN TIME (min): 73

AIR VOLUME (liters): 120.9

TOTAL WT. GAIN (mg): 0.18

QUARTZ (mg): (0.02)LOD

CRISTOBALITE (mg): ND

TRIDYMITE (mg): ND
SAMPLE ID: FW 615

SAMPLE DATE: $33 / 29 / 88$

CORE HOLE: AC-1

LOCATION: Personal Sample (PS)-driller

PUMP FLOW [corrected] (liters/m): 1.614

RUN TIME (min): 221.1

AIR VOLUME (liters): 356.9

TOTAL WT. GAIN (mg): 0.18

QUARTZ(mg): ND

CRISTOBALITE (mg): ND

TRIDYMITE (mg): ND

SAMPLE ID: FW 616

SAMPLE DATE: 03/23/88

CORE HOLE: AC-1

LOCATION: Personal Sample (PS)-driller

PUMP FLOW [corrected] (liters/m): 1.67

RUN TTME (min): 76

AIR VOLUME (liters): 126.9

TOTAL WT. GAIN (mg): 0.12

QUARTZ (mg): ND

CRISTOBALITE (mg): ND

TRIDYMITE (mg): ND

SAMPLE ID: FW 619-B

SAMPLE DATE: $03 / 24 / 88$

CORE HOLE: AC-1

LOCATION: BLIND BLANK - FW samples

PUMP FLOW [corrected] (liters/n): 1.71

RUN TIME (min): 150

AIR VOLUME (liters): 256.5

TOTAL WT. GAIN (mg): -0.02

QUARTZ(mg): ND

CRISTOBALITE (mg): ND

TRIDYMITE (mg): ND 
SAMPLE ID: FW 620

SAMPLE DATE: 03/30/88

CORE HOLE: AC-1

LOCATION: Personal Sample (PS)-driller

PUMP FLOW [corrected] (liters/m): 1.646

RUN TIME (min): 167.1

AIR VOLUME (liters): 275.1

TOTAL WT. GAIN (mg): 0.14

QUARTZ (mg): ND

CRISTOBALITE (mg): ND

TRIDYMITE (mg): ND

SAMPLE ID: FW 621

SAMPLE DATE: 03/29/88

CORE HOLE: AC-1

LOCATION: Personal Sample (PS)-investigator

PUMP FLOW [corrected] (liters/m): 1.622

RUN TIME (min): 122

AIR VOLUME (liters): 197.9

TOTAL WT. GAIN (mg): 0.11

QUARTZ (mg): ND

CRISTOBALITE (mg): ND

TRIDYMITE (mg): ND

SAMPLE ID: FW 622

SAMPLE DATE: 03/29/88

CORE HOLE: AC-1

LOCATION: Personal Sample (PS)-drilling

consultant

PUMP FLOW [corrected] (liters/m): 1.646

RUN TIME (min): 131

AIR VOLUME (liters): 215.6

TOTAL WT. GAIN (mg): 0.14

QUARTZ(mg): ND

CRISTOBALITE (mg): ND

TRIDYMITE (mg): ND
SAMPLE ID: FW 623

SAMPLE DATE: $03 / 30 / 88$

CORE HOLE: AC-1

LOCATION: Personal Sample (PS)-drilling consultant

PUMP FLOW [corrected] (liters/m): 1.698

RUN TIME (min): 237

AIR VOLUME (liters): 402.4

TOTAL WT. GAIN (mg): 0.13

QUARTZ (mg): ND

CRISTOBALITE (mg): ND

TRIDYMITE (mg): ND

SAMPLE ID: FW 624

SAMPLE DATE: 03/29/88

CORE HOLE: AC-1

LOCATION: Personal Sample (PS)-helper (no

weight gain)

PUMP FLOW [corrected] (liters/m): 1.685

RUN TIME (min): 132.9

AIR VOLUME (liters): 223.9

TOTAL WT. GAIN (mg): -0.01

QUARTZ (mg): ND

CRISTOBALITE (mg): ND

TRIDYMTTE (mg): ND

SAMPLE ID: FW 625

SAMPLE DATE: 03/29/88

CORE HOLE: $A C-1$

LOCATION: Demo. Drift face between DCT \&

collar

PUMP FLOW [corrected] (liters/m): 1.646

RUN TIME (min): 124.3

AIR VOLUME (liters): 204.6

TOTAL WT. GAIN (mg): 0.52

QUARTZ (mg): 0.04

CRISTOBALITE (mg): ND

TRIDYMITE (mg): ND 
SAMPLE ID: FW 626

SAMPLE DATE: 03/30/88

CORE HOLE: $A C-1$

LOCATION: Demo. Drift left wall above impactor

PUMP FLOW [corrected] (liters/m): 1.684

RUN TIME (min): 340.9

AIR VOLUME (liters): 574.1

TOTAL WT. GAIN (mg) 0.38

QUARTZ (mg): ND

CRISTOBALITE (mg): ND

TRIDYMITE (mg): ND

SAMPLE ID: FW 627

SAMPLE DATE: 03/30/88

CORE HOLE: AC-1

LOCATION: Demo. Drift right wall above

impactor

PUMP FLOW [corrected] (liters/m): 1.679

RUN TIME (min): 338.8

AIR VOLUME (liters): 568.9

TOTAL WT. GAIN (mg): 0.11

QUARTZ (mg): ND

CRISTOBALITE (mg): ND

TRIDYMITE (mg): ND

SAMPLE ID: FW 630

SAMPLE DATE: $04 / 13 / 88$

CORE HOLE: AC-2

LOCATION: BACKGROUND - Laser Drift - On

drill hoist chain

PUMP FLOW [corrected] (liters/m): 1.708

RUN TIME (min): 720

AIR VOLUME (liters): I230

TOTAL WT. GAIN (mg): 0.03

QUARTZ (mg): ND

CRISTOBALITE (mg): ND

TRIDYMITE (mg): ND
SAMPLE ID: FW 631

SAMPLE DATE: $04 / 14 / 88$

CORE HOLE: AC-2

LOCATION: Laser Drift, right wall in line w/DCT

PUMP FLOW [corrected] (liters/m): 1.685

RUN TIME (min): 349.2

AIR VOLUME (liters): $\mathbf{5 8 8 . 4}$

TOTAL WT. GAIN (mg): 0.13

QUARTZ (mg): ND

CRISTOBALITE (mg): ND

TRIDYMITE (mg): ND

SAMPLE ID: FW 632

SAMPLE DATE: 04/14/88

CORE HOLE: AC-2

LOCATION: Personal Sample (PS)-driller

PUMP FLOW [corrected] (liters/m): 1.661

RUN TIME (min): 160

AIR VOLUME (liters): 365.8

TOTAL WT. GAIN (mg): 0.15

QUARTZ (mg): ND

CRISTOBALITE (mg): ND

TRIDYMITE (mg): ND

SAMPLE ID: FW 633

SAMPLE DATE: $04 / 14 / 88$

CORE HOLE: AC-2

LOCATION: $15 \mathrm{ft}$ drill wall, center DCT \& wall, approximately $4 \mathrm{ft}$ above floor

PUMP FLOW [corrected] (liters/m): 1.612

RUN TIME (min): 265

AIR VOLUME (liters): 427.2

TOTAL WT. GAIN (mg): 0.10

QUARTZ (mg): ND

CRISTOBALITE (mg): ND

TRIDYMITE (mg): ND 
SAMPLE ID: FW 634-B

SAMPLE DATE: $04 / 19 / 88$

CORE HOLE: AC-2

LOCATION: BLIND BLANK - FW samples

PUMP FLOW [corrected] (liters/m): 0

RUN TIME (min): 0

AIR VOLUME (iters): 324.2

TOTAL WT. GAIN (mg): 0

QUARTZ(mg): ND

CRISTOBALITE (mg): ND

TRIDYMITE (mg): ND

SAMPLE ID: FW 641

SAMPLE DATE: 04/20/88

CORE HOLE: AC-2

LOCATION: Personal Sample (PS)-helper

PUMP FLOW [corrected] (liters/m): 1.66

RUN TIME (min): 379.7

AIR VOLUME (liters): 630.3

TOTAL WT. GAIN (mg): 0.11

QUARTZ (mg): ND

CRISTOBALITE (mg): ND

TRIDYMITE (mg): ND

SAMPLE ID.: AC-1/R7 \#3

SAMPLE DATE: 03/29/88

CORE HOLE: AC-1

LOCATION: Bulk sample \#3 from DCT Bag,

Run 7

QUARTZ (\%): 6.8

CRISTOBALITE (\%): ND

TRIDYMITE (\%): ND

SAMPLE ID.: AC-2/R8-12 \#3

SAMPLE DATE: 04/13/88

CORE HOLE: AC-2

LOCATION: Bulk sample *3 from DCT Bag,

Runs 8 - 12

QUARTZ (\%): 11.0

CRISTOBALITE (\%): ND

TRIDYMITE (\%): ND 
APPENDIX D-3

FIBER SAMPLE ANALYTICAL DATA

SAMPLE NO.: CE 52

SAMPLE DATE: $03 / 22 / 88$

CORE HOLE: AC-1

LOCATION: BACKGROUND sample. Positioned on drill.

SAMPLING VOL (liters): 1278

FIBERS COUNTED/100 Optical Fields (fibers): 2 FIBER CONC. $\left(\mathrm{f} / \mathrm{cm}^{3}\right)$ : NA

ANAL YTICAL COMMENTS: Uncountable.

SAMPLE NO.: CE 53

SAMPLE DATE: $03 / 23 / 88$

CORE HOLE: AC-1

LOCATION: Right wall, approximately $3 \mathrm{ft}$ behind impactor, approximately $6 \mathrm{ft}$ from floor.

SAMPLING VOL (liters): 129.1

FIBERS COUNTED/100 Optical Fields (fibers): 0 FIBER CONC. $\left(\mathrm{f} / \mathrm{cm}^{3}\right)$ : NA

ANALYTICAL COMMENTS: Uncountable.

SAMPLE NO.: CE 54

SAMPLE DATE: $03 / 23 / 88$

CORE HOLE: AC-1

LOCATION: Left wall, approximately $6.5 \mathrm{ft}$ from face.

SAMPLING VOL (liters): 122.7

FIBERS COUNTED/100 Optical Fields (fibers): 0 FIBER CONC. $\left(\mathrm{f} / \mathrm{cm}^{3}\right)$ : NA

ANALYTICAL COMMENTS: Uncountable.

SAMPLE NO.: CE 55

SAMPLE DATE: 03/23/88

CORE HOLE: AC-I

LOCATION: Hanging above drill rig.

SAMPLING VOL (liters): 106.3

FIBERS COUNTED/100 Optical Fields (fibers): 0 FIBER CONC. $\left(\mathrm{f} / \mathrm{cm}^{3}\right)$ : NA

ANALYTICAL COMMENTS: Uncountable.
SAMPLE NO.: CE 75B

SAMPLE DATE: 03/24/88

CORE HOLE: $A C-1$

LOCATION: BLIND BLANK - CE samples.

SAMPLING VOL (liters): 0

FIBERS COUNTED/100 Optical Fields (fibers): 0 FIBER CONC $\left(\mathrm{f} / \mathrm{cm}^{3}\right)$ : NA ANALYTICAL COMMENTS: Filter Blank.

SAMPLE NO.: CE 56

SAMPLE DATE: 03/25/88

CORE HOLE: AC-1

LOCATION: PERSONAL SAMPLE.

SAMPLING VOL (liters): 121.7

FIBERS COUNTED/100 Optical Fields (fibers): 0 FIBER CONC. $\left(\mathrm{f} / \mathrm{cm}^{3}\right)$ : NA

ANALYTICAL COMMENTS: Uncountable.

SAMPLE NO.: CE 57

SAMPLE DATE: 03/25/88

CORE HOLE: AC-1

LOCATION: PERSONAL SAMPLE.

SAMPLING VOL (liters): 147.4

FIBERS COUNTED/100 Optical Fields (fibers): 4 FIBER CONC. $\left(\mathrm{f} / \mathrm{cm}^{3}\right)$ : $<0.05$

ANALYTICAL COMMENTS: Deposit Nonfibrous.

SAMPLE NO.: CE 50B

SAMPLE DATE: 03/28/88

CORE HOLE: $A C-1$

LOCATION: BLIND BLANK - CE samples.

SAMPLING VOL (liters): 0

FIBERS COUNTED/100 Optical Fields (fibers): 2 FIBER CONC. $\left(\mathrm{f} / \mathrm{cm}^{3}\right)$ : NA

ANALYTICAL COMMENTS: Filter Blank. 
SAMPLE NO.: CE 59

SAMPLE DATE: 03/30/88

CORE HOLE: AC-1

LOCATION: Left wall, even with drill.

SAMPLING VOL (liters): 109.7

FIBERS COUNTED/100 Optical Fields (fibers): 3 FIBER CONC. $\left(\mathrm{f} / \mathrm{cm}^{3}\right):<0.05$

ANAL YTICAL COMMENTS: Deposit Nonfibrous.

SAMPLE NO.: CE 60

SAMPLE DATE: 03/30/88

CORE HOLE: $A C-1$

LOCATION: Behind drill, to the left.

SAMPLING VOL (liters): 55

FIBERS COUNTED/100 Optical Fields (fibers): 1 FIBER CONC. $\left(\mathrm{f} / \mathrm{cm}^{3}\right):<0.05$

ANAL YTICAL COMMENTS: Very Few Particles.

SAMPLE NO.: CE 61

SAMPLE DATE: $03 / 30 / 88$

CORE HOLE: AC-1

LOCATION: Right wall near DCT.

SAMPLING VOL (liters): 27.1

FIBERS COUNTED/100 Optical Fields (fibers): 0 FIBER CONC. $\left(\mathrm{f} / \mathrm{cm}^{3}\right)$ : NA

ANALYTICAL COMMENTS: Back-up Separator Paper in Place.

SAMPLE NO.: CE 62

SAMPLE DATE: $03 / 30 / 88$

CORE HOLE: AC-1

LOCATION: Between wall and drill.

SAMPLING VOL (liters): 57.3

FIBERS COUNTED/100 Optical Fields (fibers): 7 FIBER CONC. $\left(\mathrm{f} / \mathrm{cm}^{3}\right): 0.06$

ANALYTICAL COMMENTS: Few Fibers - Deposit Nonfibrous.
SAMPLE NO: CE 64

SAMPLE DATE: 03/30/88

CORE HOLE: AC-1

LOCATION: On face in Demonstration Drift.

SAMPLING VOL (liters): 62.3

FIBERS COUNTED/100 Optical Fields (fibers): 6 FIBER CONC. $\left(\mathrm{f} / \mathrm{cm}^{3}\right): 0.05$

ANAL YTICAL COMMENTS: Few Fibers - Deposit Nonfibrous.

SAMPLE NO.: CE 65

SAMPLE DATE: 03/30/88

CORE HOLE: AC-1

LOCATION: Between wall and drill rig.

SAMPLING VOL (liters): 43.9

FIBERS COUNTED/100 Optical Fields (fibers): 4 FIBER CONC. $\left(\mathrm{f} / \mathrm{cm}^{3}\right):<0.05$

ANAL YTICAL COMMENTS: Few fibers - Deposit Nonfibrous.

SAMPLE NO.: CE 66

SAMPLE DATE: 03/30/88

CORE HOLE: $A C-1$

LOCATION: Right wall near DCT.

SAMPLING VOL (liters): 54.2

FIBERS COUNTED/100 Optical Fields (fibers): 4 FIBER CONC. $\left(\mathrm{f} / \mathrm{cm}^{3}\right):<0.05$

ANALYTICAL COMMENTS: Few fibers - Deposit Nonfibrous.

SAMPLE NO.: CE 67

SAMPLE DATE: 03/30/88

CORE HOLE: AC-1

LOCATION: At face in Demonstration Drift.

SAMPLING VOL (liters): 31.1

FIBERS COUNTED/100 Optical Fields (fibers): 4 FIBER CONC. $\left(\mathrm{f} / \mathrm{cm}^{3}\right): 0.06$

ANAL YTICAL COMMENTS: Few fibers - Deposit Nonfibrous. 
SAMPLE NO.: CE 69

SAMPLE DATE: 03/30/88

CORE HOLE: AC-1

LOCATION: Right wall near impactor at CE sample site.

SAMPLING VOL (liters): 30.2

FIBERS COUNTED/100 Optical Fields (fibers): 3 FIBER CONC. $\left(\mathrm{f} / \mathrm{cm}^{3}\right): 0.05$

ANAL YTICAL COMMENTS: Vehicle Exhaust.

SAMPLE NO.: CE 74

SAMPLE DATE: 03/30/88

CORE HOLE: AC-1

LOCATION: At drill rig between drill and wall.

SAMPLING VOL (liters): 86

FIBERS COUNTED/100 Optical Fields (fibers): 3 FIBER CONC. $\left(\mathrm{f} / \mathrm{cm}^{3}\right):<0.05$

ANAL YTICAL COMMENTS: Vehicle Exhaust.

SAMPLE NO.: CE 58

SAMPLE DATE: 03/31/88

CORE HOLE: AC-1

LOCATION: At drill to left of operator.

SAMPLING VOL (liters): 29.9

FIBERS COUNTED/100 Optical Fields (fibers): 2 FIBER CONC. $\left(\mathrm{f} / \mathrm{cm}^{3}\right):<0.05$

ANALYTICAL COMMENTS: Deposit Nonfibrous.

SAMPLE NO.: CE 68

SAMPLE DATE: $03 / 31 / 88$

CORE HOLE: AC-1

LOCATION: Left wall just behind drill plane.

SAMPLING VOL (liters): 31.1

FIBERS COUNTED/100 Optical Fields (fibers): 4 FIBER CONC. $\left(\mathrm{f} / \mathrm{cm}^{3}\right): 0.06$

ANAL YTICAL COMMENTS: Few fibers - Deposit Nonfibrous.
SAMPLE NO.: CE 45B

SAMPLE DATE: $04 / 04 / 88$

CORE HOLE: AC-1

LOCATION: BLIND BLANK - CE samples.

SAMPLING VOL (liters): 0

FIBERS COUNTED/100 Optical Fields (fibers): 1 FIBER CONC. $\left(\mathrm{f} / \mathrm{cm}^{3}\right):$ NA ANAL YTICAL COMMENTS: Filter Blank.

SAMPLE NO.: CE 49B

SAMPLE DATE: $04 / 04 / 88$

CORE HOLE: AC-1

LOCATION: BLIND BLANK - CE samples.

SAMPLING VOL (liters): 0

FIBERS COUNTED/100 Optical Fields (fibers): 2

FIBER CONC. $\left(\mathrm{f} / \mathrm{cm}^{3}\right):$ NIA

ANALYTICAL COMMENTS: Filter Blank.

SAMPLE NO.: CE 71

SAMPLE DATE: $04 / 13 / 88$

CORE HOLE: AC-2

LOCATION: BACKGROUND, on Rock bolt, left of drill collar.

SAMPLING VOL (liters): 1436.4

FIBERS COUNTED/100 Optical Fields (fibers): 1 FIBER CONC. $\left(\mathrm{f} / \mathrm{cm}^{3}\right):<0.05$

ANALYTICAL COMMENTS: Deposit Nonfibrous.

SAMPLE NO.: CE 72

SAMPLE DATE: 04/14/88

CORE HOLE: AC-2

LOCATION: On wall approximately $5 \mathrm{ft}$ to right of drill collar.

SAMPLING VOL (liters): 58.5

FIBERS COUNTED/100 Optical Fields (fibers): 27 FIBER CONC. $\left(i / \mathrm{cm}^{3}\right): 0.22$

ANALYTICAL COMMENTS: Some Fibers Unusual Morphology. 
SAMPLE NO.: CE 1

SAMPLE DATE: 04/14/88

CORE HOLE: AC-2

LOCATION: Hanger between drill and table (in personal area).

SAMPLING VOL (liters): 127.8

FIBERS COUNTED/100 Optical Fieids (fibers): 2 FIBER CONC. $\left(\mathrm{f} / \mathrm{cm}^{3}\right):<0.05$

ANAL YTICAL COMMENTS: Deposit Nonfibrous.

SAMPLE NO.: CE 2

SAMPLE DATE: 04/14/88

CORE HOLE: AC-2

LOCATION: On wall between DCT and drill collar.

SAMPLING VOL (liters): 127.5

FIBERS COUNTED/100 Optical Fields (fibers): 3 FIBER CONC. $\left(\mathrm{f} / \mathrm{cm}^{3}\right):<0.05$

ANAL YTICAL COMMENTS: Deposit Nonfibrous.

SAMPLE NO.: CE 4

SAMPLE DATE: 04/14/88

CORE HOLE: AC-2

LOCATION: On wall, approximately $5 \mathrm{ft}$ right of

drill collar.

SAMPLING VOL (liters): 37

FIBERS COUNTED/100 Optical Fields (fibers): 2 FIBER CONC. $\left(\mathrm{f} / \mathrm{cm}^{3}\right):<0.05$

ANAL YTICAL COMMENTS: Deposit Nonfibrous.

SAMPLE NO: CE 6

SAMPLE DATE: 04/14/88

CORE HOLE: AC-2

LOCATION: On wall between DCT and drill collar.

SAMPLING VOL (liters): 127.5

FIBERS COUNTED/100 Optical Fields (fibers): 13 FIBER CONC. $\left(\mathrm{f} / \mathrm{cm}^{3}\right): 0.05$

ANAL YTICAL COMMENTS: Some Fibers -

Deposit Light.
SAMPLE NO.: CE 73B

SAMPLE DATE: $04 / 15 / 88$

CORE HOLE: AC-2

LOCATION: BLIND BLANK - CE samples.

SAMPLING VOL (liters): 0

FIBERS COUNTED/100 Optical Fields (fibers): 2 FIBER CONC. $\left(\mathrm{f} / \mathrm{cm}^{3}\right)$ : NA

ANAL YTICAL COMMENTS: Filter Blank.

SAMPLE NO.: CE 3

SAMPLE DATE: 04/20/88

CORE HOLE: AC-2

LOCATION: On water box in middle of drift.

SAMPLING VOL (liters): 121.4

FIBERS COUNTED/100 Optical Fields (fibers): 3 FIBER CONC. $\left(f / \mathrm{cm}^{3}\right):<0.05$

ANAL YTICAL COMMENTS: Vehicle Exhaust.

SAMPLE NO.: CE 7

SAMPLE DATE: $04 / 20 / 88$

CORE HOLE: AC-2

LOCATION: On DCT.

SAMPLING VOL (liters): 185.5

FIBERS COUNTED/100 Optical Fields (fibers): 2 FIBER CONC. $\left(\mathrm{f} / \mathrm{cm}^{3}\right):<0.05$

ANAL YTICAL COMMENTS: Deposit Nonfibrous.

SAMPLE NO.: CE 8

SAMPLE DATE: $04 / 20 / 88$

CORE HOLE: AC-2

LOCATION: On DCT.

SAMPLING VOL (liters): 61.8

FIBERS COUNTED/100 Optical Fields (fibers): 1 FIBER CONC. $\left(\mathrm{f} / \mathrm{cm}^{3}\right):<0.05$

ANAL YTICAL COMMENTS: Deposit Nonfibrous. 
SAMPLE NO.: CE 12

SAMPLE DATE: 04/20/88

CORE HOLE: AC-2

LOCATION: On wall by impactor, between drill and table.

SAMPLING VOL (liters): 290.8

FIBERS COUNTED/100 Optical Fields (fibers): 2 FIBER CONC. $\left(\mathrm{f} / \mathrm{cm}^{3}\right):<0.05$

ANALYTICAL COMMENTS: Deposit Nonfibrous.

SAMPLE NO.: CE 13

SAMPLE DATE: 04/20/88

CORE HOLE: AC-2

LOCATION: On DCT.

SAMPLING VOL (liters): 123.7

FIBERS COUNTED/100 Optical Fields (fibers): 2 FIBER CONC. $\left(\mathrm{f} / \mathrm{cm}^{3}\right):<0.05$

ANALYTICAL COMMENTS: Deposit Nonfibrous, Vehicle Exhaust.

SAMPLE NO:: CE 17

SAMPLE DATE: 04/20/88

CORE HOLE: AC-2

LOCATION: On water box in middle of drift.

SAMPLING VOL (liters): 121.7

FIBERS COUNTED/100 Optical Fields (fibers): 2 FIBER CONC. $\left(\mathrm{f} / \mathrm{cm}^{3}\right):<0.05$

ANALYTICAL COMMENTS: Vehicle Exhaust.

SAMPLE NO.: CE 19

SAMPLE DATE: 04/20/88

CORE HOLE: AC-2

LOCATION: On wall behind DCT.

SAMPLING VOL (liters): 60.7

FIBERS COUNTED/100 Optical Fields (fibers): 1

FIBER CONC. $\left(\mathrm{f} / \mathrm{cm}^{3}\right):<0.05$

ANAL YTICAL COMMENTS: Deposit Very Light.
SAMPLE NO.: CE 20B

SAMPLE DATE: $04 / 26 / 88$

CORE HOLE: AC-2

LOCATION: BLIND BLANK - CE samples.

SAMPLING VOL (liters): 0

FIBERS COUNTED/00 Optical Fields (fibers): 1 FIBER CONC. $\left(\mathrm{f} / \mathrm{cm}^{3}\right)$ : NA ANALYTICAL COMMENTS: Filter Blank. 


\section{APPENDIX D-4}

PIXE SAMPLE ANALYTICAL DATA

SAMPLE NO:: NP4

SAMPLE DATE: 04/20/88

CORE HOLE: AC-2

LOCATION: On DCT
MASS $\mu \mathrm{g} / \mathrm{cm}^{2}: 5.887699$

FILTER AREA-1 $\left(\mathrm{cm}^{2}\right): 4.155$ FILTER AREA-2 $\left(\mathrm{cm}^{2}\right) ; 0.801$ AIR VOLUME-1 $\left(\mathrm{m}^{3}\right): 0.294$ AIR VOLUME-2 $\left(\mathrm{m}^{3}\right): 0.294$

\begin{tabular}{|c|c|c|c|c|c|c|}
\hline ELEMENTS & $\begin{array}{l}\text { ENERGY } \\
\text { (KEV) }\end{array}$ & $\begin{array}{l}\text { DETECT. } \\
\text { LIMIT }\end{array}$ & $\begin{array}{l}\text { ELEMENTAL } \\
\text { CONC. }\end{array}$ & $\begin{array}{c}\text { ELEMENTA } \\
\text { MASS } \\
\mu g / \mathrm{cm}^{2}\end{array}$ & $\begin{array}{c}\text { MASS/VOL-1 } \\
\mu \mathrm{g} / \mathrm{m}^{3}\end{array}$ & $\begin{array}{c}\text { MASS } / \text { VL-2 } \\
\mu \mathrm{g} / \mathrm{m}^{3}\end{array}$ \\
\hline ALUMINUM & 1.487 & 0.0061 & 0.019666 & 0.115787 & 1.636378 & 1.496961 \\
\hline SILICON & 1.74 & 0.0038 & 0.063751 & 0.375347 & 5.304649 & 4.852701 \\
\hline PHOSPHORUS & 0 & 0 & 0 & 0 & 0 & 0 \\
\hline SULFUR & 2.308 & 0.0029 & 0.020969 & 0.123459 & 1.744803 & 1.596149 \\
\hline CHLORINE & 2.622 & 0.0025 & 0.00834 & 0.049103 & 0.693956 & 0.634832 \\
\hline POTASSIUM & 3.314 & 0.0018 & 0.008698 & 0.051211 & 0.723747 & 0.662085 \\
\hline CALCIUM & 3.692 & 0.0017 & 0.009648 & 0.056805 & 0.802805 & 0.734408 \\
\hline TITANIUM & 4.511 & 0.0011 & 0.001593 & 0.009379 & 0.13255 & 0.121257 \\
\hline VANADIUM & 0 & 0 & 0 & 0 & 0 & 0 \\
\hline CHROMIUM & 5.415 & 0.0004 & 0.001098 & 0.006465 & 0.091368 & 0.083583 \\
\hline MANGANESE & 5.899 & 0.0003 & 0.000509 & 0.002997 & 0.042356 & 0.038747 \\
\hline IRON & 6.399 & 0.0002 & 0.04169 & 0.245458 & 3.468973 & 3.173421 \\
\hline NICKEL & 0 & $\mathbf{0}$ & 0 & 0 & 0 & 0 \\
\hline COPPER & 8.041 & 0.0001 & 0.000245 & 0.001442 & 0.020379 & 0.018643 \\
\hline ZINC & 8.631 & 0.0001 & 0.001795 & 0.010568 & 0.149354 & 0.136629 \\
\hline BROMINE & 11.924 & 0.0008 & 0.321167 & 1.890935 & 26.72393 & 24.44709 \\
\hline STRONTIUM & 0 & 0 & $\mathbf{0}$ & 0 & $\mathbf{0}$ & 0 \\
\hline MOLYBDENUM & $\mathbf{0}$ & 0 & 0 & $\mathbf{0}$ & 0 & 0 \\
\hline CADMIUM & 0 & 0 & 0 & $\mathbf{0}$ & 0 & 0 \\
\hline ANTIMONY & 0 & 0 & 0 & 0 & 0 & 0 \\
\hline LEAD & 10.552 & 0.0006 & 0.000832 & 0.004899 & 0.069236 & 0.063337 \\
\hline
\end{tabular}


SAMPLE NO.: NP 5

MASS $\mu \mathrm{g} / \mathrm{cm}^{2}: 4.517624$

FILTER AREA-1 $\left(\mathrm{cm}^{2}\right): 4.155$

SAMPLE DATE: 04/19/88

FILTER AREA-2 $\left(\mathrm{cm}^{2}\right): 3.801$

CORE HOLE: AC-2

AIR VOLUME-1 $\left(\mathrm{m}^{3}\right): 0.105$

LOCATION: On DCT front

AIR VOLUME-2 $\left(\mathrm{m}^{3}\right): 0.105$

\begin{tabular}{|c|c|c|c|c|c|c|}
\hline ELEMENTS & $\begin{array}{l}\text { ENERGY } \\
(\mathrm{KEV})\end{array}$ & $\begin{array}{l}\text { DETECT. } \\
\text { LIMIT }\end{array}$ & $\begin{array}{l}\text { ELEMENTAL } \\
\text { CONC. }\end{array}$ & $\begin{array}{c}\text { ELEMENTAL } \\
\mathrm{MASS} \\
\mu \mathrm{g} / \mathrm{cm}^{2}\end{array}$ & $\begin{array}{c}\text { MASS/VOL-1 } \\
\mu \mathrm{gg} / \mathrm{m}^{3}\end{array}$ & $\begin{array}{c}\text { MASS/VOL-2 } \\
\mu \mathrm{g} / \mathrm{m}^{3}\end{array}$ \\
\hline ALUMINUM & 1.487 & 0.0061 & 0.027435 & 0.123941 & 4.904523 & 4.486664 \\
\hline SILICON & 1.74 & 0.0038 & 0.032507 & 0.146854 & 5.811223 & 5.316115 \\
\hline PHOSPHORUS & 0 & 0 & 0 & 0 & 0 & 0 \\
\hline SULFUR & 2.308 & 0.0028 & 0.00886 & 0.040026 & 1.583886 & 1.448941 \\
\hline CHLORINE & 2.622 & 0.0026 & 0.006248 & 0.028226 & 1.116943 & 1.021781 \\
\hline POTASSIUM & 3.314 & 0.0018 & 0.00274 & 0.012378 & 0.489815 & 0.448084 \\
\hline CALCIUM & 3.692 & 0.0018 & 0.002383 & 0.010765 & 0.425986 & 0.389693 \\
\hline TITANIUM & 4.511 & 0.0012 & 0.001136 & 0.005132 & 0.203081 & 0.185778 \\
\hline VANADIUM & 0 & 0 & 0 & 0 & 0 & 0 \\
\hline CHROMIUM & 5.415 & 0.0004 & 0.001457 & 0.006582 & 0.260459 & 0.238268 \\
\hline MANGANESE & 0 & 0 & 0 & 0 & 0 & 0 \\
\hline IRON & 6.399 & 0.0002 & 0.004755 & 0.021481 & 0.850034 & 0.777612 \\
\hline NICKEL & 0 & 0 & 0 & 0 & 0 & 0 \\
\hline COPPER & 8.041 & 0.0001 & 0.000197 & 0.00089 & 0.035219 & 0.032218 \\
\hline ZINC & 8.631 & 0.0002 & 0.001327 & 0.005995 & 0.237231 & 0.217019 \\
\hline BROMINE & 11.924 & 0.0004 & 0.410345 & 1.853784 & 73.35689 & 67.10698 \\
\hline STRONTIUM & 0 & 0 & 0 & 0 & 0 & 0 \\
\hline MOLYBDENUM & 0 & 0 & 0 & 0 & 0 & 0 \\
\hline CADMIUM & 0 & 0 & 0 & 0 & 0 & 0 \\
\hline ANTIMONY & 0 & 0 & 0 & 0 & 0 & 0 \\
\hline LEAD & 10.552 & 0.1008 & 0.000611 & 0.00276 & 0.109217 & 0.099912 \\
\hline
\end{tabular}


SAMPLE NO.: NP 10

SAMPLE DATE: 04/21/88

CORE HOLE: AC-2

LOCATION: On face, between collar $(\sim 5 \mathrm{ft})$ and DCT
MASS $\mu \mathrm{g} / \mathrm{cm}^{2}: 5.884412$

FILTER AREA-1 $\left(\mathrm{cm}^{2}\right): 4.155$

FILTER AREA-2 $\left(\mathrm{cm}^{2}\right): 3.801$

AIR VOLUME-1 $\left(\mathrm{m}^{3}\right): 0.1$

AIR VOLUME-2 $\left(\mathrm{m}^{3}\right): 0.1$

\begin{tabular}{|c|c|c|c|c|c|c|}
\hline ELEMENTS & $\begin{array}{l}\text { ENERGY } \\
\text { (KEV) }\end{array}$ & $\begin{array}{l}\text { DETECT. } \\
\text { LIMIT }\end{array}$ & $\begin{array}{l}\text { ELEMENTAL } \\
\text { CONC. }\end{array}$ & $\begin{array}{c}\text { ELEMENTAL } \\
\text { MASS } \\
\mu \mathrm{g} / \mathrm{cm}^{2}\end{array}$ & $\begin{array}{l}\text { MASS/YOL-1 } \\
\mu \mathrm{g} / \mathrm{m}^{3}\end{array}$ & $\begin{array}{c}\text { MASS/VOL-2 } \\
\mu g / \mathrm{m}^{3}\end{array}$ \\
\hline ALUMINUM & 1.487 & 0.0046 & 0.021166 & 0.124549 & 5.175011 & 4.734108 \\
\hline SILICON & 1.74 & 0.0029 & 0.066941 & 0.393908 & 16.36688 & 14.97244 \\
\hline PHOSPHORUS & 0 & $\mathbf{0}$ & 0 & 0 & 0 & 0 \\
\hline SULFUR & 2.308 & 0.0022 & 0.014941 & 0.087919 & 3.653035 & 3.341801 \\
\hline CHLORINE & 2.622 & 0.002 & 0.005845 & 0.034394 & 1.429071 & 1.307316 \\
\hline POTASSIUM & 3.314 & 0.0014 & 0.009177 & 0.054001 & 2.243742 & 0.052578 \\
\hline CALCIUM & 3.692 & 0.0014 & 0.009669 & 0.056896 & 2.364029 & 0.162617 \\
\hline TITANIUM & 4.511 & 0.001 & 0.001325 & 0.007797 & 0.323965 & 0.296364 \\
\hline VANADIUM & 0 & 0 & 0 & 0 & 0 & 0 \\
\hline CHROMIUM & 5.415 & 0.0003 & 0.001226 & 0.007214 & 0.299742 & 0.274204 \\
\hline MANGANESE & 5.899 & 0.0002 & 0.000497 & 0.002925 & 0.121534 & 0.111179 \\
\hline IRON & 6.399 & 0.0002 & 0.039697 & 0.233594 & 9.705831 & 8.878908 \\
\hline NICKEL & 0 & 0 & 0 & 0 & 0 & 0 \\
\hline COPPER & 8.041 & 0.0001 & 0.000216 & 0.001271 & 0.05281 & 0.048311 \\
\hline ZINC & 8.631 & 0.0001 & 0.001517 & 0.008927 & 0.370917 & 0.339315 \\
\hline BROMINE & 11.924 & 0.0005 & 0.32721 & 1.925438 & 80.00195 & 73.1859 \\
\hline STRONTIUM & 0 & 0 & 0 & 0 & 0 & 0 \\
\hline MOLYBDENUM & 0 & 0 & 0 & 0 & 0 & 0 \\
\hline CADMIUM & 0 & 0 & 0 & 0 & 0 & 0 \\
\hline ANTIMONY & 0 & 0 & 0 & 0 & 0 & 0 \\
\hline LEAD & 10.552 & 0.0006 & 0.000575 & 0.003384 & 0.140605 & 0.128626 \\
\hline
\end{tabular}


SAMPLE NO.: NP 14

SAMPLE DATE: 04/21/88

CORE HOLE: AC-2

LOCATION: On DCT front
MASS $\mu g / \mathrm{cm}^{2}: 10.50574$

FILTER AREA-1 $\left(\mathrm{cm}^{2}\right): 4.155$

FILTER AREA-2 $\left(\mathrm{cm}^{2}\right): 3.801$

AIR VOLUME-1 $\left(\mathrm{m}^{3}\right): 0.44$

AIR VOLUME-2 $\left(\mathrm{m}^{3}\right)$ : 0.44

\begin{tabular}{|c|c|c|c|c|c|c|}
\hline ELEMENTS & $\begin{array}{l}\text { ENERGY } \\
\text { (KEV) }\end{array}$ & $\begin{array}{l}\text { DETECT. } \\
\text { LIMIT }\end{array}$ & $\begin{array}{l}\text { ELEMENTAL } \\
\text { CONC. }\end{array}$ & $\begin{array}{l}\text { ELEMENTAL } \\
\text { MASS } \\
\mu g / \mathrm{cm}^{2}\end{array}$ & $\begin{array}{l}\text { MASS/YOL-1 } \\
\mu \mathrm{g} / \mathrm{m}^{3}\end{array}$ & $\begin{array}{c}\text { MASS/YOL-2 } \\
\mu \mathrm{g} / \mathrm{m}^{3}\end{array}$ \\
\hline ALUMINUM & 1.487 & 0.0035 & 0.031256 & 0.328367 & 3.100829 & 2.836643 \\
\hline SILICON & 1.74 & 0.0022 & 0.139157 & 1.461947 & 13.80543 & 12.62923 \\
\hline PHOSPHORUS & 2.014 & 0.0018 & 0.001568 & 0.016473 & 0.155558 & 0.142304 \\
\hline SULFUR & 2.308 & 0.0016 & 0.019957 & 0.209663 & 1.979886 & 1.811202 \\
\hline CHLORINE & 2.622 & 0.0014 & 0.006211 & 0.065251 & 0.616177 & 0.56368 \\
\hline POTASSIUM & 3.314 & 0.0011 & 0.02154 & 0.226294 & 2.136936 & 1.954872 \\
\hline CALCIUM & 3.692 & 0.0012 & 0.018201 & 0.191215 & 1.805678 & 1.651837 \\
\hline TTTANIUM & 4.511 & 0.0006 & 0.0017 & 0.01786 & 0.168655 & 0.154286 \\
\hline VANADIUM & 0 & 0 & 0 & 0 & 0 & 0 \\
\hline CHROMIUM & 5.415 & 0.0002 & 0.000704 & 0.007396 & 0.069842 & 0.063891 \\
\hline MANGANESE & 5.899 & 0.0001 & 0.001283 & 0.013479 & 0.127285 & 0.11644 \\
\hline IRON & 6.399 & 0.0001 & 0.078195 & 0.821496 & 7.757537 & 7.096605 \\
\hline NICKEL & 7.472 & $\mathbf{0}$ & 0.000064 & 0.000672 & 0.006346 & 0.005805 \\
\hline COPPER & 8.041 & 1 & 0.000332 & 0.003488 & 0.032938 & 0.030132 \\
\hline ZINC & 8.631 & 0.0001 & 0.0018 & 0.01891 & 0.178571 & 0.163357 \\
\hline BROMINE & 11.924 & 0.0003 & 0.177602 & 1.86584 & 17.61947 & 16.11831 \\
\hline STRONTIUM & 0 & 0 & 0 & 0 & 0 & $\mathbf{0}$ \\
\hline MOL YBDENUM & 0 & 0 & 0 & $\mathbf{0}$ & 0 & 0 \\
\hline CADMIUM & 0 & 0 & 0 & 0 & 0 & 0 \\
\hline ANTTMONY & 0 & 0 & 0 & 0 & 0 & 0 \\
\hline LEAD & 10.552 & 0.0003 & 0.000043 & 0.004517 & 0.042655 & 0.039021 \\
\hline
\end{tabular}


SAMPLE NO.: NP 22

MASS $\mu \mathrm{g} / \mathrm{cm}^{2}: 4.653607$

SAMPLE DATE: 04/20/88

FILTER AREA-1 $\left(\mathrm{cm}^{2}\right): 0$

FILTER AREA-2 $\left(\mathrm{cm}^{2}\right): 3.801$

CORE HOLE: AC-2

AIR VOLUME-1 $\left(\mathrm{m}^{3}\right): 0.414$

LOCATION: On wire (middle of personnel area)

AIR VOLUME-2 $\left(\mathrm{m}^{3}\right)$ : 0.414

\begin{tabular}{|c|c|c|c|c|c|c|}
\hline \multirow[b]{2}{*}{ ELEMENTS } & \multirow[b]{2}{*}{$\begin{array}{c}\text { ENERGY } \\
\text { (KEV) }\end{array}$} & \multicolumn{5}{|c|}{ ELEMENTAL } \\
\hline & & $\begin{array}{l}\text { DETECT. } \\
\text { LIMTT }\end{array}$ & $\begin{array}{l}\text { ELEMENTAL } \\
\text { CONC. }\end{array}$ & $\begin{array}{l}\text { MASS } \\
\mu \mathrm{g} / \mathrm{cm}^{2}\end{array}$ & $\begin{array}{l}\text { MASS/YOL-1 } \\
\mu \mathrm{g} / \mathrm{m}^{3}\end{array}$ & $\begin{array}{c}\text { MASS/VOL-2 } \\
\mu \mathrm{g} / \mathrm{m}^{3}\end{array}$ \\
\hline ALUMINUM & 1.487 & 0.0091 & 0.01294 & 0.060218 & 0 & 0.552871 \\
\hline SILICON & 1.74 & 0.0056 & 0.023478 & 0.109257 & 0 & 1.003106 \\
\hline PHOSPHORUS & 0 & 0 & 0 & 0 & 0 & 0 \\
\hline SULFUR & 2.308 & 0.004 & 0.008888 & 0.041361 & $\mathbf{0}$ & 0.379742 \\
\hline CHLORINE & 2.622 & 0.0036 & 0.009182 & 0.042729 & 0 & 0.392302 \\
\hline POTASSIUM & 3.314 & 0.0028 & 0.002697 & 0.012551 & 0 & 0.115233 \\
\hline CALCIUM & 3.692 & 0.0029 & 0.004056 & 0.018875 & 0 & 0.173294 \\
\hline TITANIUM & 4.511 & 0.0012 & 0.000726 & 0.003379 & 0 & 0.031023 \\
\hline VANADIUM & 0 & 0 & 0 & 0 & 0 & 0 \\
\hline CHROMIUM & 5.415 & 0.0003 & 0.002475 & 0.011518 & $\mathbf{0}$ & 0.105749 \\
\hline MANGANESE & 5.899 & 0.0003 & 0.000332 & 0.001545 & 0 & 0.014185 \\
\hline IRON & 6.399 & 0.0002 & 0.014094 & 0.065588 & 0 & 0.602174 \\
\hline NICKEL & 7.472 & 0.0001 & 0.000067 & 0.000312 & 0 & 0.002865 \\
\hline COPPER & 8.041 & 0.0001 & 0.000142 & 0.000661 & 0 & 0.006069 \\
\hline ZINC & 8.631 & 0.0001 & 0.001372 & 0.006385 & 0 & 0.058622 \\
\hline BROMINE & 11.924 & 0.0004 & 0.418826 & 1.949052 & 0 & 17.89456 \\
\hline STRONTIUM & 0 & $\mathbf{0}$ & 0 & 0 & 0 & 0 \\
\hline MOLYBDENUM & 0 & 0 & 0 & 0 & 0 & 0 \\
\hline CADMIUM & 0 & 0 & 0 & 0 & 0 & 0 \\
\hline ANTIMONY & 0 & 0 & 0 & 0 & 0 & 0 \\
\hline LEAD & 10.552 & 0.0005 & 0.000767 & 0.003569 & 0 & 0.032768 \\
\hline
\end{tabular}




\begin{tabular}{|c|c|c|c|c|c|c|}
\hline ELEMENTS & $\begin{array}{l}\text { ENERGY } \\
\text { (KEV) }\end{array}$ & $\begin{array}{l}\text { DETECT. } \\
\text { LIMIT }\end{array}$ & $\begin{array}{l}\text { ELEMENTAL } \\
\text { CONC. }\end{array}$ & $\begin{array}{l}\text { ELEMENTAL } \\
\text { MASS } \\
\mu \mathrm{g} / \mathrm{cm}^{2}\end{array}$ & $\begin{array}{l}\text { MASS/VOL-1 } \\
\mu \mathrm{g} / \mathrm{m}^{3}\end{array}$ & $\begin{array}{c}\text { MASS/VOL-2 } \\
\mu \mathrm{g} / \mathrm{m}^{3}\end{array}$ \\
\hline ALUMINUM & 1.487 & 0.0093 & 0.023129 & 0.106408 & 0 & 1.907815 \\
\hline SILICON & 1.74 & 0.0057 & 0.028947 & 0.133178 & 0 & 2.387781 \\
\hline PHOSPHORUS & 0 & 0 & 0 & 0 & 0 & 0 \\
\hline SULFUR & 2.308 & 0.0044 & 0.005996 & 0.027584 & 0 & 0.49456 \\
\hline CHLORINE & 2.622 & 0.0038 & 0.005696 & 0.026206 & 0 & 0.469854 \\
\hline POTASSIUM & 3.314 & 0.003 & 0.003893 & 0.017911 & 0 & 0.321131 \\
\hline CALCIUM & 3.692 & 0.003 & 0.003867 & 0.017791 & 0 & 0.318979 \\
\hline TITANIUM & 4.511 & 0.0012 & 0.001336 & 0.006147 & 0 & 0.110211 \\
\hline VANADIUM & 0 & 0 & 0 & 0 & 0 & 0 \\
\hline CHROMIUM & 5.415 & 0.0003 & 0.002717 & 0.0125 & 0 & 0.224116 \\
\hline MANGANESE & 5.899 & 0.0003 & 0.000148 & 0.000681 & $\mathbf{0}$ & 0.01221 \\
\hline IRON & 6.399 & 0.0002 & 0.010691 & 0.04918 & 0 & 0.88176 \\
\hline NICKEL & 7.472 & 0.0001 & 0.000089 & 0.000409 & 0 & 0.007333 \\
\hline COPPER & 8.041 & 0.0001 & 0.000147 & 0.000678 & 0 & 0.012156 \\
\hline ZINC & 8.631 & 0.0001 & 0.001279 & 0.005884 & 0 & 0.105496 \\
\hline BROMINE & 11.924 & 0.0005 & 0.411347 & 1.892489 & 0 & 33.9309 \\
\hline STRONTIUM & 0 & 0 & 0 & 0 & 0 & 0 \\
\hline MOLYBDENUM & 0 & 0 & 0 & 0 & 0 & 0 \\
\hline CADMIUM & 0 & 0 & 0 & 0 & 0 & 0 \\
\hline ANTIMONY & 0 & 0 & 0 & 0 & 0 & 0 \\
\hline LEAD & 10.552 & 0.0005 & 0.00076 & 0.003497 & 0 & 0.062699 \\
\hline
\end{tabular}


SAMPLE NO.: NP 32B

SAMPLE DATE: 04/28/88

CORE HOLE: AC-2

LOCATION: BLIND BLANK - PIXE sample set
MASS $\mu g / \mathrm{cm}^{2}: 4.146936$

FILT:R AREA-1 $\left(\mathrm{cm}^{2}\right): 0$

FILTER AREA-2 $\left(\mathrm{cm}^{2}\right): 3.801$

AIR VOLUME-1 $\left(\mathrm{m}^{3}\right)$ : 0

AIR VOLUME- $2\left(\mathrm{~m}^{3}\right): 0.232$

\begin{tabular}{|c|c|c|c|c|c|c|}
\hline \multirow[b]{2}{*}{ ELEMENTS } & \multirow[b]{2}{*}{$\begin{array}{l}\text { ENERGY } \\
\text { (KEV) }\end{array}$} & \multicolumn{5}{|c|}{ ELEMENTAL } \\
\hline & & $\begin{array}{l}\text { DETECT. } \\
\text { LIMIT }\end{array}$ & $\begin{array}{l}\text { ELEMENTAL } \\
\text { CONC. }\end{array}$ & ${ }_{\mu \mathrm{g} / \mathrm{cm}^{2}}^{\text {MASS }}$ & $\underset{\mu \mathrm{gASS} / \mathrm{m}^{3}}{\text { MAL-1 }}$ & $\underset{\mu \mathrm{MASS} / \mathrm{m}^{3}}{\mathrm{MOL-2}}$ \\
\hline ALUMINUM & 0 & 0 & 0 & 0 & $\mathbf{0}$ & 0 \\
\hline SILICON & 1.74 & 0.0059 & 0.007166 & 0.029717 & 0 & 0.486872 \\
\hline PHOSPHORUS & 0 & 0 & 0 & 0 & 0 & 0 \\
\hline SULFUR & 2.308 & 0.0046 & 0.00796 & 0.03301 & 0 & 1.540823 \\
\hline CHLORINE & 2.622 & 0.0042 & 0.00676 & 0.028033 & $\mathbf{0}$ & 0.459282 \\
\hline POTASSIUM & 0 & 0 & 0 & 0 & 0 & 0 \\
\hline CALCIUM & 0 & 0 & 0 & 0 & 0 & D \\
\hline TITANIUM & 4.511 & 0.0013 & 0.001035 & 0.004292 & 0 & 0.070319 \\
\hline VANADIUM & 0 & 0 & 0 & 0 & 0 & $\mathbf{0}$ \\
\hline CHROMIUM & 5.415 & 0.0004 & 0.001306 & 0.005416 & 0 & 0.088734 \\
\hline MANGANESE & 0 & 0 & 0 & 0 & 0 & 0 \\
\hline IRON & 6.399 & 0.0002 & 0.000571 & 0.002368 & $\mathbf{0}$ & 0.038796 \\
\hline NICKEL & 0 & 0 & 0 & $\mathbf{0}$ & 0 & 0 \\
\hline COPPER & 8.041 & 0.0001 & 0.000131 & 0.000543 & $\mathbf{0}$ & 0.008896 \\
\hline ZINC & 8.631 & 0.0001 & 0.000628 & 0.002604 & $\mathbf{0}$ & 0.042663 \\
\hline BROMINE & 11.924 & 0.0005 & 0.474122 & 1.966154 & 0 & 32.21272 \\
\hline STRONTIUM & 0 & 0 & 0 & 0 & 0 & 0 \\
\hline MOLYBDENUM & $\mathbf{0}$ & 0 & $\mathbf{0}$ & 0 & 0 & 0 \\
\hline CADMIUM & 0 & 0 & $\mathbf{0}$ & 0 & 0 & 0 \\
\hline ANTMMONY & 0 & 0 & 0 & 0 & 0 & 0 \\
\hline LEAD & 10.552 & 0.0006 & 0.000321 & 0.001331 & 0 & 0.021807 \\
\hline
\end{tabular}


SAMPLE NO.: NP 47B

SAMPLE DATE: 04/12/88

CORE HOLE: AC-2

LOCATION: BLIND BLANK - PIXE sample set
MASS $\mu g / \mathrm{cm}^{2}: 2.181741$

FILTER AREA $1\left(\mathrm{~cm}^{2}\right): 4.155$

FILIER AREA-2 $\left(\mathrm{cm}^{2}\right): 3.801$

AIR VOLUME-1 $\left(\mathrm{m}^{3}\right): 0.06$

A.IR VOLUME-2 $\left(\mathrm{m}^{3}\right): 0.06$

\begin{tabular}{|c|c|c|c|c|c|c|}
\hline ELEMENTS & $\begin{array}{l}\text { ENERGY } \\
\text { (KEV) }\end{array}$ & $\begin{array}{l}\text { DETECT. } \\
\text { LIMIT }\end{array}$ & $\begin{array}{l}\text { ELEMENTAL } \\
\text { CONC. }\end{array}$ & $\begin{array}{c}\text { ELEMENTAL } \\
\text { MASS } \\
\mu g / \mathrm{cm}^{2}\end{array}$ & $\begin{array}{c}\text { MASS/VOL-1 } \\
\mu \mathrm{gg} / \mathrm{m}^{3}\end{array}$ & $\begin{array}{c}\text { MASSNOL-2 } \\
\mu \mathrm{g} / \mathrm{m}^{3}\end{array}$ \\
\hline ALUMINUM & 1.487 & 0.0208 & 0.052017 & 0.113488 & 7.859045 & 7.16558 \\
\hline SILICON & 1.74 & 0.0131 & 0.030843 & 0.067291 & 4.659902 & 4.248723 \\
\hline PHOSPHORUS & 0 & $\mathbf{0}$ & 0 & 0 & 0 & 0 \\
\hline SULFUR & 2.308 & 0.0096 & 0.018948 & 0.04134 & 2.862795 & 2.610189 \\
\hline CHLORINE & 2.622 & 0.0087 & 0.013089 & 0.028557 & 1.977572 & 1.803076 \\
\hline POTASSIUM & 0 & 0 & 0 & 0 & 0 & 0 \\
\hline CALCIUM & 0 & 0 & 0 & 0 & 0 & 0 \\
\hline TITANIUM & 4.511 & 0.0037 & 0.001116 & 0.002435 & 0.168624 & 0.153745 \\
\hline VANADIUM & 4.952 & 0.002 & 0.000486 & 0.00106 & 0.073405 & 0.056928 \\
\hline CHROMIUM & 5.415 & 0.0011 & 0.003909 & 0.008528 & 0.590564 & 0.538454 \\
\hline MANGANESE & 0 & 0 & 0 & 0 & 0 & 0 \\
\hline IRON & 6.399 & 0.0005 & 0.001499 & 0.00327 & 0.226448 & 0.206466 \\
\hline NICKEI & 7.472 & 0.0004 & 0.000249 & 0.000543 & 0.037603 & 0.034285 \\
\hline COPPER & 8.041 & 0.0003 & 0.000312 & 0.000581 & 0.047159 & 0.042998 \\
\hline ZINC & 8.631 & 0.0004 & 0.002066 & 0.004507 & 0.31211 & 0.28457 \\
\hline BROMINE & 11.924 & 0.0016 & 0.858455 & 1.872926 & 129.7001 & 118.2557 \\
\hline STRONTIUM & 0 & 0 & 0 & 0 & 0 & 0 \\
\hline MOLYBDENUM & 0 & 0 & 0 & $\mathbf{0}$ & 0 & 0 \\
\hline CADMIUM & 23.174 & 0.0158 & 0.0027 & 0.005891 & 0.407952 & 0.371955 \\
\hline ANTIMONY & 26.359 & 0.0305 & 0.013297 & 0.029011 & 2.009012 & 1.831741 \\
\hline LEAD & 10.552 & 0.002 & 0.000993 & 0.002166 & 0.149996 & 0.13676 \\
\hline
\end{tabular}


SAMPLE NO.: NP 52

SAMPLE DATE: 03/29/88

CORE HOLE: AC-2

LOCATION: PERSONAL SAMPLE on Investigator
MASS $\mu \mathrm{g} / \mathrm{cm}^{2}: 0.547707$

FILTER AREA-1 $\left(\mathrm{cm}^{2}\right): 4.155$

FILTER AREA-2 $\left(\mathrm{cm}^{2}\right): 3.801$

AIR VOLUME-1 $\left(\mathrm{m}^{3}\right): 0.126$

AIR VOLUME- $2\left(\mathrm{~m}^{3}\right) ; 0.126$

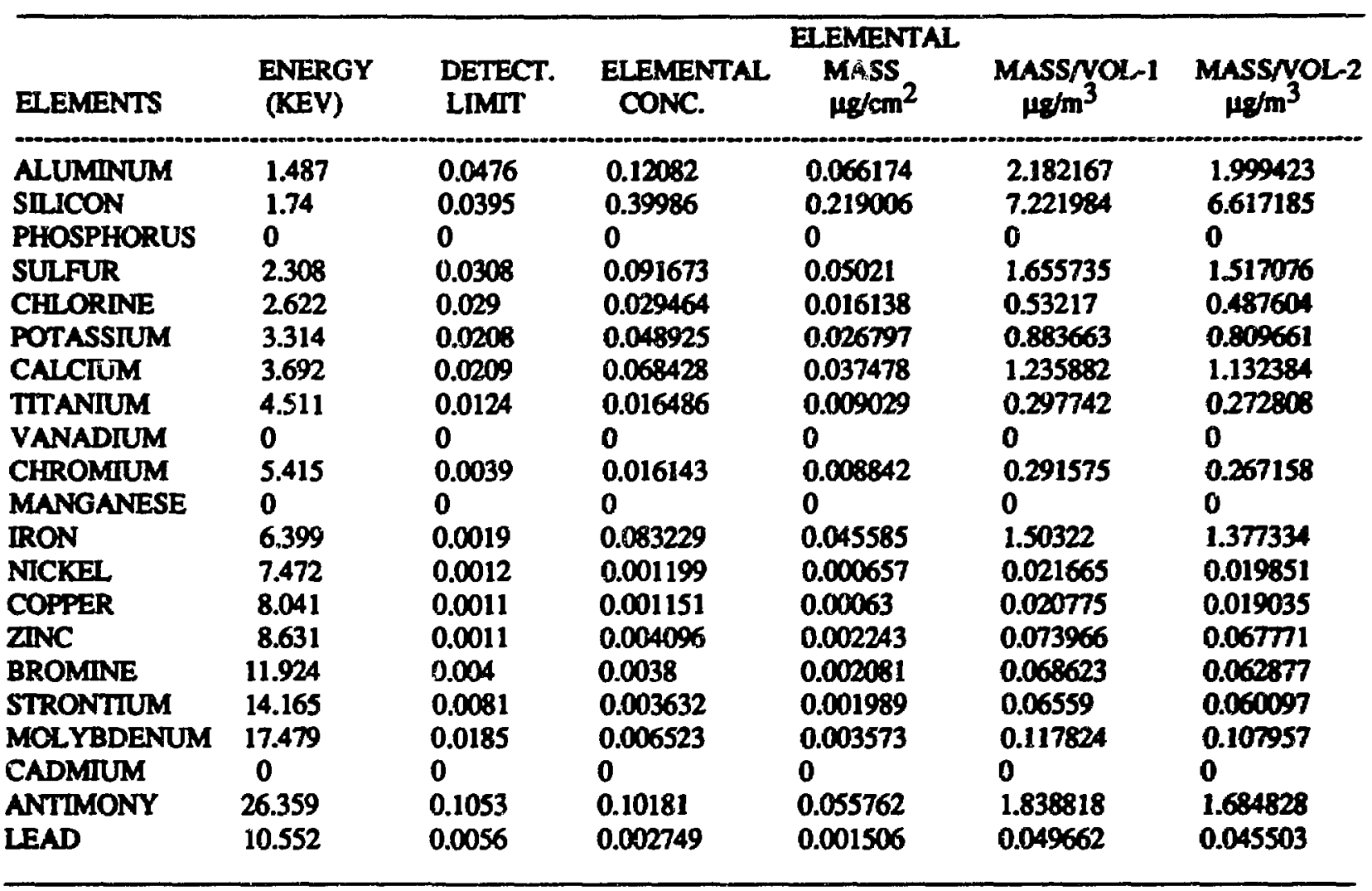


SAMPLE NO.: NP 55

SAMPLE DATE: $03 / 30 / 88$

CORE HOLE: AC-2

LOCATION: On wall of Extens/Demonstrative curve
MASS $\mu \mathrm{g} / \mathrm{cm}^{2}: 2.39308$

FILTER AREA-1 $\left(\mathrm{cm}^{2}\right): 4.155$

FILTER AREA-2 $\left(\mathrm{cm}^{2}\right): 3.801$

AIR VOLUME-1 $\left(\mathrm{m}^{3}\right): 1$

AIR VOLUME-2 $\left(\mathrm{m}^{3}\right): 1266$

\begin{tabular}{|c|c|c|c|c|c|c|}
\hline ELEMENTS & $\begin{array}{l}\text { ENERGY } \\
\text { (KEV) }\end{array}$ & $\begin{array}{l}\text { DETECT. } \\
\text { LIMIT }\end{array}$ & $\begin{array}{l}\text { ELEMENTAL } \\
\text { CONC. }\end{array}$ & $\begin{array}{c}\text { ELEMENTAL } \\
\text { MASS } \\
\mu \mathrm{g} / \mathrm{cm}^{2}\end{array}$ & $\begin{array}{c}\text { MASS NOL-1 } \\
\mu \mathrm{g} / \mathrm{m}^{3}\end{array}$ & $\begin{array}{c}\text { MASS } N O L-2 \\
\mu \mathrm{g} / \mathrm{m}^{3}\end{array}$ \\
\hline ALUMNUM & 1.487 & 0.0171 & 0.044661 & 0.106877 & 0.444074 & 0.000321 \\
\hline SILICON & 1.74 & 0.0107 & 0.048268 & 0.115509 & 5.47994 & 0.000347 \\
\hline PHOSPHORUS & 0 & 0 & 0 & 0 & 0 & 0 \\
\hline SULFUR & 2.308 & 0.0078 & 0.021307 & 0.050989 & 0.211859 & 0.000153 \\
\hline CHLORINE & 2.622 & 0.0073 & 0.012649 & 0.03027 & 0.125772 & 0.000091 \\
\hline POTASSIUM & 0 & 0 & 0 & 0 & 0 & 0 \\
\hline CALCIUM & 3.692 & 0.0053 & 0.006179 & 0.014787 & 0.06144 & 0.000044 \\
\hline TITANIUM & 4.511 & 0.0028 & 0.002612 & 0.006251 & 0.025973 & 0.000019 \\
\hline VANADIUM & 0 & 0 & 0 & 0 & 0 & 0 \\
\hline CHROMIUM & 5.415 & 0.0009 & 0.005383 & 0.012882 & 0.053525 & 0.000039 \\
\hline MANGANESE & 0 & 0 & 0 & 0 & 0 & 0 \\
\hline IRON & 6.399 & 0.0005 & 0.010261 & 0.024555 & 0.102026 & 0.000074 \\
\hline NICKEL & 0 & 0 & 0 & 0 & 0 & 0 \\
\hline COPPER & 8.041 & 0.0003 & 0.000208 & 0.000498 & 0.002069 & 0.000001 \\
\hline ZINC & 8.631 & 0.0003 & 0.00185 & 0.004427 & 0.018394 & 0.000013 \\
\hline BROMINE & 11.924 & 0.0004 & 0.824721 & 1.973623 & 8.200404 & 0.005926 \\
\hline STRONTIUM & 0 & 0 & 0 & 0 & 0 & 0 \\
\hline MOLYBDENUM & 0 & 0 & 0 & 0 & 0 & 0 \\
\hline CADMIUM & 23.174 & 0.0146 & 0.006635 & 0.015878 & 0.065973 & 0.000048 \\
\hline ANTIMONY & 26.359 & 0.0239 & 0.013921 & 0.033314 & 0.13842 & 0.0001 \\
\hline LEAD & 10.552 & 0.0015 & 0.001346 & 0.003221 & 0.013383 & 0.00001 \\
\hline
\end{tabular}


SAMPLE NO.: NP 56

SAMPLE DATE: 04/19/88

CORE HOLE: AC-2

LOCATION: On face $-6.5 \mathrm{ft}$ Right of collar and $7 \mathrm{ft}$ from DCT
MASS $\mu \mathrm{g} / \mathrm{cm}^{2}: 5.136017$

FILTER AREA-1 $\left(\mathrm{cm}^{2}\right): 0$

FILTER AREA-2 $\left(\mathrm{cm}^{2}\right): 3.801$

AIR VOLUME-1 $\left(\mathrm{m}^{3}\right): 0$

AIR VOLUME-2 $\left(\mathrm{m}^{3}\right): 0.242$

\begin{tabular}{|c|c|c|c|c|c|c|}
\hline ELEMENTS & $\begin{array}{l}\text { ENERGY } \\
\text { (KEV) }\end{array}$ & $\begin{array}{l}\text { DETECT. } \\
\text { LIMIT }\end{array}$ & $\begin{array}{l}\text { ELEMENTAL } \\
\text { CONC. }\end{array}$ & $\begin{array}{c}\text { ELEMENTAL } \\
\mathrm{MASS} \\
\mu \mathrm{g} / \mathrm{cm}^{2}\end{array}$ & $\begin{array}{c}\text { MASS/VOL-1 } \\
\mu \mathrm{g} / \mathrm{m}^{3}\end{array}$ & $\begin{array}{c}\text { MASS/NOL-2 } \\
\mu \mathrm{g} / \mathrm{m}^{3}\end{array}$ \\
\hline ALUMINIM & 1.487 & 0.0083 & 0.020348 & 0.104508 & 0 & 1.641467 \\
\hline SILICON & 1.74 & 0.0051 & 0.044632 & 0.229231 & 0 & 3.600442 \\
\hline PHOSPHORUS & 0 & 0 & 0 & 0 & 0 & 0 \\
\hline SULFUR & 2.308 & 0.0037 & 0.009088 & 0.046676 & 0 & 0.733122 \\
\hline CHLORINE & 2.622 & 0.0034 & 0.00653 & 0.033538 & 0 & 0.526768 \\
\hline POTASSIUM & 3.314 & 0.0027 & 0.006687 & 0.034345 & 0 & 0.539444 \\
\hline CALCIUM & 3.692 & 0.0026 & 0.005266 & 0.027046 & 0 & 0.424801 \\
\hline TITANIUM & 4.511 & 0.0011 & 0.001213 & 0.00623 & 0 & 0.097852 \\
\hline VANADIUM & 0 & 0 & 0 & 0 & 0 & 0 \\
\hline CHROMIUM & 5.415 & 0.0003 & 0.001874 & 0.009625 & 0 & 0.151176 \\
\hline MANGANESE & 5.899 & 0.0002 & 0.00032 & 0.001644 & 0 & 0.025822 \\
\hline IRON & 6.399 & 0.0002 & 0.015428 & 0.079238 & 0 & 1.244561 \\
\hline NICKEL & 7.472 & 0.0001 & 0.000072 & 0.00037 & 0 & 0.005811 \\
\hline COPPER & 8.041 & 0.0001 & 0.000179 & 0.000919 & 0 & 0.014434 \\
\hline ZINC & 8.631 & 0.0001 & 0.001116 & 0.005732 & 0 & 0.09003 \\
\hline BROMINE & 11.924 & 0.0004 & 0.38664 & 1.98579 & 0 & 31.19003 \\
\hline STRONTIUM & 0 & 0 & 0 & 0 & 0 & 0 \\
\hline MOLYBDENUM & 0 & 0 & 0 & 0 & 0 & 0 \\
\hline CADMIUM & 0 & 0 & 0 & 0 & 0 & 0 \\
\hline ANTIMONY & 0 & 0 & 0 & 0 & 0 & 0 \\
\hline LEAD & 10.552 & 0.0005 & 0.000607 & 0.003118 & 0 & 0.048973 \\
\hline
\end{tabular}


SAMPLE NO.: NP 59

SAMPLE DATE: 03/30/88

CORE HOLE: AC-1

LOCATION: Left wall ( $\sim 8 \mathrm{ft}$ from face) even with drill
MASS $\mu \mathrm{g} / \mathrm{cm}^{2}: 2.762536$

FILTER AREA-1 $\left(\mathrm{cm}^{2}\right): 4.155$

FILTER AREA-2 $\left(\mathrm{cm}^{2}\right): 3.801$

AIR VOLUME-1 $\left(\mathrm{m}^{3}\right): 1$

AIR VOLUME-2 $\left(\mathrm{m}^{3}\right): 0.061$

\begin{tabular}{|c|c|c|c|c|c|c|}
\hline ELEMENTS & $\begin{array}{l}\text { ENERGY } \\
\text { (KEV) }\end{array}$ & $\begin{array}{l}\text { DETECT. } \\
\text { LIMIT }\end{array}$ & $\begin{array}{l}\text { ELEMENTAL } \\
\text { CONC. }\end{array}$ & $\begin{array}{c}\text { ELEMENTAL } \\
\text { MASS } \\
\mu \mathrm{g} / \mathrm{cm}^{2}\end{array}$ & $\underset{\mu \mathrm{MASS} / \mathrm{m}^{3}}{\underset{3}{\text { MaL } 1}}$ & $\begin{array}{c}\text { MASSNNOL-2 } \\
\mu g / m^{3}\end{array}$ \\
\hline ALUMMIUM & 1.487 & 0.0146 & 0.056961 & 0.157357 & 0.653818 & 9.805147 \\
\hline SILICON & 1.74 & 0.009 & 0.153926 & 0.425226 & 1.766814 & 26.49646 \\
\hline PHOSPHORUS & 0 & 0 & 0 & $\mathbf{0}$ & 0 & $\mathbf{0}$ \\
\hline SULFUR & 2.308 & 0.0069 & 0.010648 & 0.029415 & 0.122219 & 1.832892 \\
\hline CHLORINE & 2.622 & 0.0054 & 0.00957 & 0.026437 & 0.109846 & 1.547329 \\
\hline POTASSIUM & 3.314 & 0.0048 & 0.016722 & 0.046195 & 0.19194 & 2.878479 \\
\hline CALCIUM & 3.692 & 0.0046 & 0.005069 & 0.014003 & 0.058182 & 0.872548 \\
\hline TITANIUM & 4.511 & 0.0025 & 0.003357 & 0.009274 & 0.038533 & 0.577877 \\
\hline VANADIUM & 4.952 & 0.0014 & 0.000299 & 0.000826 & 0.003432 & 0.051469 \\
\hline CHROMIUM & 5.415 & 0.0008 & 0.005316 & 0.014686 & 0.06102 & 0.915106 \\
\hline MANGANESE & 0 & 0 & 0 & 0 & 0 & 0 \\
\hline IRON & 6.399 & 0.0004 & 0.013924 & 0.038466 & 0.159826 & 2.396873 \\
\hline NICKEL & 7.472 & 0.0002 & 0.000144 & 0.000398 & 0.001654 & 0.0248 \\
\hline COPPER & 8.041 & 0.0003 & 0.000326 & 0.000901 & 0.003744 & 0.056143 \\
\hline ZWNC & 8.631 & 0.0003 & 0.001747 & 0.004826 & 0.020052 & 0.300715 \\
\hline BROMINE & 11.924 & 0.0013 & 0.697734 & 1.927515 & 8.008825 & 120.1063 \\
\hline STRONTIUM & 0 & 0 & 0 & 0 & $\mathbf{0}$ & 0 \\
\hline MOLYBDENUM & 0 & 0 & 0 & 0 & 0 & 0 \\
\hline CADMIUM & 23.174 & 0.0127 & 0.010751 & 0.0297 & 0.123404 & 1.850651 \\
\hline ANTIMONY & 26.359 & 0.0217 & 0.012866 & 0.035543 & 0.147681 & 2.214737 \\
\hline LEAD & 10.552 & 0.0013 & 0.000641 & 0.001771 & 0.007359 & 0.110354 \\
\hline
\end{tabular}


CORE HOLE: AC-1

LOCATION: BULK SAMPLE \#1 from DCT Bag for Run 7

\begin{tabular}{|c|c|c|c|c|}
\hline ELEMENTS & $\begin{array}{l}\text { ENERGY } \\
\text { (KEV) }\end{array}$ & $\begin{array}{l}\text { DETECT. LIMIT } \\
\text { 959.6 CONFIDENCE }\end{array}$ & $\begin{array}{l}\text { CONCENTRATION } \\
\text { MASS }\end{array}$ & $\begin{array}{c}\text { ERROR } \\
\quad \pm\end{array}$ \\
\hline OXYGEN & & & $49.542 \%$ & $0.609 \%$ \\
\hline SODIUM & 1.041 & $0.195 \%$ & $3.205 \%$ & $1.028 \%$ \\
\hline MAGNESIUM & 1.254 & $836.6 \mathrm{ppm}$ & $0.193 \%$ & $0.143 \%$ \\
\hline ALUMINUM & 1.487 & $446.4 \mathrm{ppm}$ & $6.952 \%$ & $0.483 \%$ \\
\hline SILICON & 1.74 & $324.5 \mathrm{ppm}$ & $32.47 \%$ & $2.140 \%$ \\
\hline CHLORINE & 2.622 & $188.7 \mathrm{ppm}$ & $256.8 \mathrm{ppm}$ & $118.9 \mathrm{ppm}$ \\
\hline POTASSIUM & 3.314 & $170.8 \mathrm{ppm}$ & $4.331 \%$ & $0.288 \%$ \\
\hline CALCIUM & 3.692 & $425.9 \mathrm{ppm}$ & $0.199 \%$ & $0.021 \%$ \\
\hline TITANIUM & 4.511 & $67.9 \mathrm{ppm}$ & $0.168 \%$ & 0.1296 \\
\hline MANGANESE & 5.899 & $12.45 \mathrm{ppm}$ & $0.143 \%$ & $0.010 \%$ \\
\hline IRON & 6.399 & $18.68 \mathrm{ppm}$ & $2.648 \%$ & 0.17496 \\
\hline NICKEL & 7.472 & $5.93 \mathrm{ppm}$ & $7.62 \mathrm{ppm}$ & $2.53 \mathrm{ppm}$ \\
\hline COPPER & 8.041 & $5.46 \mathrm{ppm}$ & $33.63 \mathrm{ppm}$ & $3.78 \mathrm{ppm}$ \\
\hline ZNNC & 8.631 & $5.81 \mathrm{ppm}$ & $205.2 \mathrm{ppm}$ & $14.65 \mathrm{ppm}$ \\
\hline GALLIUM & 9.243 & $4.97 \mathrm{ppm}$ & $18.31 \mathrm{ppm}$ & $2.9 \mathrm{ppm}$ \\
\hline RUBIDIUM & 13.395 & $8.96 \mathrm{ppm}$ & $162.6 \mathrm{ppm}$ & $14.89 \mathrm{ppm}$ \\
\hline STRONTIUM & 14.165 & $9.95 \mathrm{ppm}$ & $16.58 \mathrm{ppm}$ & 5.13 ppm \\
\hline YTTRIUM & 14.958 & $28.05 \mathrm{ppm}$ & $61.36 \mathrm{ppm}$ & $11.68 \mathrm{ppm}$ \\
\hline ZIRCONIUM & 15.775 & $31.21 \mathrm{ppm}$ & $607.8 \mathrm{ppm}$ & $48.01 \mathrm{ppm}$ \\
\hline MOLYBDENUM & 0 & 0 & o & 0 \\
\hline TUNGSTEN & 8.398 & $30.45 \mathrm{ppm}$ & $88.39 \mathrm{ppm}$ & $10.29 \mathrm{ppm}$ \\
\hline LEAD & 10.552 & $11.93 \mathrm{ppm}$ & $44.11 \mathrm{ppm}$ & $7.0 \mathrm{ppm}$ \\
\hline
\end{tabular}


CORE HOLE: AC-1

LOCATION: BULK SAMPLE \#1 from DCT Bag for Runs 8-12

\begin{tabular}{lcccc}
\hline ELEMENTS & $\begin{array}{c}\text { ENERGY } \\
\text { (KEV) }\end{array}$ & $\begin{array}{c}\text { DETECT. LIMIT } \\
95 \% \text { CONFIDENCE }\end{array}$ & $\begin{array}{c}\text { CONCENTRATION } \\
\text { MASS }\end{array}$ & $\begin{array}{c}\text { ERROR } \\
\pm\end{array}$ \\
\hline OXYGEN & & & $0.707 \%$ \\
SODIUM & -1.041 & $45.304 \%$ & $1.188 \%$ \\
MAGNESIUM & 1.254 & $0.212 \%$ & $3.242 \%$ & $0.198 \%$ \\
ALUMNUM & 1.487 & $905.2 \mathrm{ppm}$ & $0.211 \%$ & $0.516 \%$ \\
SILICON & 1.74 & $491.5 \mathrm{ppm}$ & $7.375 \%$ & $2.356 \%$ \\
CHLORINE & 2.622 & $352.2 \mathrm{ppm}$ & $35.76 \%$ & $146.3 \mathrm{ppm}$ \\
POTASSIUM & 3.314 & $221.4 \mathrm{ppm}$ & $342.1 \mathrm{ppm}$ & $0.337 \%$ \\
CALCIUM & $218.8 \mathrm{ppm}$ & $5.057 \%$ & $0.018 \%$ \\
TITANIUM & 3.692 & $468.6 \mathrm{ppm}$ & $0.127 \%$ & $0.012 \%$ \\
MANGANESE & 4.511 & $67.68 \mathrm{ppm}$ & $0.165 \%$ & $0.01 \%$ \\
IRON & 5.899 & $12.1 \mathrm{ppm}$ & $0.146 \%$ & $0.162 \%$ \\
NICKEL & 6.399 & $18.53 \mathrm{ppm}$ & $2.463 \%$ & $2.34 \mathrm{ppm}$ \\
COPPER & 7.472 & $5.69 \mathrm{ppm}$ & $4.39 \mathrm{ppm}$ & $2.65 \mathrm{ppm}$ \\
ZINC & 8.041 & $5.20 \mathrm{ppm}$ & $14.35 \mathrm{ppm}$ & $11.47 \mathrm{ppm}$ \\
GALLIUM & 8.631 & $5.23 \mathrm{ppm}$ & $157.5 \mathrm{ppm}$ & $3.04 \mathrm{ppm}$ \\
RUBIDIUM & 9.243 & $4.975 \mathrm{ppm}$ & $22.36 \mathrm{ppm}$ & $14.01 \mathrm{ppm}$ \\
STRONTIUM & 13.395 & $10.22 \mathrm{ppm}$ & $153.4 \mathrm{ppm}$ & $4.49 \mathrm{ppm}$ \\
YTTRIUM & 14.165 & $11.57 \mathrm{ppm}$ & $12.06 \mathrm{ppm}$ & $11.64 \mathrm{ppm}$ \\
ZIRCONIUM & 14.958 & $26.31 \mathrm{ppm}$ & $70.27 \mathrm{ppm}$ & $47.35 \mathrm{ppm}$ \\
MOLYBDENUM & 15.775 & $28.1 \mathrm{ppm}$ & $607 \mathrm{ppm}$ & $13.92 \mathrm{ppm}$ \\
TUNGSTEN & 17.479 & $59.65 \mathrm{ppm}$ & $29.32 \mathrm{ppm}$ & $8.93 \mathrm{ppm}$ \\
LEAD & 8.398 & $26.3 \mathrm{ppm}$ & $67.16 \mathrm{ppm}$ & $6.12 \mathrm{ppm}$ \\
\hline & 10.552 & $12.73 \mathrm{ppm}$ & $32.23 \mathrm{ppm}$ & \\
\hline
\end{tabular}


APPENDIX D-5

SEM/EDX SAMPLES

SAMPLE NO: NP 27

SAMPLE DATE: 04/21/88

CORE HOLE: AC-2

LOCATION: On wall between DCT and drill collar.

RUN TIME (m): 104

MASS $\left(\mu \mathrm{g} / \mathrm{m}^{3}\right): 4.600712$

AIR VOLUME $\left(\mathrm{m}^{3}\right): 0.212$

FIBERS COUNTED/100 Optical Fields (fibers): 0 FIBER CONC. $\left(\mathrm{f} / \mathrm{cm}^{3}\right): 0$

ANALYTICAL COMMENTS: No Fibers Detected.

SAMPLE NO: NP 22

SAMPLE DATE: 04/20/88

CORE HOLE: AC-2

LOCATION: On wire (middle of personnel area).

RUN TIME (m): 209.5

MASS $\left(\mu \mathrm{g} / \mathrm{m}^{3}\right): 4.653607$

AIR VOL $\left(\mathrm{m}^{3}\right): 0.414$

FIBERS COUNTED/100 Optical Fields (fibers): 0 FIBER CONC. $\left(\mathrm{f} / \mathrm{cm}^{3}\right): 0$

ANAL YTICAL COMMENTS: No Fibers Detected.

SAMPLE NO: NP 56

SAMPLE DATE: 04/19/88

CORE HOLE: AC-2

LOCATION: On face approximately $6.5 \mathrm{ft}$ right of collar approximately $7 \mathrm{ft}$ from $\mathrm{DCT}$.

RUN TIME (m): 120

MASS $\left(\mu \mathrm{g} / \mathrm{m}^{3}\right): 5.136017$

AIR VOLUME $\left(\mathrm{m}^{3}\right): 0$

FIBERS COUNTED 100 Optical Fields (fibers): 0 FIBER CONC. $\left(\mathrm{f} / \mathrm{cm}^{3}\right): 0$

ANALYTICAL COMMENTS: No Fibers Detected.
SAMPLE NO: NP 32B

SAMPLE DATE: $04 / 28 / 88$

CORE HOLE: AC-2

LOCATION: BLIND BLANK - PIXE sample set. RUN TIME (m): 0

MASS $\left(\mu \mathrm{g} / \mathrm{m}^{3}\right): 4.146936$

AIR VOL $\left(\mathrm{m}^{3}\right): 0.232$

FIBERS COUNTED/100 Optical Fields (fibers): 0 FIBERS CONC. $\left(f / \mathrm{cm}^{3}\right)$ : 0

ANAL YTICAL COMMENT: No Fibers Detected.

SAMPLE NO: NP 10

SAMPLE DATE: 04/21/88

CORE HOLE: AC-2

LOCATION: On face, between collar (5) and DCT.

RUN TIME (m): 282

MASS $\left(\mu \mathrm{g} / \mathrm{m}^{3}\right): 5.884412$

AIR VOL $\left(\mathrm{m}^{3}\right): 0.1$

FIBERS COUNTED 100 Optical Fields (fibers): 0 FIBER CONC. $\left(\mathrm{f} / \mathrm{cm}^{3}\right)$ :

ANAL YTICAL COMMENTS: No Fibers Detected.

SAMPLE NO: NP 59

SAMPLE DATE: $03 / 30 / 88$

CORE HOLE: AC-1

LOCATION: Left wall (approximately $8 \mathrm{ft}$

from face) even with Drill.

RIN TIME (m): 30

MASS $\left(\mu \mathrm{g} / \mathrm{m}^{3}\right): 2.762536$

AIR VOL $\left(\mathrm{m}^{3}\right): 0.061$

FIBERS COUNTED/100 Optical Fields (fibers): 0 FIBER CONC. $\left(\mathrm{f} / \mathrm{c} \mathrm{m}^{3}\right): 0$

ANALYTICAL COMMENTS: No Fibers Detected. 
SAMPLE NO: NP 55

SAMPLE DATE; 03/30/88

CORE HOLE: AC-1

LOCATION: On wall of Extensiometer/

Demonstration curve.

RUN TIME (m): 68.5

MASS $\left(\mu \mathrm{g} / \mathrm{m}^{3}\right): 2.39308$

AIR VOL $\left(\mathrm{m}^{3}\right): 1.266$

FIBERS COUNTED/100 Optical Fields (fibers): 0 FIBER CONC. $\left(\mathrm{f} / \mathrm{cm}^{3}\right): 0$

ANAL YTICAL COMMENTS: No Fibers Detected.

SAMPLE NO: NP 47B

SAMPLE DATE: 04/12/8

CORE HOLE: AC-2

LOCATION: Blank sent with set for PIXE analysis.

RUN TIME (m): 60.2

MASS $\left(\mu \mathrm{g} / \mathrm{m}^{3}\right): 2.181741$

AIR VOL $\left(\mathrm{m}^{3}\right): 0.06$

FIBERS COUNTED/100 Optical Fields (fibers): 0 FIBER CONC $\left(\mathrm{f} / \mathrm{cm}^{3}\right)$ : 0

ANALYTICAL COMMENTS: No Fibers Detected.

SAMPLE NO: NP4

SAMPLE DATE: 04/20/88

CORE HOLE: AC-2

LOCATION: On DCT.

RUN TIME (m): 152

MASS $\left(\mu \mathrm{g} / \mathrm{m}^{3}\right): .887699$

AIR VOL $\left(\mathrm{m}^{3}\right): 0.294$

FIBERS COUNTED/100 Optical Fields (fibers): 0 FIBER CONC. $\left(\mathrm{f} / \mathrm{cm}^{3}\right): 0$

ANAL YTICAL COMMENTS: No Fibers Detected.
SAMPLE NO: NP 5

SAMPLE DATE: 04/19/88

CORE HOLE: AC-2

LOCATION: On DCT front.

RUN TIME (m): 60

MASS $\left(\mu \mathrm{g} / \mathrm{m}^{3} \mathrm{~g} / \mathrm{m}^{3}\right): 4.517024$

AIR VOL $\left(\mathrm{m}^{3}\right): 0.105$

FIBERS COUN, ED/100 Optical Fields (fibers): 0 FIBER CONC $\left(\mathrm{f} / \mathrm{cm}^{3}\right): 0$

ANALYTICAL COMMENTS: No Fibers Detected.

SAMPLE NO: NP 14

SAMPLE DATE: 04/21/88

CORE HOLE: AC-2

LOCATION: On DCT front.

RUN TIME (m): 293.4

MASS $\left(\mu \mathrm{g} / \mathrm{m}^{3}\right): 10.50574$

AIR VOL $\left(\mathrm{m}^{3}\right): 0.44$

FIBERS COUNTED/100 Optical Fields (fibers): 0 FIBEP. CONC. $\left(\mathrm{f} / \mathrm{cm}^{3}\right): 0$

ANAL YTICAL COMMENTS: No Fibers Detected.

SAMPLE NO: NP 52

SAMPLE DATE: 03/29/88

CORE HOLE: AC-1

LOCATION: Personal sample on investigator.

RUN TIME (m): 60

MASS $\left(\mu \mathrm{g} / \mathrm{m}^{3}\right): 0.547707$

AIR VOL $\left(\mathrm{m}^{3}\right): 0.126$

FIBERS COUNTED/100 Optical Fields (fil: rs): 0

FIBER CONC. $\left(\mathrm{f} / \mathrm{cm}^{3}\right): 0$

ANALYTICAL COMMENTS: No Fibers Detected. 
SAMPLE NO: NP 49B

SAMPLE DATE: 04/08/88

CORE HOLE: AC-1

LOCATION: BLIND BLANK - NP sample set.

RUN TIME (m): 50

MASS $\left(\mu \mathrm{g} / \mathrm{m}^{3}\right): 0$

AIR VOL $\left(\mathrm{m}^{3}\right): 0.106$

FIBERS COUNTED/100 Optical Fields (fibers): 0 FIBER CONC. $\left(\mathrm{f} / \mathrm{cm}^{3}\right): 0$

ANAL YTICAL COMMENTS: No Fibers Detected.

SAMPLE NO: NP 71

SAMPLE DATE: 03/22/88

CORE HOLE: AC-1

LOCATION: BACKGROUND-Demonstration Drift. RUN TIME (m): 100

MASS $\left(\mu \mathrm{g} / \mathrm{m}^{3}\right): 0$

AIR VOL $\left(\mathrm{m}^{3}\right): 0.2294$

FIBERS COUNTED/100 Optical Fields (fibers): . 0 FIBER CONC $\left(\mathrm{f} / \mathrm{cm}^{3}\right): 0$

ANALYTICAL COMMENTS: No Fibers Detected.

SAMPLE NO: NP 72

SAMPLE DATE: 03/23/88

CORE HOLE: AC-1

LOCATION: ACI location, left side Demonstration

Drift.

RUN TIME (m): 81

$\operatorname{MASS}\left(\mu \mathrm{g} / \mathrm{m}^{3}\right): 0$

AIR VOL $\left(\mathrm{m}^{3}\right)$ : 0.1861

FIBERS COUNTED/100 Optical Fields (fibers): 0 FIBER CONC. $\left(\mathrm{f} / \mathrm{cm}^{3}\right): 0$

ANALYTICAL COMMENTS: No Fibers Detected.
SAMPLE NO: NP 73

SAMPLE DATE: 03/23/88

CORE HOLE: AC-1

LOCATION: Right ACI location, Demonstration

Drift.

RUN TIME (m): 72

MASS $\left(\mu \mathrm{g} / \mathrm{m}^{3}\right): 0$

AIR VOL (m): 0.1317

FIBERS COUNTED/100 Optical Fields (fibers): 0 FIBER CONC. $\left(\mathrm{f} / \mathrm{cm}^{3}\right): 0$

ANALYTICAL COMMENTS: No Fibers Detected.

SAMPLE NO: NP 74

SAMPLE DATE: $03 / 25 / 88$

CORE HOLE: AC-1

LOCATION: Personal sample on investigator.

RUN TIME (m): 64.7

MASS $\left(\mu \mathrm{g} / \mathrm{m}^{3}\right): 0$

AIR VOL $\left(\mathrm{m}^{3}\right)$ : 0.1148

FIBERS COUNTED/100 Optical Fields (fibers): 0 FIBER CONC. $\left(\mathrm{f} / \mathrm{cm}^{3}\right): 0$

ANAL YTICAL COMMENTS: No Fibers Detected.

SAMPLE NO: NP 75

SAMPLE DATE: 03/25/88

CORE HOLE: AC-1

LOCATION: Personal sample on investigator.

RUN TIME (m): 68.7

MASS $\left(\mu \mathrm{g} / \mathrm{m}^{3}\right): 0$

AIR VOL $\left(\mathrm{m}^{3}\right): 0.1514$

FIBERS COUNTED/100 Optical Fields (fibers): 0 FIBER CONC. $\left(\mathrm{f} / \mathrm{cm}^{3}\right): 0$

ANAL YTICAL COMMENTS: No Fibers Detected 
SAMPLE NO: NP 48B

SAMPLE DATE: 04/08/88

CORE HOLE: AC-1

LOCATION: BLIND BLANK

RUN TIME (m): 45

MASS $\left(\mu g / \mathrm{m}^{3}\right): 0$

AIR VOL $\left(\mathrm{m}^{3}\right): 0.0923$

FIBERS COUNTED/100 Optical Fields (fibers): 0 FIBER CONC. $\left(\mathrm{f} / \mathrm{cm}^{3}\right): 0$

ANALYTICAL COMMENTS: No Fibers Detected.

SAMPLE NO: NP 51

SAMPLE DATE: 03/30/88

CORE HOLE: AC-1

LOCATION: ON DCT.

RUN TIME (m): 15

MASS $\left(\mu \mathrm{g} / \mathrm{m}^{3}\right): 0$

AIR VOL $\left(\mathrm{m}^{3}\right)$ : 0.0305

FIBERS COUNTED/100 Optical Fields (fibers): 0 FIBER CONC. $\left(\mathrm{f} / \mathrm{cm}^{3}\right): 0$

ANALYTICAL COMMENTS: No Fibers Detected.

SAMPLE NO: NP 53

SAMPLE DATE: 03/30/88

CORE HOLE: AC-1

LOCATION: Right side Demonstration Drift, even with drill.

RUNTIME (m): 30

MASS $\left(\mu \mathrm{g} / \mathrm{m}^{3}\right): 0$

AIR VOL $\left(\mathrm{m}^{3}\right): 0.061$

FIBERS COUNTED/100 Optical Fields (fibers): 0 FIBER CONC. $\left(\mathrm{f} / \mathrm{cm}^{3}\right): 0$

ANAL YTICAL COMMENTS: No Fibers Detected.
SAMPLE NO: NP 54

SAMPLE DATE: 03/30/88

CORE HOLE: AC-1

LOCATION: Personal sample on investigator.

RUN TIME (m): 50

MASS $\left(\mu \mathrm{g} / \mathrm{m}^{3}\right): 0$

AIR VOL $\left(\mathrm{m}^{3}\right): 0.0968$

FIBERS COUNTED/100 Optical Fields (fibers): 0 FIBER CONC. $\left(\mathrm{f} / \mathrm{cm}^{3}\right): 0$

ANAL YTICAL COMMENTS: No Fibers Detected.

SAMPLE NO. NP 57

SAMPLE DATE: 03/30/88

CORE HOLE: AC-1

LOCATION: On DCT.

RUN TIME (m): 30

MASS $\left(\mu \mathrm{g} / \mathrm{m}^{3}\right) 0$

AIR VOL (m $\left.{ }^{3}\right): 0.061$

FIBERS COUNTED/100 Optical Fields (fibers): 0 FIBER CONC. $\left(\mathrm{f} / \mathrm{cm}^{3}\right): 0$

ANALYTICAL COMMENTS: No Fibers Detected.

SAMPLE NO: NP 63

SAMPLE DATE: 03/30/88

CORE HOLE: AC-1

LOCATION: ON DCT.

RUN TIME (m): 15

MASS $\left(\mu \mathrm{g} / \mathrm{m}^{3}\right): 0$

AIR VOL $\left(\mathrm{m}^{3}\right): 0.0305$

FIBERS COUNTED/100 Optical Fields (fibers): 0 FIBER CONC. $\left(\mathrm{f} / \mathrm{cm}^{3}\right): 0$

ANALYTICAL COMMENTS: No Fibers Detected. 
SAMPLE NO: NP 68

SAMPLE DATE: 03/30/88

CORE HOLE: AC-1

LOCATION: On wall of Extensiometer

Demonstration Curve.

RUN TIME (m): 30

MASS $\left(\mu \mathrm{g} / \mathrm{m}^{3}\right): 0$

AIR VOL $\left(\mathrm{m}^{3}\right): 0.055$

FIBERS COUNTED/100 Optical Fields (fibers): 0 FIBER CONC. $\left(\mathrm{f} / \mathrm{cm}^{3}\right): 0$

ANALYTICAL COMMENTS: No Fibers Detected.

SAMPLE NO: NP 50

SAMPLE DATE: 04/13/88

CORE HOLE: AC-2

LOCATION: BACKGROUND.

RUN TIME (m): 720

MASS $\left(\mu \mathrm{g} / \mathrm{m}^{3}\right): 0$

AIR VOL $\left(\mathrm{m}^{3}\right): 1.4508$

FIBERS COUNTED/100 Optical Fields (fibers):

FIBER CONC. $\left(\mathrm{f} / \mathrm{cm}^{3}\right): 0$

ANAL YTICAL COMMENTS: No Fibers Detected.

SAMPLE NO: NP 58B

SAMPLE DATE: 04/26/88

CORE HOLE: AC-1

LOCATION: BLANK - NP sample set.

RUN TIME (m): 0

MASS $\left(\mu \mathrm{g} / \mathrm{m}^{3}\right): 0$

AIR VOL $\left(\mathrm{m}^{3}\right): 0$

FIBERS COUNTED/100 Optical Fields (fibers): 0 FIBER CONC. $\left(\mathrm{f} / \mathrm{cm}^{3}\right): 0$

ANALYTICAL COMMENTS: No Fibers Detected.
SAMPLE NO: NP 64

SAMPLE DATE: 04/14/88

CORE HOLE: AC-2

LOCATION: On water box.

RUN TIME (m): 70.7

MASS $\left(\mu \mathrm{g} / \mathrm{m}^{3}\right): 0$

AIR VOL $\left(\mathrm{m}^{3}\right)$ : 0.1395

FIBERS COUNTED/100 Optical Fields (fibers): 0 FIBER CONC. $\left(\mathrm{f} / \mathrm{cm}^{3}\right): 0$

ANALYTICAL COMMENTS: No Fibers Detected.

SAMPLE NO: NP7

SAMPLE DATE: 04/19/88

CORE HOLE: AC-2

LOCATION: On water box.

RUN TIME (m): 60

MASS $\left(\mu \mathrm{g} / \mathrm{m}^{3}\right): 0$

AIR VOL $\left(\mathrm{m}^{3}\right): 0.1228$

FIBERS COUNTED/100 Optical Fields (fibers): 0 FIBER CONC. $\left(\mathrm{f} / \mathrm{cm}^{3}\right): 0$

ANAL YTICAL COMMENTS: No Fibers Detected.

SAMPLE NO: NP6

SAMPLE DATE: 04/19/88

CORE HOLE: AC-2

LOCATION: On water box.

RUN TIME (m): 30

MASS $\left(\mu \mathrm{g} / \mathrm{m}^{3}\right): 0$

AIR VOL ( $\left.\mathrm{m}^{3}\right)$ : 0.0614

FIBERS COUNTED/100 Optical Fields (fibers): 0 FIBER CONC. $\left(\mathrm{f} / \mathrm{cm}^{3}\right): 0$

ANALYTICAL COMMENTS: No Fibers Detected. 
SAMPLE NO: NP9

SAMPLE DATE: 04/19/88

CORE HOLE: AC-2

LOCATION: On front of DCT.

RUN TIME (m): 30

MASS $\left(\mu \mathrm{g} / \mathrm{m}^{3}\right): 0$

AIR VOL $\left(\mathrm{m}^{3}\right)$ : 0.0526

FIBERS COUNTED/100 Optical Fields (fibers): 0 FIBER CONC. $\left(\mathrm{f} / \mathrm{cm}^{3}\right): 0$

ANALYTICAL COMMENTS: No Fibers Detected.

SAMPLE NO: NP 12

SAMPLE DATE: 04/19/88

CORE HOLE: AC-2

LOCATION: On water box.

RUN TIME (m): 30

MASS $\left(\mu \mathrm{g} / \mathrm{m}^{3}\right): 0$

AIR VOL $\left(\mathrm{m}^{3}\right): 0.0614$

FIBERS COUNTED/100 Optical Fields (fibers): 0 FIBER CONC. $\left(\mathrm{f} / \mathrm{cm}^{3}\right): 0$

ANALYTICAL COMMENTS: No Fibers Detected.

SAMPLE NO: NP 16

SAMPLE DATE: 04/20/88

CORE HOLE: AC-2

LOCATION: Personal sample on investigator.

RUN TIME (m): 63

MASS $\left(\mu \mathrm{g} / \mathrm{m}^{3}\right): 0$

AIR VOL $\left(\mathrm{m}^{3}\right): 0.1316$

FIBERS COUNTED/100 Optical Fields (fibers): 0 FIBER. CONC. $\left(\mathrm{f} / \mathrm{cm}^{3}\right): 0$

ANALYTICAL COMMENTS: No Fibers Detected.
SAMPLE NO: NP 17

SAMPLE DATE: 04/19/88

CORE HOLE: AC-2

LOCATION: On water box.

RUN TIME (m): 30

MASS $\left(\mu \mathrm{g} / \mathrm{m}^{3}\right): 0$

AIR VOL $\left(\mathrm{m}^{3}\right): 0.0526$

FIBERS COUNTED/100 Optical Fields (fibers): 0 FIBER CONC. $\left(\mathrm{f} / \mathrm{cm}^{3}\right): 0$

ANAJ ? TICAL COMMENTS: No Fibers Detected.

SAMPLE NO: NP 19

SAMPLE DATE: 04/19/88

CORE HOLE: AC-2

LOCATION: On water box.

RUN TIME (m): 30

MASS $\left(\mu \mathrm{g} / \mathrm{m}^{3}\right): 0$

AIR VOL $\left(\mathrm{m}^{3}\right): 0.0584$

FIBERS COUNTED/100 Optical Fields (fibers): 0 FIBER CONC. $\left(\mathrm{f} / \mathrm{cm}^{3}\right): 0$

ANAL YTICAL COMMENTS: No Fibers Detected

SAMPLE NO: NP 24

SAMPLE DATE: $04 / 19 / 88$

CORE HOLE: AC-2

LOCATION: Back wall.

RUN TIME (m): 101

MASS $\left(\mu \mathrm{g} / \mathrm{m}^{3}\right): 0$

AIR VOL $\left(\mathrm{m}^{3}\right): 0.2138$

FIBERS COUNTED/100 Optical Fields (fibers): 0 FIBER CONC. $\left(\mathrm{f} / \mathrm{cm}^{3}\right): 0$

ANAL YTICAL COMMENTS: No Fibers Detected. 
SAMPLE NO: NP 26

SAMPLE DATE: 04/20/88

CORE HOLE: AC-2

LOCATION: On water box.

RUN TIME (m): 60

MASS $\left(\mu \mathrm{g} / \mathrm{m}^{3}\right): 0$

AIR VOL (m $\left.\mathrm{m}^{3}\right): 0.1023$

FIBERS COUNTED/100 Optical Fields (fibers): 0 FIBER CONC. $\left(\mathrm{f} / \mathrm{cm}^{3}\right): 0$

ANAL YTICAL COMMENTS: No Fibers Detected.

SAMPLE NO: NP 28

SAMPLE DATE: 04/20/88

CORE HOLE: AC-2

LOCATION: On water box.

RUN TIME (m): 60

MASS $\left(\mu \mathrm{g} / \mathrm{m}^{3}\right): 0$

AIR VOL $\left(\mathrm{m}^{3}\right): 0.1023$

FIBERS COUNTED/100 Optical Fields (fibers): 0 FIBER CONC. $\left(\mathrm{f} / \mathrm{cm}^{3}\right)$ : 0

ANALYTICAL COMMENTS: No Fibers Detected.

SAMPLE NO: NP 29

SAMPLE DATE: 04/20/88

CORE HOLE: AC-2

LOCATION: At DCT.

RUN TIME (m): 102

MASS $\left(\mu \mathrm{g} / \mathrm{m}^{3}\right): 0$

AIR VOL $\left(\mathrm{m}^{3}\right)$; 0.1963

FIBERS COUNTED/100 Optical Fields (fibers): 0 FIBER CONC. $\left(\mathrm{f} / \mathrm{cm}^{3}\right): 0$

ANALYTICAL COMMENTS: No Fibers Detected.
SAMPLE NO: NP 33B

SAMPLE DATE: 04/26/88

CORE HOLE: AC-2

LOCATION: BLANK - NP sample set.

RUN TIME (m): 0

MASS $\left(\mu g / \mathrm{m}^{3}\right): 0$

AIR VOL $\left(\mathrm{m}^{3}\right): 0$

FIBERS COUNTED/100 Optical Fields (fibers): 0 FIBER CONC. $\left(\mathrm{f} / \mathrm{cm}^{3}\right): 0$

ANALYTICAL COMMENTS: No Fibers Detected.

SAMPLE NO: NP 34

SAMPLE DATE: 04/19/88

CORE HOLE: AC-2

LOCATION: Wall behind DCT,

RUN TIME (m): 45

MASS $\left(\mu \mathrm{g} / \mathrm{m}^{3}\right): 0$

AIR VOL $\left(\mathrm{m}^{3}\right)$ : 0.0877

FIBERS COUNTED/100 Optical Fields (fibers): 0 FIBER CONC. $\left(\mathrm{f} / \mathrm{cm}^{3}\right): 0$

ANALYTICAL COMMENTS: No Fibers Detected.

SAMPLE NO: NP 35

SAMPLE DATE: $04 / 19 / 88$

CORE HOLE: AC-2

LOCATION: Wall behind DCT.

RUN TIME (m): 34

MASS $\left(\mu \mathrm{g} / \mathrm{m}^{3}\right): 0$

AIR VOL $\left(\mathrm{m}^{3}\right)$ : 0.0662

FIBERS COUNTED/100 Optical Fields (fibers): 0 FIBER CONC. $\left(\mathrm{f} / \mathrm{cm}^{3}\right): 0$

ANALYTICAL COMMENTS: No Fibers Detected. 
SAMPLE NO: NP 40B

SAMPLE DATE: 04/26/88

CORE HOLE: AC-2

LOCATION: BLANK - NP sample set.

RUN TIME (m): 0

MASS $\left(\mu \mathrm{g} / \mathrm{m}^{3}\right): 0$

AIR VOL $\left(\mathrm{m}^{3}\right): 0$

FIBERS COUNTED/100 Optical Fields (fibers): 0 FIBER CONC. $\left(\mathrm{f} / \mathrm{cm}^{3}\right): 0$

ANAL YTICAL COMMENTS: No Fibers Detected.

SAMPLE NO: NP 69

SAMPLE DATE: 03/30/88

CORE HOLE: AC-2

LOCATION: On DCT (removed from set/ contaminated).

RUN TIME (m): 60

MASS $\left(\mu \mathrm{g} / \mathrm{m}_{3}^{3}\right): 0$

AIR VOL $\left(\mathrm{m}^{3}\right): 0.1052$

FIBERS COUNTED/100 Optical Fields (fibers) 0 FIBER CONC. $\left(\mathrm{f} / \mathrm{cm}^{3}\right): 0$

ANAL YTICAL COMMENTS: No Fibers Detected.

SAMPLE NO: NP 61

SAMPLE DATE: 04/19/88

CORE HOLE: AC-2

LOCATION: Between DCT and drill collar.

RUN TIME (m): 120

MASS $\left(\mu \mathrm{g} / \mathrm{m}^{3}\right): 0$

AIR VOL $\left(\mathrm{m}^{3}\right)$ : 0.242

FIBERS COUNTED/100 Optical Fields (fibers): 0 FIBER CONC. $\left(\mathrm{f} / \mathrm{cm}^{3}\right): 0$

ANAL YTICAL COMMENTS: No Fibers Detected.
SAMPLE NO: NP 62

SAMPLE DATE: 04/18/88

CORE HOLE: AC-2

LOCATION: On water box.

RUN TIME (m): 30

MASS $\left(\mu \mathrm{g} / \mathrm{m}^{3}\right): 0$

AIR VOL $\left(\mathrm{m}^{3}\right): 0.0604$

FIBERS COUNTED/100 Optical Fields (fibers): 0 FIBER CONC. $\left(\mathrm{f} / \mathrm{cm}^{3}\right): 0$

ANAL YTICAL COMMENTS: No Fibers Detected.

SAMPLE NO: NP 66

SAMPLE DATE: 04/19/88

CORE HOLE: $A C-2$

LOCATION: On DCT.

RUN TIME (m): 27

MASS $\left(\mu \mathrm{g} / \mathrm{m}^{3}\right): 0$

AIR VOL $\left(\mathrm{m}^{3}\right)$ : 0.0474

FIBERS COUNTED/100 Optical Fields (fibers): 0 FIBER CONC. $\left(\mathrm{f} / \mathrm{cm}^{3}\right)$ : 0

ANAL YTICAL COMMENTS: No Fibers Detected.

SAMPLE NO: NP 67

SAMPLE DATE: 04/18/88

CORE HOLE: AC-2

LOCATION: On water box.

RUN TIME (m): 30

MASS $\left(\mu g / \mathrm{m}^{3}\right): 0$

AIR VOL $\left(\mathrm{m}^{3}\right)$ : 0.0604

FIBERS COUNTED/100 Optical Fields (fibers): 0 FIBER CONC. $\left(f / \mathrm{cm}^{3}\right): 0$

ANALYTICAL COMMENTS: No Fibers Detected. 
SAMPLE NO: NP 1

SAMPLE DATE: 04/14/88

CORE HOLE: AC-2

LOCATION: On DCT.

RUN TIME (m): 377

MASS $\left(\mu \mathrm{g} / \mathrm{m}^{3}\right): 0.000135$

AIR VOL $\left(\mathrm{m}^{3}\right): 0$

FIBERS COUNTED/100 Optical Fields (fibers): 0 FIBER CONC. $\left(\mathrm{f} / \mathrm{cm}^{3}\right): 0$

ANAL YTICAL COMMENTS: No Fibers Detected.

SAMPLE NO: NP 2

SAMPLE DATE: 04/14/88

CORE HOLE: AC-2

LOCATION: On DCT.

RUN TIME (m): 362.9

MASS $\left(\mu \mathrm{g} / \mathrm{m}^{3}\right): 0.000026$

AIR VOL $\left(\mathrm{m}^{3}\right): 0.82$

FIBERS COUNTED/100 Optical Fields (fibers): 0 FIBER CONC. $\left(\mathrm{f} / \mathrm{cm}^{3}\right): 0$

ANALYTICAL COMMENTS: No Fibers Detected.

BULK SAMPLE FIBER ANALYSIS BY SEM/EDX

SAMPLE ID: AC-1/R-7 \#2

SAMPLE DATE: 03/29/88

CORE HOLE: AC-1

LOCATION: BULK SAMPLE \#2/DCT BAG RUn 7.

FIBERS COUNTED/100 Optical Fields (fibers): 0

FIBER CONC. $\left(\mathrm{f} / \mathrm{cm}^{3}\right): 0$

ANAL YTICAL COMMENTS: No Fibers Detected.

SAMPLE ID.: AC-2/R 8-12 \#2

SAMPLE DATE: 04/13/88

CORE HOLE: AC-2

LOCATION: BULK SAMPLE \#2/DCT BAG

Runs 8-12.

FIBERS COUNTED/100 Optical Fields (fibers): 0 FIBER CONC. $\left(\mathrm{f} / \mathrm{cm}^{3}\right)$ : 0

ANALYTICAL, COMMENTS: No Fibers Detected. 

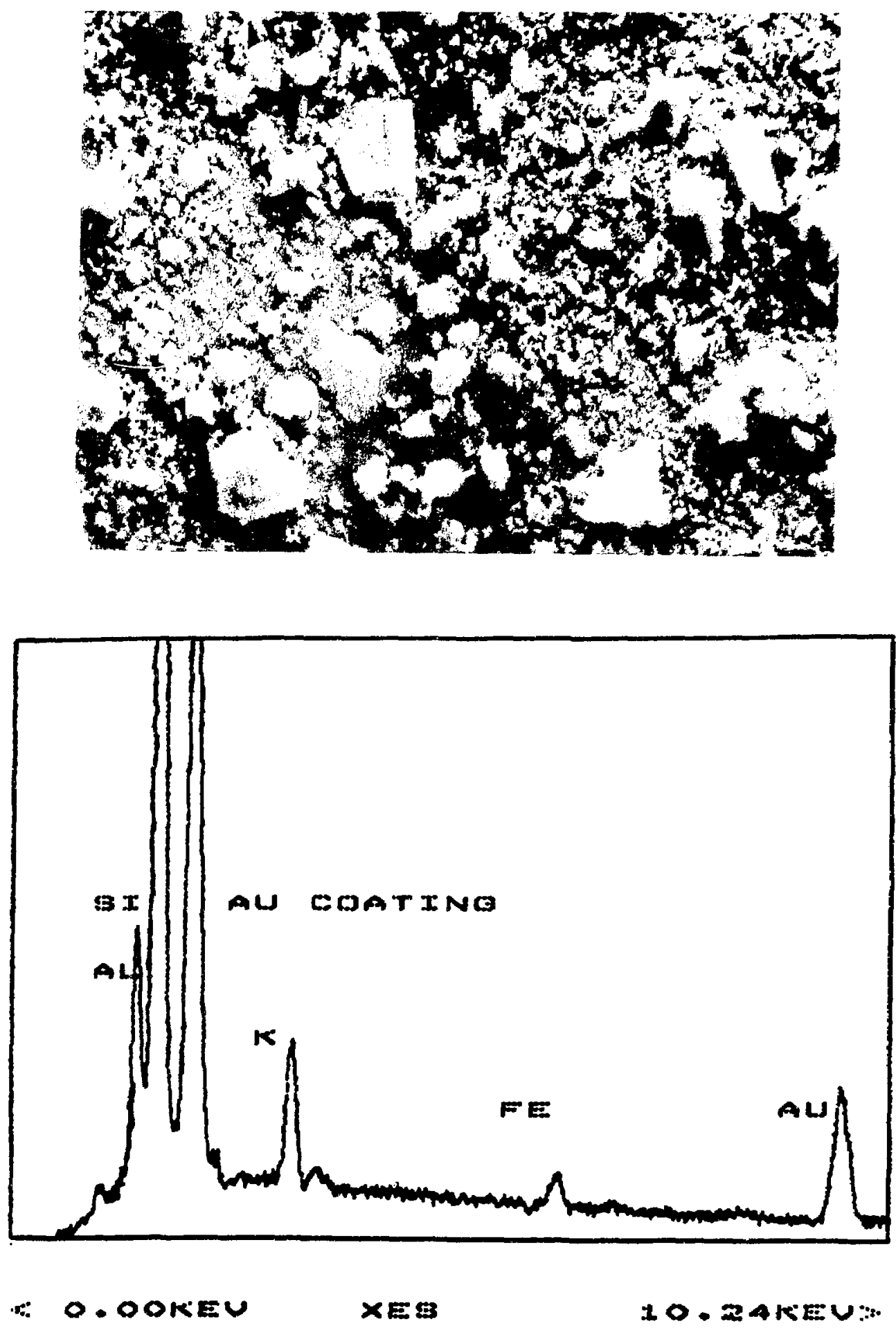

Figure D5-1. SEM Photomicrograph (1000x) and EDX Spectra for BulkAC-I Run "7 (2). 

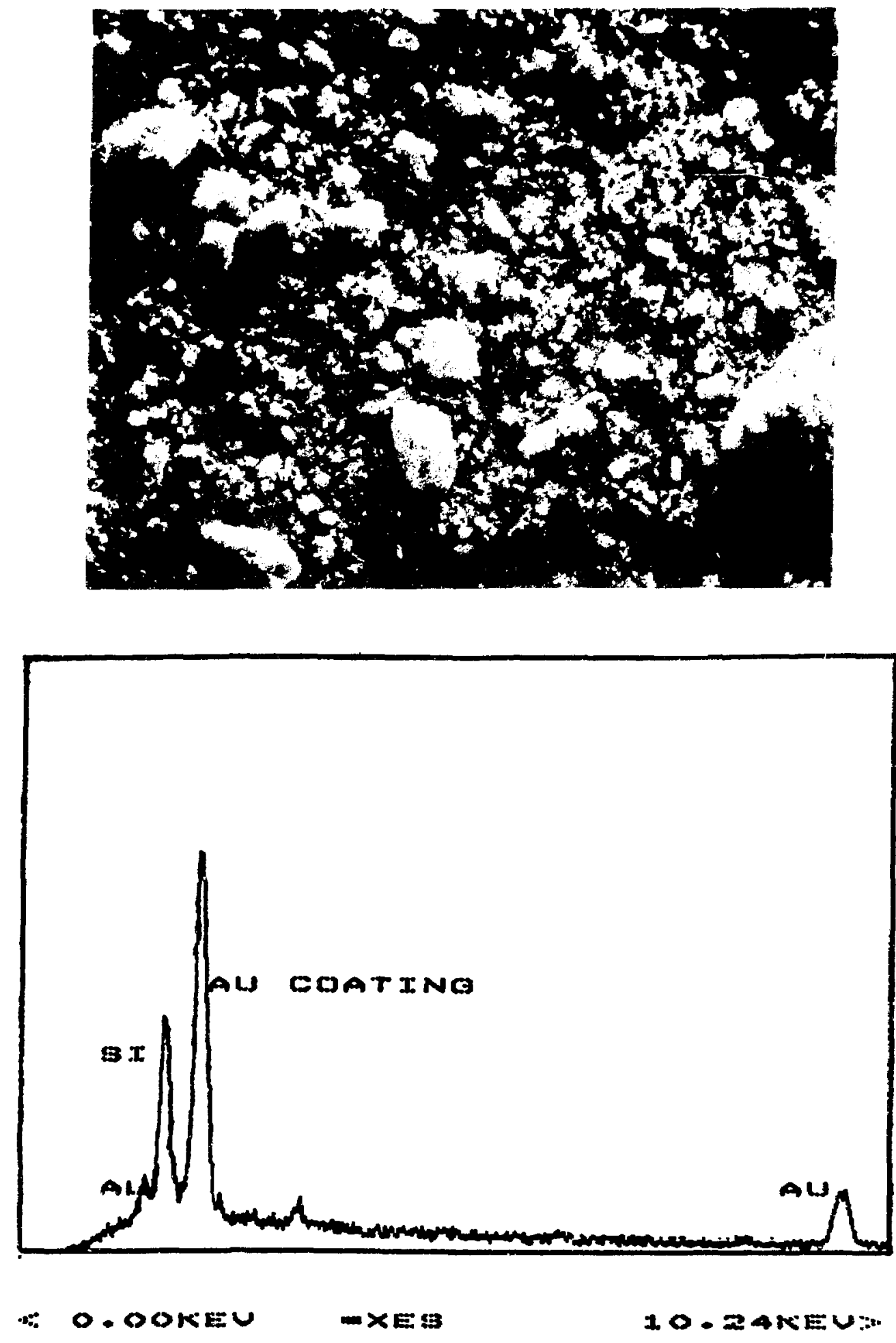

Fizure D5-2. SEM Phoromicrogreph (2000x) and EDX Spectra for BulkAC-2 Run HS (2). 
APPENDIX D-6

CASCADE IMPACTOR DATA

DM FILTER SET: DM-01A

SAMPLE DATE: 03/29/88

IMPACTOR ID: ACI-099

CORE HOLE: AC-1

LOCATION: Right wall, approximately $12 \mathrm{ft}$ from Demonstration Drift face

RUN TIME (min): 248

$\begin{array}{lll}\text { PRE-SEPARATOR } & 0.000735 & 0.735 \\ \text { STAGE 0 } & 0.00067 & 0.67 \\ \text { STAGE 1 } & 0.001043 & 1.043 \\ \text { STAGE 2 } & 0.000681 & 0.681 \\ \text { STAGE 3 } & 0.001364 & 1.364 \\ \text { STAGE 4 } & 0.001444 & 1.444 \\ \text { STAGE 5 } & 0.001211 & 1.211 \\ \text { STAGE 6 } & 0.000839 & 0.839 \\ \text { STAGE 7 } & 0.000617 & 0.617 \\ \text { FINAL } & 0.001094 & 1.094\end{array}$

TOTAL WEIGHT GAIN (g); 0.009698 (mg): 9.698

MASS MEDIAN AERODYNAMIC DIAMETER $(\mu \mathrm{m}): 1.866$

STANDARD DEVIATION: 3.67

IMPACTOR CONCENTRATION $\left(\mathrm{mg} / \mathrm{m}^{3}\right): 1.28$

DM FILTER SET: DM-02A

SAMPLE DATE: $03 / 29 / 88$

IMPACTOR ID: ACl-934

CORE HOLE: AC-1

LOCATION: Left wall, approximately $12 \mathrm{ft}$ from Demonstration Drift face

RUN TIME (min): 248

$\begin{array}{lll}\text { PRE-SEPARATOR } & 0.000322 & 0.322 \\ \text { STAGE 0 } & 0.000551 & 0.551 \\ \text { STAGE 1 } & 0.000708 & 0.708 \\ \text { STAGE 2 } & 0.000387 & 0.387 \\ \text { STAGE 3 } & 0.000473 & 0.473 \\ \text { STAGE 4 } & 0.000406 & 0.406 \\ \text { STAGE 5 } & 0.000377 & 0.377 \\ \text { STAGE 6 } & 0.000289 & 0.289 \\ \text { STAGE 7 } & 0.000373 & 0.373 \\ \text { FINAL } & 0.001281 & 1.281\end{array}$

TOTAL WEIGHT GAIN (g): 0.005167 (mg): 5.167

MASS MEDIAN AERODYNAMIC DIAMETER $(\mu \mathrm{m}): 1.52$

STANDARD DEVIATION: 6.73

IMPACTOR CONCENTRATION $\left(\mathrm{mg}^{\mathrm{m}} \mathrm{m}^{3}\right): 0.69$ 
MMPACTI R ID: ACI-931

CORE HOLE: AC-1

LOCATION: (Negative weights for all but final stage, unusable data)

RUN TIME (min): 120

$\begin{array}{lll}\text { PRE-SEPARATOR } & 0 & 0 \\ \text { STAGE 0 } & 0 & 0 \\ \text { STAGE 1 } & 0 & 0 \\ \text { STAGE 2 } & 0 & 0 \\ \text { STAGE 3 } & 0 & 0 \\ \text { STAGE 4 } & 0 & 0 \\ \text { STAGE 5 } & 0 & 0 \\ \text { STAGE 6 } & 0 & 0 \\ \text { STAGE 7 } & 0 & 0 \\ \text { FINAL } & 0.0000391 & 0.391\end{array}$

TOTAL WEIGHT GAIN (g): 0 (mg): 0

MASS MEDIAN AERODYNAMIC DIAMETER $(\mu \mathrm{m})$ :

STANDARD DEVIATION: 0

IMPACTOR CONCENTRATION $\left(\mathrm{mg}^{3} \mathrm{~m}^{3}\right)$ :

DM FILTER SET: DM-04A

SAMPLE DATE: $03 / 25 / 88$

IMPACTOR ID: ACI- 899

CORE HOLE: AC-1

LOCATION: Left impactor pusition (12 ft from Demonstration Drift face)

RUN TIME (min): 75

$\begin{array}{lll}\text { PRE-SEPARATOR } & 0.000932 & 0.932 \\ \text { STAGE 0 } & 0.001045 & 1.045 \\ \text { STAGE 1 } & 0.00127 & 1.27 \\ \text { STAGE 2 } & 0.00054 & 0.54 \\ \text { STAGE 3 } & 0.001115 & 1.115 \\ \text { STAGE 4 } & 0.001024 & 1.024 \\ \text { STAGE 5 } & 0.000961 & 0.961 \\ \text { STAGE 6 } & 0.000069 & 0.069 \\ \text { STAGE 7 } & -0.00012 & -0.119 \\ \text { FINAL } & 0.000196 & 0.196\end{array}$

TOTAL WEIGHT GAIN (g): 0.007033 (mg): 7.033

MASS MEDIAN AERODYNAMIC DIAMETER $(\mu \mathrm{m}): 3.834$

STANDARD DEVIATION: 3.07

IMPACTOR CONCENTRATION $\left(\mathrm{mg} / \mathrm{m}^{3}\right): 2.99$ 
IMPACTOR ID: ACI-1001

CORE HOLE: AC-1

LOCATION: Right-side Demonstration Drifh, approximately $12 \mathrm{ft}$ from face

RUN TIME (min): 95

$\begin{array}{lll}\text { PRE-SEPARATOR } & 0.000004 & 0.004 \\ \text { STAGE 0 } & 0.000773 & 0.773 \\ \text { STAGE 1 } & 0.000549 & 0.549 \\ \text { STAGE 2 } & 0.000725 & 0.725 \\ \text { STAGE 3 } & 0.002333 & 2.333 \\ \text { STAGE 4 } & 0.001998 & 1.998 \\ \text { STAGE 5 } & 0.001484 & 1.484 \\ \text { STAGE 6 } & 0.000897 & 0.897 \\ \text { STAGE 7 } & 0.000238 & 0.238 \\ \text { FINAL } & 0.000493 & 0.493\end{array}$

TOTAL WEIGHT GAIN (g): 0.009494 (mg): 9.494

MASS MEDIAN AERODYNAMIC DIAMETER $(\mu \mathrm{m}): 2.481$

STANDARD DEVIATION: 2.536

IMPACTOR CONCENTRATION $\left(\mathrm{mg} / \mathrm{m}^{3}\right): 3.53$

DM FILTER SET: DM-06A

SAMPLE DATE: 03/23/88

IMPACTOR ID: ACI-892

CORE HOLE: AC-1

LOCATION: Left-side Demonstration Drift, approximately $12 \mathrm{ft}$ from face

RUN TIME (min): 95

$\begin{array}{lll}\text { PRE-SEPARATOR } & 0.003085 & 3.085 \\ \text { STAGE 0 } & 0.00345 & 3.45 \\ \text { STAGE 1 } & 0.003826 & 3.826 \\ \text { STAGE 2 } & 0.00155 & 1.55 \\ \text { STAGE 3 } & 0.00366 & 3.66 \\ \text { STAGE 4 } & 0.00308 & 3.08 \\ \text { STAGE 5 } & 0.002391 & 2.391 \\ \text { STAGE 6 } & 0.000744 & 0.744 \\ \text { STAGE 7 } & 0.000283 & 0.283 \\ \text { FINAL } & 0.000656 & 0.656\end{array}$

TOTAL WEIGHT GAIN (g): 0.022725 (mg): 22.725

MASS MEDIAN AERODYNAMIC DIAMETER $(\mu \mathrm{m}): 3.847$

STANDARD DEVIATION: 2.93

IMPACTOR CONCENTRATION $\left(\mathrm{mg} / \mathrm{m}^{3}\right)$ : 7.31 
IMPACTOR ID: ACI-935

CORE HOLE: AC-1

LOCATION: BACKGROUND-Demonstration Drift (Muckers recently in main tunnel)

RUN TIME (min): 120

$\begin{array}{lll}\text { PRE-SEPARATOR } & 0.000337 & 0.337 \\ \text { STAGE 0 } & 0.000195 & 0.195 \\ \text { STAGE 1 } & 0.000192 & 0.192 \\ \text { STAGE 2 } & 0.000108 & 0.108 \\ \text { STAGE 3 } & 0.000174 & 0.174 \\ \text { STAGE 4 } & 0.000093 & 0.093 \\ \text { STAGE 5 } & 0.000051 & 0.051 \\ \text { STAGE 6 } & 0.000016 & 0.016 \\ \text { STAGE 7 } & 0.00008 & 0.08 \\ \text { FINAL } & 0.00043 & 0.43\end{array}$

TOTAL WEIGHT GAIN (g): 0.001676 (mg): 1.676

MASS MEDIAN AERODYNAMIC DIAMETER $(\mu \mathrm{m}): 1.65$

STANDARD DEVIATION: 8.32

IMPACTOR CONCENTRATION $\left(\mathrm{mg} / \mathrm{m}^{3}\right): 0.39$

DM FILTER SIT: DM-08A

SAMPLE DATE: 03/24/88

IMPACTOR ID: ACI-1002

CORE HOLE: AC-1

LOCATION: BACKGROUND-Demonstration Drift (Muckers recently in

main tunnel)

RUN TIME (min): 75

$\begin{array}{lll}\text { PRE-SEPARATOR } & 0 & 0 \\ \text { STAGE 0 } & 0.000498 & 0.498 \\ \text { STAGE 1 } & 0.000655 & 0.655 \\ \text { STAGE 2 } & 0.00035 & 0.35 \\ \text { STAGE 3 } & 0.000565 & 0.565 \\ \text { STAGE 4 } & 0.000582 & 0.582 \\ \text { STAGE 5 } & 0.000525 & 0.525 \\ \text { STAGE 6 } & 0.0001 & 0.1 \\ \text { STAGE 7 } & 0.000012 & 0.012 \\ \text { FINAL } & 0.000418 & 0.418\end{array}$

TOTAL WEIGHT GAIN (g): 0.003705 (mg): 3.705

MASS MEDIAN AERODYNAMIC DIAMETER $(\mu \mathrm{m}): 2.92$

STANDARD DEVIATION: 3.82

IMPACTOR CONCENTRATION $\left(\mathrm{mg}^{\mathrm{m}} \mathrm{m}^{3}\right)$ : 1.75 
IMPACTOR ID: ACI-892

CORE HOLE: AC-2

LOCATION: (Negative weights for stages 2-7, UNUSABLE DATA)

RUN TIME (min): 105

$\begin{array}{lll}\text { PRE-SEPARATOR } & 0.000515 & 0.515 \\ \text { STAGE 0 } & 0.000526 & 0.526 \\ \text { STAGE 1 } & 0.000236 & 0.236 \\ \text { STAGE 2 } & 0 & 0 \\ \text { STAGE 3 } & 0 & 0 \\ \text { STAGE 4 } & 0 & 0 \\ \text { STAGE 5 } & 0 & 0 \\ \text { STAGE 6 } & 0 & 0 \\ \text { STAGE ? } & 0 & 0 \\ \text { FINAL } & 0.000213 & 0.213\end{array}$

TOTAL WEIGHT GAIN (g): 0 (mg): 0

MASS MEDIAN AERODYNAMIC DIAMETER $(\mu \mathrm{m}): 0$

STANDARD DEVIATION: 0

IMPACTOR CONCENTRATION $\left(\mathrm{mg}^{3} \mathrm{~m}^{3}\right)$ : 0

DM FILTER SET: DM-10A

SAMPLE DATE: $04 / 14 / 88$

IMPACTOR ID: ACI-1002

CORE HOLE: AC-2

LOCATION: Center of Laser Drift, approximately $15 \mathrm{ft}$ from face

RUN TIME (min): 189

$\begin{array}{lll}\text { PRE-SEPARATOR } & 0.000603 & 0.603 \\ \text { STAGE 0 } & 0.000339 & 0.339 \\ \text { STAGE 1 } & 0.000332 & 0.332 \\ \text { STAGE 2 } & 0.000213 & 0.213 \\ \text { STAGE 3 } & 0.000181 & 0.181 \\ \text { STAGE 4 } & 0.00016 & 0.16 \\ \text { STAGE 5 } & 0.000215 & 0.215 \\ \text { STAGE 6 } & 0.000283 & 0.283 \\ \text { STAGE 7 } & 0.000261 & 0.261 \\ \text { FINAL } & 0.000845 & 0.845\end{array}$

TOTAL WEIGHT GAIN (g): 0.003432 (mg): 3.432

MASS MEDIAN AERODYNAMIC DIAMETER $(\mu \mathrm{m}): 1.14$

STANDARD DEVIATION: 8.41

IMPACTOR CONCENTRATION $\left(\mathrm{mg} / \mathrm{m}^{3}\right): .53$ 
IMPACTOR ID: ACI-899

CORE HOLE: AC-2

LOCATION: (Negative weights for stages 1-7, UNUS:iBLE DATA)

RUN TIME (min): 105

PRE-SEPARATOR
STAGE 0
STAGE 1
STAGE 2
STAGE 3
STAGE 4
STAGE 5
STAGE 6
STAGE 7
FINAL

$\begin{array}{ll}0.00025 & 0.25 \\ 0.000006 & 0.006 \\ 0 & 0 \\ 0 & 0 \\ 0 & 0 \\ 0 & 0 \\ 0 & 0 \\ 0 & 0 \\ 0 & 0 \\ 0.000247 & 0.247\end{array}$

TOTAL WEIGHT GAIN (g): 0 (mg): 0

MASS MEDIAN AERODYNAMIC DIAMETER $(\mu \mathrm{m}): 0$

STANDARD DEVIATION: 0

IMPACTOR CONCENTRATION $\left(\mathrm{mg}^{-\mathrm{m}^{3}}\right)$ : 0

IMPACTOR ID: ACI-1001

CORE HOLE: AC-2

LOCATION: Wall opposite core hole, approximately $20 \mathrm{ft}$ face between table and drill

RUN TIME (min): 256

$\begin{array}{lll}\text { PRE-SEPARATOR } & 0.000489 & 0.489 \\ \text { STAGE 0 } & 0.000522 & 0.522 \\ \text { STAGE I } & 0.000559 & 0.559 \\ \text { STAGE 2 } & 0.000427 & 0.427 \\ \text { STAGE 3 } & 0.000499 & 0.499 \\ \text { STAGE 4 } & 0.000463 & 0.463 \\ \text { STAGE 5 } & 0.000395 & 0.395 \\ \text { STAGE 6 } & 0.000363 & 0.363 \\ \text { STAGE 7 } & 0.000427 & 0.427 \\ \text { FINAL } & 0.001159 & 1.159\end{array}$

TOTAL WEIGHT GAIN (g): 0.005303 (mg): 5.303

MASS MEDIAN AERODYNAMIC DIAMETER $(\mu \mathrm{m}): 1.47$

STANDARD DEVIATION: 6.06

IMPACTOR CONCENTRATION $\left(\mathrm{mg} / \mathrm{m}^{3}\right): .66$ 
DM FILTER SET: DM-14A

IMPACTOR ID: ACI-931

LOCATION: Between Laser core hole and DCT, near wall

RUN TIME (min): 256
0.000709

0.000465

0.000431

0.000347

0.000445

0.00043

0.000388

0.000425

0.000395

0.001318
SAMPLE DATE: 04/20/88

CORE HOLE: AC-2

TOTAL WEIGHT GAIN (g): 0.005353 (mg): 5.353

MASS MEDIAN AERODYNAMIC DIAMETER $(\mu \mathrm{m}): 1.16$

STANDARD DEVIATION: 6.51

IMPACTOR CONCENTRATION $\left(\mathrm{mg} / \mathrm{m}^{3}\right): .55$

DM FILTER SET: DM-15A

SAMPLE DATE: $04 / 21 / 88$

IMPACTOR ID: ACI-1002

LOCATION: Center of Laser Drift, approximately $15 \mathrm{ft}$ from face

RUN TIME (min): 192

PRE-SEPARATOR
STAGE 0
STAGE 1
STAGE 2
STAGE 3
STAGE 4
STAGE 5
STAGE 6
STAGE 7
FINAL

0.0005
0.001052
0.00027
0.00018
0.000205
0.000188
0.000256
0.000192
0.000286
0.00037

0.5

1.052

0.27

0.18

0.205

0.188

0.256

0.192

0.286

0.37

TOTAL WEIGHT GAIN (g): 0.003499 (mg): 3.499

MASS MEDIAN AERODYNAMIC DIAMETER $(\mu \mathrm{m}): 0.965$

STANDARD DEVIATION: 9.86

IMPACTOR CONCENTRATION $\left(\mathrm{mg} / \mathrm{m}^{3}\right): .55$ 


\section{APPENDIX E \\ NOTEBOOKS AND LOGBOOKS}

Data in this report can be found in the following notebooks and logbook.

\section{NOTEBOOKS}

TWS-HSE5-07-87-006

TWS-HSE5-12-87-007

TWS-HSE5-12-8?-008

TWS-HSE5-12-87-009

TWS-HSE5-12-87-010

\section{LOGBOOKS}

TWS-HSE5-06-88-001

The activities that this report documents are assigned a Quality Assurance Level of II because they have direct bearing on the health of workers at the prototype test and Yucca Mountain sites. 


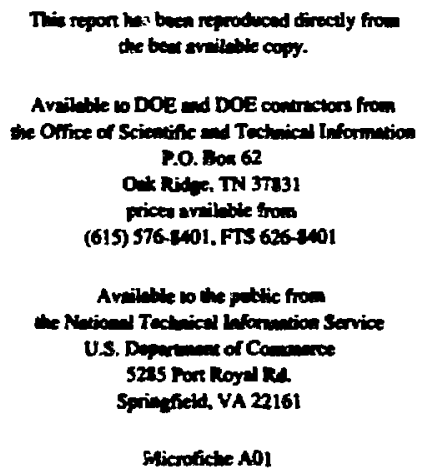

Shicoficte AOI

\begin{tabular}{|c|c|}
\hline Fer & $\begin{array}{l}\text { Nms } \\
\text { mios colo }\end{array}$ \\
\hline $001-023$ & 202 \\
\hline $025-\infty$ & $\mathbf{A m}$ \\
\hline OS1-075 & MaA \\
\hline $076-100$ & Aos \\
\hline $101-125$ & ANS \\
\hline $12-150$ & $M$ \\
\hline
\end{tabular}

NTt5

Fuenere riat Cole

15!-175

$17-200$

201-225

$20-200$

251-275

27c-300

Nos
AO
A10
A11
A12
A13

A10

A11

A13
Nms

\begin{tabular}{|c|c|}
\hline$\underline{B}=\mathrm{R}=$ & Price Cole \\
\hline $301-325$ & Ald \\
\hline $326-350$ & Als \\
\hline $391-375$ & Al6 \\
\hline $376-100$ & A17 \\
\hline $401-425$ & AlE \\
\hline $426-450$ & A19 \\
\hline
\end{tabular}

Nins

IeRer rice Cole

$451-475$

476-500

501-525

526-50

391-575

576-100

(1)

An

A21

A2

42

A24

As:

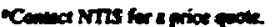

